\title{
VALORIZATION OF EUTERPE OLERACEA MART. (açaí) BY- PRODUCT: CHARACTERIZATION, EXTRACTION AND FORMULATION.
}

Presentada por Rafaella Theodoro Buratto para optar al grado de Doctora por la Universidad de Valladolid

Dirigida por:

Dr.- Ing. Ángel Martín Martínez

Prof. Dr María José Cocero 


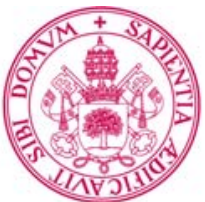

Universidad deValladolid 


\section{Content}

Title

Page

Abstract

05

Introduction

Objectives

Chapter1

Characterization of Euterpe Oleracea Mart. (Açaí) Pulp and its Residual

Fractions: Extractives and Structural Sugar Composition

\section{Chapter2}

Extraction of Polyphenols from Euterpe Oleracea Mart. (açaí) Wastes

\section{Chapter3}

Formulation by Impregnation of Euterpe Oleracea Mart. (Açaí) Residue

Extracts in Silica-Aerogel

\section{Chapter4}

Co-precipitation of Açaí Pulp and seeds extract by Supercritical

Antisolvent technology

Final Conclusions

Resumen

Acknowledgements

About the Author 

Abstract 
Açaí is the popular name of Euterpe oleracea Mart. The fruit is original from the amazon rain forest, and the industry interest on it is focused on its pulp. This pulp obtained from açaí is commercialized as freeze-pulp, pure or mixed with other fruit extracts. However, during the pulp processing, a large amount of by-products is generated, including seeds, slurry (skins and fibers retained during the filtration), and on many occasions even the pulp which is susceptible to many different diseases (such as Chagas).

The pulp has been applied as treatment and prevention of some diseases, including dementia, Alzheimer, Parkinson, atherosclerosis, obesity, and, gastritis because açaí extract contains antioxidant and anti-inflammatory agents. The benefits of $E$. Oleracea extract are associated with the presence of polyphenols, secondary metabolites of plants, especially related to flavonoids (a class of polyphenols), which include volutein, luteolin, apigenin, and orientin, present in the extract.

In this thesis, the application of acai processing non-edible byproducts in cosmetic products is studied, valorizing in this way the byproduct generated in the industrial production of edible pulp of açaí. The raw material was obtained from ObidosPA-Brazil. The seeds were milled and dried, and, the pulp was lyophilized. In order to achieve this objective, a complete characterization of the residual material was necessary. In chapter 1, the composition of all fraction of açaí by-products (pulp, seeds, and slurry) is studied. The content of lipids, extractives, sugars, ashes, fixed minerals, fibbers, proteins, and, the phytochemical composition is determined; the same methodology was applied for each fraction. The amount of extractive was determined by extraction with soxhlet apparatus. The results showed that extractives represent a total of $68.1 \%$ on pulp, $17.5 \%$ on seeds, and $4.9 \%$ on the slurry fraction. The pulp is the fraction that contains the highest proportion of extractives, with an oil content of $43.1 \%$, in which $23.6 \%$ are aqueous extractives, $3.4 \%$ are ethanol extractives, and the remaining compounds are hexane extractives. The pulp-oil contained important fatty acids such as oleic acid (58.5\%), linoleic acid (22.3\%), palmitic acid (11.4\%) and stearic acid (4.1\%). In the 
aqueous extract, the seeds have shown $13.1 \%$ of extractives on dry mass, and, slurry $3.4 \%$.

A short study about the intensification extraction is provided in chapter 2 . Procedures such as microwave technology were chosen, as intensification technique, achieving higher extraction temperature in few seconds, reducing the extraction time, improving the quality of extracts, and avoiding the unwanted degradation of the product of interest. Macerations is applied as an extraction technique, and microwave has been studied as an intensification technique. Applying MAE (300W, 30seconds) as a pretreatment of slurry material promoted an increase of TPC values, from $269 \mathrm{mgGAE} / \mathrm{L}$ to $735 \mathrm{mgGAE} / \mathrm{L}$, after 30 minutes of extraction. Extraction of seeds was not affected by MAE (300W, 30seconds) pre-treatment. Nevertheless, seeds show higher potential as polyphenols source than slurry, in terms of TPC values $(29057 \mathrm{mg} \mathrm{GAE} / \mathrm{L}$ in the case of seeds compared to $735 \mathrm{mgGAE} / \mathrm{L}$ in the slurry, at the same extraction conditions).

Formulation procedures were selected by their ability to preserve extracts for future applications. Two different processes were studied: impregnation in aerogels and encapsulation in polymers by supercritical antisolvent process. Both formulation procedures adopted produce low amounts of residus, low toxicity or harmful residues in the final material, and are compatible with such sensitive natural products as the active compounds obtained in the extracts. At Chapter 3, Silica aerogel, obtained by sol-gel process and dried by supercritical technology, was used to perform the studied by direct and indirectly impregnation. From each of the three fractions of by-product, pulp, seeds, and slurry two different extracts were obtained: an oil fraction obtained by Soxhlet extraction, and a polyphenolic-rich extract obtained by Pressurized Microwave-Assisted Extraction. Results showed an impregnation yield of $58.6 \%$ when the pulp oil was impregnated in silica aerogel, and it was air-dried (surface area of $0.77 \mathrm{~m}^{2} / \mathrm{g}$ ), while the impregnation yield decreased to $15.3 \%$, with supercritical drying method (surface area of $823 \mathrm{~m}^{2} / \mathrm{g}$ ). These results indicated a loss of oil by extraction during the supercritical drying. With pulp extract, the best result was obtained using indirect wet impregnation and supercritical drying, with a yield of $16.4 \%$ of impregnation. The material resulted is proposed as a pilling agent for cosmetics applications.

Another type of formulation is proposed in chapter 4, in which the phenolic extract obtained from pulp and seeds were co-precipitated by supercritical antisolvent (SAS) process with PVP and Pluronic F 127. The extractives were obtained by PMAE using Ethanol/water (50\%) acidified as a solvent; microwave works at constant potency 
of $300 \mathrm{~W}$ until achieve $1.5 \mathrm{bar}$ of pressure. The best results were observed when ethanol was applied as a solvent and PVP as polymer. Different ratios of seeds-extract and PVP were processed, obtaining good results with proportions of 2:1, 1:1, and 1:2. Pulp extract and PVP were successfully processed on ratios of 2:1, and 1:1. The morphology was studied by Scanning Electron Microscope (SEM) images. It was observed that the SAS process promoted the particle seeds-extract micronization. The solvation ratio changed the final particle size. The best relation between mass/solvent found was $2.5 \mathrm{~g} / \mathrm{L}$, at this solvation ratio it was possible to obtain a co-precipitated material, better-distributed, less exposed areas, and small particle size. The FTIR analysis of both formulated materials showed, in both cases, characteristic peaks of the source material and extract. 



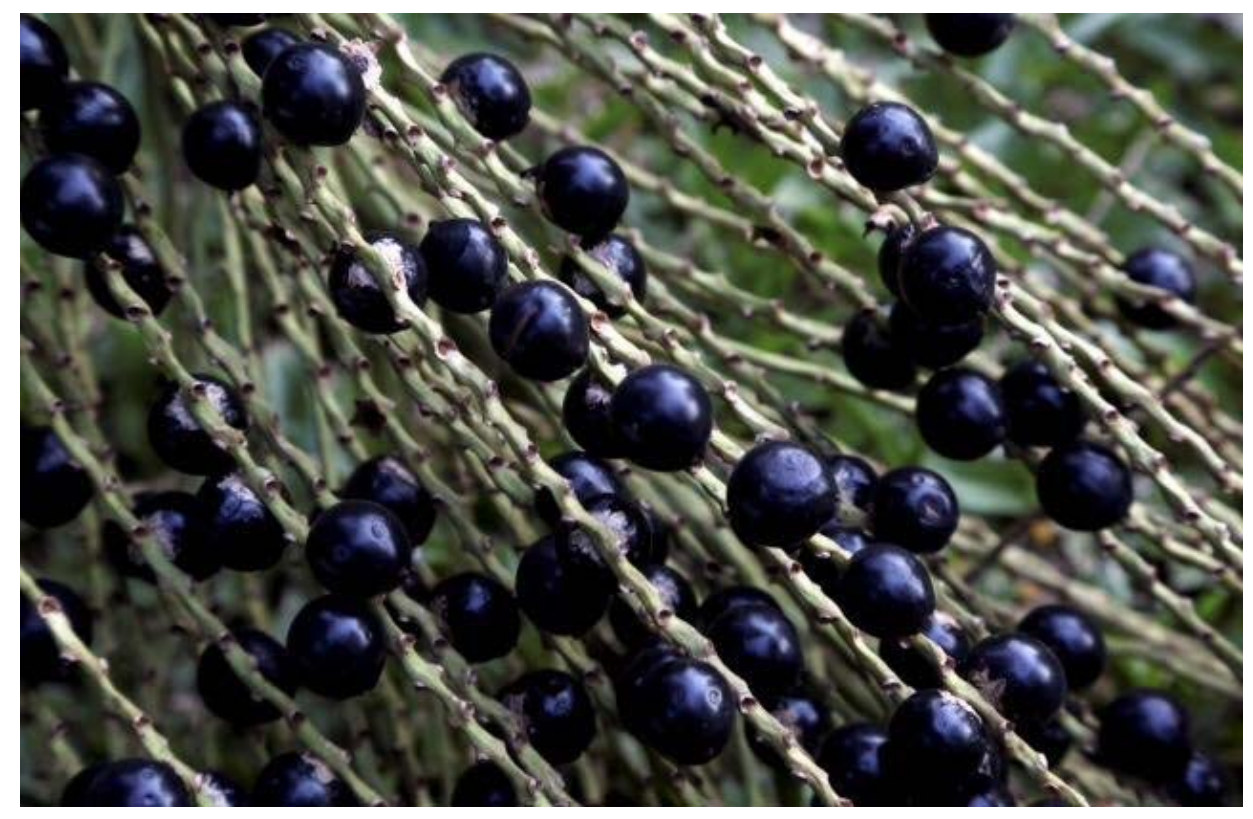

Euterpe Oleracea Mart.

"Many years ago, the chief of an indigenous tribe which was in difficulty during the worst food scarcity in the region, fed by the fearing of tribe death, saw himself obligated to give the hardest order ever 'the sacrifice of all children in the tribe', including his own grandson, son of Iaça. Iaça could not understand the decision took by her father, crying day by day. It a night, Iaça listened to her son crying and followed the sound. The sound came from a palm tree inside the forest. Iaça recognized her son's face on the tree's trunk. She spent the night there, and in the morning, she was found dead hugging the palm. Iaça was still smiling, and her open eyes gazed at those e-purple and small fruits at the top of the palm. The chief could not hold his pain when he gave the order to tribe take and crush those fruits, destroying them. What a surprise when the request was completed, and they observed that it was possible to produce a mass to feed the tribe and amend its hunger. The fruit became the primary food source for that tribe. The chief, in honor of his daughter, inverted her name, calling the fruit as Açaí”.

(The Legend of Açaí - Brazilian Popular Folklore) 


\section{Introduction}

Euterpe Oleracea mart. (E. Oleracea) is a black-purple berry popularly known as açaí. The name came from the Portuguese adaptation of the Tupian word yasaí which can be translated as fruit that cries. The fruit grows in the E. Oleracea Palm typically found in Amazon Rainforest. The fruit is mainly used to obtain the pulp, consumed as a typical dish in the northern region of Brazil. The fruit is famous because it presents a high content of bioactive compounds (such as important fatty acids, polyphenols, anthocyanin, flavonoids, tannins, among others) which the frequent consume promotes uncountable health benefits.

Açaí is rarely consumed as fresh fruit, requiring an industrial process where the pulp is extracted, filtrated and frozen before its commercialization. In the process to obtain the pulp, around $16 \%$ of the whole fruit, generates a large amount of residue which is composed of seeds, fibers, and skin, implying a huge environmental problem.

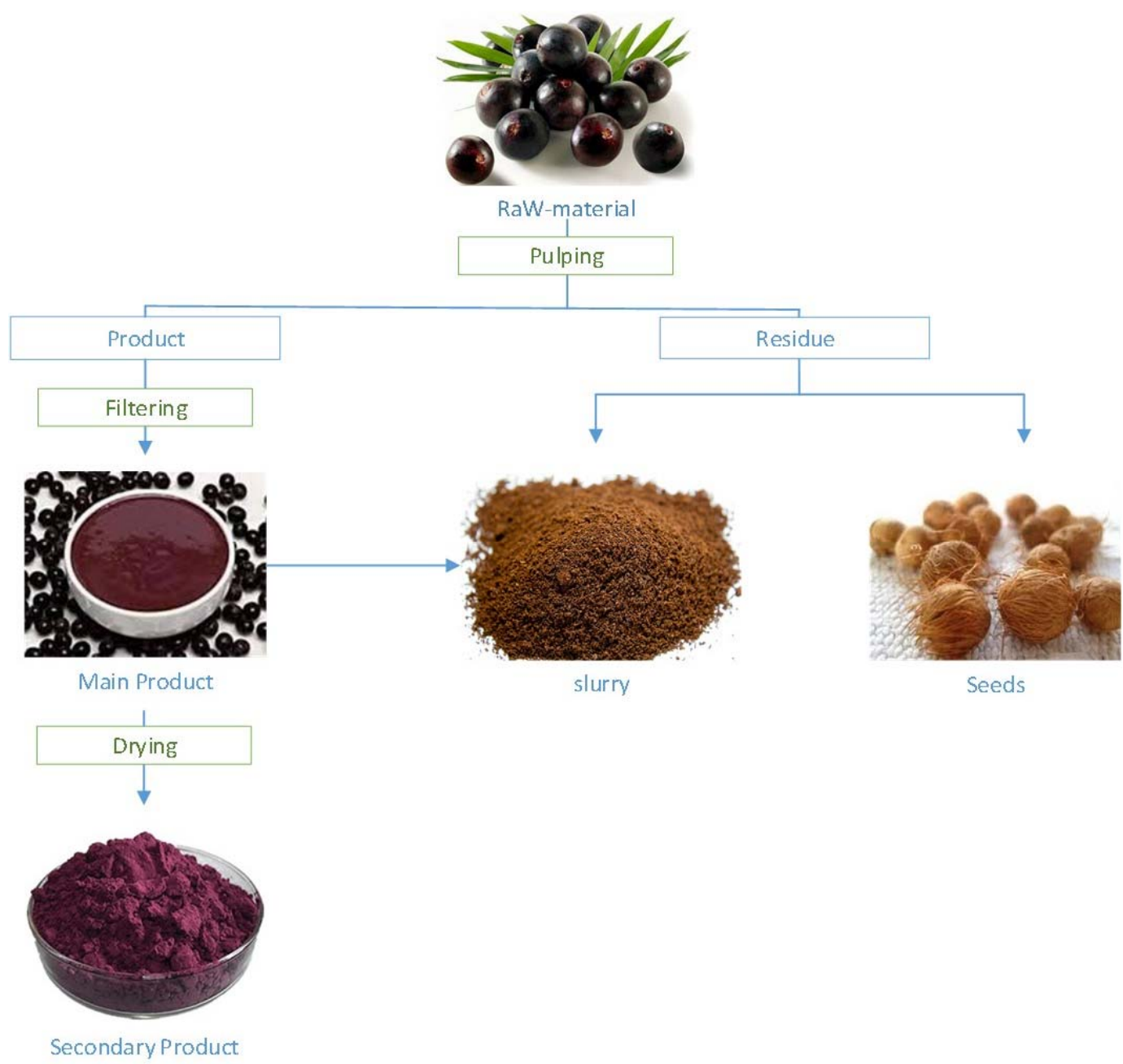

Figure 1 - Scheme of Açaí processing industry 


\subsection{E. Oleracea overview}

Among the years, the extract of E. Oleracea has been studied with a different focus based on its properties. The main extracts features considered came from the bioactive molecules present on it, more specifically the polyphenols. These substances are secondary metabolites of plants and responsible for its protection against infections caused by pathogens and abiotic stress produced by environmental temperaturechanges, luminosity-level, and UV-light exposition. There are also some polyphenols which are responsible for the plant pigmentation, being responsible for attracting pollinizers and seeds-dispersal agents.

The E. Oleracea extract is rich in polyphenols, the specific composition changes depend on the planting-area, water and nutrients availability, harvests period, among many other factors. Many studies support that açaí extract acts as antioxidant and antiinflammatory agents, influencing in other process and presenting many different functions, such as anti-arthritic, antimalarial, analgesic, mitochondrial calcium homeostasis modulator, dysfunctional-autophagy on brain cells, neuroprotector, antigastrointestinal-inflammation, and oxidative stress [1-10].

In this way, açai extract has been proposed and studied as treatment and prevention for many different diseases such as dementia, Alzheimer, Parkinson, atherosclerosis, obesity, gastritis, peptic ulcer [1,2,11-14]. The benefits of E. Oleracea extract are frequently associated with flavonoids (a type of polyphenols) such as volutein, luteolin, apigenin, and orientin, present in the extract and also studied individually [11,15-23].

\subsection{Extraction Methods}

An intensification extraction process is proposed using microwave energy to improve the release of organic material from innate cells (sewage sludge, microalgae, and bagasse), thus obtaining improved kinetical method after a short pretreatment step up to the boiling temperature, following the standard procedure. In industrial processes, the natural matrices that are linked to the substance of interest may have an intracellular location. To facilitate the accessibility of the product in question, the innate cells have to be damaged in a pre-treatment step. This primary stage of the processes is often recognized as the limiting step of kinetic rate, leading to a slow process. Longer running time gives traditional methods low recovery efficiency and high operating costs. 
The extraction by microwave radiation can improve the rupture of the cellular wall of materials of high humidity. This is due to the rapid heating and evaporation of intracellular water and the pressure gradient that leads to the damage of the cell wall. Although the use of microwave technology in analytical processes can lead to faster and more economical procedures, the electric energy applied to transfer microwave to the sample can increase the costs of operation when considering an industrial-scale application. For this reason, microwave pretreatment, in which microwaves are only applied during a short time before applying a conventional extraction, may be an alternative to this drawback. [24].

This additional step would not replace the existing process but may modify the cell structure to facilitate the traditional method in continuation, thereby enhancing the conventional kinetics of the process. Moreover, decrease the time required to extract bioactive substances helps to improve the extraction of interest compounds avoiding the degradation promoted by exposition to mild or high temperatures [25].

\subsection{Formulation in Aerogels system}

The incorporation of active substances into a matrix by impregnation has been applied to protect and preserve valuable compounds of free radicals, oxygen or UV, and for controlled drug release or improvement of bioavailability [26]. Aerogels are presented as a suitable material to protect the compound, due to its large specific surface area and open porosity, which improves the impregnation of active compounds and therefore allows a high load of them [27]. Aerogels are obtained from wet-gels (alcohol or hydro-gels) by sol-gel procedure method, using an appropriate drying technology it is possible to dry the wet-gels avoiding the phenomenon of pore collapse and keeping the porous texture of the wet material intact. The supercritical CO2-drying technique is a suitable method for drying the gels, once it is able to solubilize the solvent into the gel keeping the gel-structure and avoiding excessive solvent-residue. Moreover, the process is convenient for natural products because it is not necessary to apply excessive heat, which could promote degradation, being possible to work at $40^{\circ} \mathrm{C}$ [28].

The resulting aerogel materials may also meet the performance criteria for other emerging markets, such as the cosmetic, food, and biotechnology industry [29-31]. Among all aerogels, silica ones have become quite popular because they have a wide variety of useful properties, such as high porosity (around 98\%), high specific surface area $\left(1200 \mathrm{~m}^{2} / \mathrm{g}\right)$, low thermal conductivity, among others [26]. Also, $\mathrm{SiO}_{2}$ aerogels have 
some physical and ecological advantages such as non-toxic, non-flammable, and easy to remove, being competitive and compared to other materials on the market [32]. More recently, the use of silica aerogels has been focused on the pharmaceutical field, as a support material in the formulation and rapid release of pharmaceutical compounds and the field of biomedicine $[26,33,34]$.

\subsection{Formulation by SAS technique}

The encapsulation of active compounds is a way to protect them against early degradation, increasing the solubility of poorly water-soluble substances, and facilitate its application to industrial production. One method for bioactive protection is to insert it into a polymeric matrix, creating a polymeric membrane around the particle to isolate the core from the external environment [35]. Supercritical Anti-Solvent (SAS) encapsulation is a very versatile process for the processing of various natural and pharmaceutical compounds, with reasonable control of particle properties, and without degradation or contamination of the final product [27,36]. For the SAS process, the particle for encapsulation and the encapsulating agent are solubilized in an organic solvent, in which they have soluble-affinity. Then, the solution is pumped into a precipitator pressurized and containing $\mathrm{CO}_{2}$ under supercritical condition. The prepared solution and $\mathrm{CO}_{2}$ gas are inserted into the precipitator at the same time, generating a spray effect. At this moment, the solvent in the solution is solubilized by supercritical $\mathrm{CO}_{2}$, and the precipitation of the particle occurs (previously in the solution) [37]. Besides, as already indicated, it is possible to work with moderate temperatures, lower than $50{ }^{\circ} \mathrm{C}$, offering better conditions to work with sensible substances as natural products [27].

\section{References}

[1] A.G. Schauss, The Effect of Acai (Euterpe spp.) Fruit Pulp on Brain Health and Performance, in: Bioact. Nutraceuticals Diet. Suppl. Neurol. Brain Dis. Prev. Ther., 2014: pp. 179-186.

[2] E. Sangiovanni, M. Fumagalli, M. Dell'Agli, Berries: Gastrointestinal Protection 
against Oxidative Stress and Inflammation, in: Gastrointest. Tissue - Oxidative Stress Diet. Antioxidants, 2017: pp. 243-258.

[3] A.Y. Odendaal, A.G. Schauss, Potent Antioxidant and Anti-Inflammatory Flavonoids in the Nutrient-Rich Amazonian Palm Fruit, Açaí (Euterpe spp.), in: Polyphenols Hum. Heal. Dis., 2014: pp. 219-239.

[4] S.L. Laev, N.F. Salakhutdinov, Anti-arthritic agents: progress and potential, Bioorg. Med. Chem. 23 (2015) 3059-3080.

[5] G. Bourdy, S.J. DeWalt, L.R. Chávez De Michel, A. Roca, E. Deharo, V. Muñoz, L. Balderrama, C. Quenevo, A. Gimenez, Medicinal plants uses of the Tacana, an Amazonian Bolivian ethnic group, J. Ethnopharmacol. 70 (2000) 87-109.

[6] L. Ruiz, L. Ruiz, M. MacO, M. Cobos, A.L. Gutierrez-Choquevilca, V. Roumy, Plants used by native Amazonian groups from the Nanay River (Peru) for the treatment of malaria, J. Ethnopharmacol. 133 (2011) 917-921.

[7] S.M. Poulose, D.R. Fisher, J. Larson, D.F. Bielinski, A.M. Rimando, A.N. Carey, A.G. Schauss, B. Shukitt-Hale, Anthocyanin-rich açai (Euterpe oleracea Mart.) fruit pulp fractions attenuate inflammatory stress signaling in mouse brain BV-2 microglial cells, J. Agric. Food Chem. 60 (2012) 1084-1093.

[8] S.M. Poulose, D.R. Fisher, D.F. Bielinski, S.M. Gomes, A.M. Rimando, A.G. Schauss, B. Shukitt-Hale, Restoration of stressor-induced calcium dysregulation and autophagy inhibition by polyphenol-rich acai (Euterpe spp.) fruit pulp extracts in rodent brain cells invitro, Nutrition. 30 (2014) 853-862.

[9] A.K. Machado, A.C. Andreazza, T.M. Da Silva, A.A. Boligon, V. Do Nascimento, G. Scola, A. Duong, F.C. Cadoná, E.E. Ribeiro, I.B.M. Da Cruz, Neuroprotective Effects of Açaí (Euterpe oleracea Mart.) against Rotenone in Vitro Exposure, Oxid. Med. Cell. Longev. (2016) 1-14.

[10] D.Y.S. Wong, I.F. Musgrave, B.S. Harvey, S.D. Smid, Açaí (Euterpe oleraceae Mart.) berry extract exerts neuroprotective effects against $\beta$-amyloid exposure in vitro, Neurosci. Lett. 556 (2013) 221-226.

[11] S. Hirai, N. Takahashi, T. Goto, S. Lin, T. Uemura, R. Yu, T. Kawada, Functional food targeting the regulation of obesity-induced inflammatory responses and pathologies, Mediators Inflamm. (2010) 1-8.

[12] L. Badimon, G. Vilahur, T. Padro, Nutraceuticals and atherosclerosis: Human trials, Cardiovasc. Ther. 28 (2010) 202-215.

[13] J. Oleszczuk, L. Oleszczuk, A.K. Siwicki, Biological effects of conjugated 
linoleic acids supplementation, 15 (2012) 403-408.

[14] A. Bhattacharyya, R. Chattopadhyay, S. Mitra, S.E. Crowe, Oxidative Stress: An Essential Factor in the Pathogenesis of Gastrointestinal Mucosal Diseases, Physiol. Rev. 94 (2014) 329-354.

[15] J. Xiao, E. Capanoglu, A.R. Jassbi, A. Miron, Advance on the Flavonoid Cglycosides and Health Benefits, Crit. Rev. Food Sci. Nutr. 56 (2016) S29-S45.

[16] S.F. Nabavi, N. Braidy, O. Gortzi, E. Sobarzo-Sanchez, M. Daglia, K. SkalickaWoźniak, S.M. Nabavi, Luteolin as an anti-inflammatory and neuroprotective agent: A brief review, Brain Res. Bull. 119 (2015) 1-11.

[17] L. Zhao, J.L. Wang, R. Liu, X.X. Li, J.F. Li, L. Zhang, Neuroprotective, antiamyloidogenic and neurotrophic effects of apigenin in an Alzheimer's disease mouse model, Molecules. 18 (2013) 9949-9965.

[18] R. Balez, N. Steiner, M. Engel, S.S. Muñoz, J.S. Lum, Y. Wu, D. Wang, P. Vallotton, P. Sachdev, M. O’Connor, K. Sidhu, G. Münch, L. Ooi, Neuroprotective effects of apigenin against inflammation, neuronal excitability and apoptosis in an induced pluripotent stem cell model of Alzheimer's disease, Sci. Rep. 6 (2016) 1-16.

[19] S.P. Patil, P.D. Jain, J.S. Sancheti, P.J. Ghumatkar, R. Tambe, S. Sathaye, Neuroprotective and neurotrophic effects of Apigenin and Luteolin in MPTP induced parkinsonism in mice, Neuropharmacology. 86 (2014) 192-202.

[20] M. Cai, Y. Ma, W. Zhang, S. Wang, Y. Wang, L. Tian, Z. Peng, H. Wang, T. Qingrong, Apigenin-7-O- $\beta$-D-(-6'-p-coumaroyl)-glucopyranoside treatment elicits neuroprotective effect against experimental ischemic stroke, Int. J. Biol. Sci. 12 (2016) 42-52.

[21] K. Yamagata, T. Kitazawa, M. Shinoda, C. Tagawa, M. Chino, H. Matsufuji, Stroke status evoked adhesion molecule genetic alterations in astrocytes isolated from stroke-prone spontaneously hypertensive rats and the apigenin inhibition of their expression, Stroke Res. Treat. (2009) 1-11.

[22] C. Xie, J. Kang, Z. Li, A.G. Schauss, T.M. Badger, S. Nagarajan, T. Wu, X. Wu, The açaí flavonoid velutin is a potent anti-inflammatory agent: Blockade of LPSmediated TNF- $\alpha$ and IL- 6 production through inhibiting NF- $\kappa$ B activation and MAPK pathway, J. Nutr. Biochem. 23 (2012) 1184-1191.

[23] X. Wu, A.G. Schauss, Mitigation of inflammation with foods, J. Agric. Food Chem. 60 (2012) 6703-6717. 
[24] K. Sólyom, S. Kraus, R.B. Mato, V. Gaukel, H.P. Schuchmann, M.J. Cocero, Dielectric properties of grape marc: Effect of temperature, moisture content and sample preparation method, J. Food Eng. 119 (2013) 33-39.

[25] K. Sólyom, R. Solá, M.J. Cocero, R.B. Mato, Thermal degradation of grape marc polyphenols, Food Chem. 159 (2014) 361-366.

[26] E.G.H. Durán, Formulación de productos con alto contenido en polifenoles a partir de subproductos obtenidos de la valorización del Açaí, University of valladolid, 2018.

[27] A. Martín, M.J. Cocero, Micronization processes with supercritical fluids: Fundamentals and mechanisms, Adv. Drug Deliv. Rev. 60 (2008) 339-350.

[28] Z. Novak, Ž. Knez, Diffusion of methanol-liquid CO2 and methanol-supercritical CO2 in silica aerogels, J. Non. Cryst. Solids. 221 (1997) 163-169.

[29] M. Alnaief, S. Antonyuk, C.M. Hentzschel, C.S. Leopold, S. Heinrich, I. Smirnova, A novel process for coating of silica aerogel microspheres for controlled drug release applications, Microporous Mesoporous Mater. 160 (2012) $167-173$.

[30] I. Smirnova, S. Suttiruengwong, W. Arlt, Feasibility study of hydrophilic and hydrophobic silica aerogels as drug delivery systems, J. Non. Cryst. Solids. 350 (2004) 54-60.

[31] C.A. García-González, M. Alnaief, I. Smirnova, Polysaccharide-based aerogels Promising biodegradable carriers for drug delivery systems, Carbohydr. Polym. 86 (2011) 1425-1438.

[32] J.L. Gurav, I.K. Jung, H.H. Park, E.S. Kang, D.Y. Nadargi, Silica aerogel: Synthesis and applications, J. Nanomater. 2010 (2010) 1-11.

[33] H. Maleki, L. Durães, C.A. García-González, P. del Gaudio, A. Portugal, M. Mahmoudi, Synthesis and biomedical applications of aerogels: Possibilities and challenges, Adv. Colloid Interface Sci. 236 (2016) 1-27.

[34] R.P. Patel, N.S. Purohit, A.M. Suthar, An overview of silica aerogels, Int. J. ChemTech Res. 1 (2009) 1052-1057.

[35] M.J. Cocero, Á. Martín, F. Mattea, S. Varona, Encapsulation and co-precipitation processes with supercritical fluids: Fundamentals and applications, J. Supercrit. Fluids. 47 (2009) 546-555.

[36] D.T. Santos, M.A.A. Meireles, Micronization and encapsulation of functional pigments using supercritical carbon dioxide, J. Food Process Eng. 36 (2013) 36- 
49.

[37] A. Visentin, S. Rodríguez-Rojo, A. Navarrete, D. Maestri, M.J. Cocero, Precipitation and encapsulation of rosemary antioxidants by supercritical antisolvent process, J. Food Eng. 109 (2012) 9-15. 
Objectives 
This thesis aimed to study the valorization of the non-edible products of Euterpe Oleracea Mart produced as by-products of the industrial processing of this fruit. Hence, this study consisted of the following specific objectives:

(I) To characterize the residues of E. Oleracea, obtained from industry (pulp not able to consume -, seeds, and slurry) as biomass and potential phytochemical source, determining the content of lipid, extractives (according their total polyphenol, anthocyanin, flavonoid and tannins content, and, antioxidant activity by ORAC value), structural sugar composition (cellulose, hemicellulose and lignin), ashes, fixed mineral, protein, and the phytochemical composition of each residual fraction applying the same methodology.

(II) To study the extraction of bioactive compounds by traditional Soxhlet method and maceration. Also, to study the extraction intensification process by applying microwave energy and microwave energy combined with pressurization. To evaluate the benefits of treatment in extraction kinetics as well as differences in terms of extraction yield, total polyphenols content (TPC), total anthocyanin contents (TAC), and antioxidant activity by oxygen radical absorbance capacity (ORAC).

(III) To formulate the material obtained from the extraction of each fraction of the E. Oleracea by-product (skin, seed, and pulp) facilitating their applications to the formulation of secondary products such as creams and dyes. Moreover, the formulation aimed to protect the active ingredients from involuntary degradation, which would reduce the antioxidant activity of the extract. Specifically, to evaluate two methods:

$>$ The impregnation of extracts in silica aerogels by a direct and indirect method, and applying supercritical $\mathrm{CO}_{2}$-drying technology in the production of aerogels.

$>$ The encapsulation of seeds and pulp extract in a polymeric matrix by Supercritical anti-solvent (SAS) process. 
The objectives of this thesis are developed in 4 chapters, which are presented as follows:

Chapter 1 presents the characterization of Euterpe Oleracea Mart. (Açaí) pulp and its by-products fractions, determining the extractives (according to their Total polyphenol, anthocyanin, flavonoid and tannins content, and, Antioxidant activity by ORAC value), and structural sugar composition.

Chapter 2 presents the extraction of polyphenols from Euterpe Oleracea Mart. (açaí) non-edible products, using as studding material seeds, slurry, and pulp by maceration process, applying MAE and PMAE as intensification pre-treatment extraction to assess the effects on material and its application in the valorization E. Oleracea by-products.

* Chapter 3 presents the formulation of extracts obtained by its impregnation in Silica-Aerogel.

Chapter 4 presents the formulation of extracts obtained for its protection, using Supercritical antisolvent method to promote the coprecipitation of extracts and polymer. 
Characterization of Euterpe Oleracea Mart. (Açaí) Pulp and its Residual Fractions: Extractives and Structural Sugar Composition 
Chapter 1 


\begin{abstract}
Açaí (Euterpe Oleracea Mart.) is a black-purple berry typically found in Amazon Rainforest. E. Oleracea product is a natural phytochemical source, which shows a high content of polyphenols and flavonoids. It also presents remarkable properties as antioxidant and natural dye. This study presents a characterization of all residual fractions of Euterpe Oleracea mart. (açaí) and assesses its potential as biomass and phytochemicals source, determining the content of lipids, extractives, sugars, ashes, fixed minerals, fibbers, proteins, and, the phytochemical composition of each residual fraction by the same methodology. The oil content represents $43.1 \%$ of the dry pulp weight, in which important fatty acids such as oleic acid (58.5\%), linoleic acid (22.3\%), palmitic acid (11.4\%) and stearic acid (4.1\%) were identified. The pulp and seeds showed potential as antioxidant agent with ORAC (oxygen radical absorbance capacity) values of 89760 and $65263 \mu \mathrm{mol}$ TE/100gDM. Cellulose (18\%), hemicellulose (20\%) and lignin (36\%) are the main components of the slurry fraction (fibres and skin from pulp filtration), 18\%, 20\%, and, 36\%, respectively, whereas, in seeds, the main component found was hemicellulose (up to 48\%).
\end{abstract}

Keywords. Euterpe Oleracea Mart.; açaí by-products; açaí seeds; açaí-Oil. 


\section{Introduction}

Açaí is a black-purple berry obtained from Euterpe Oleracea Palm plant, wieldy found in northern South America. The palm was first described by Karl Friedrich Philipp von Martius, in the second volume of Historia Naturalis Palmarum (1824). Its name comes from the Brazilian Portuguese, in an adaptation of the Tupian word yasa'I - fruit that cries [1]. In according to Cronquist order (1981), E. Oleracea is classified as Magnoliophyta (Class: Liliopsida; Subclass: Arecidae; Order: Arecales; Family: Arecaceae; Subfamily: Arecoidae - Euterpe Oleracea Mart.). E. Oleracea Palm grows better in waterlogged or humid areas. Approximately six trunks compose this tree, which can be as high as 20 meters. In E. Oleracea palm, berries grow in bunches and show a spherical and small shape, and fruits and seeds do not have a big difference in terms of size (around 1.2 and $1.5 \mathrm{~cm}$ of diameter). The fruit can be divided between skin, pulp and seed; Inside, the seed is composed of fibers and an internal content [2].

Açaí (E. Oleracea Mart.) is mainly used to produce Açaí pulp, typically consumed in the north of Brazil, and now also known due to its properties as an antioxidant and its high bioactive content. Just in Pará (Brazilian state) 180 thousand tons of açaí pulp is consumed per year [3]. During the season, a processing company produces a large amount of residue per day because just a small part of the fruit is eatable, around $5-15 \%$, depending on the origin and maturity of the fruit. Seeds represent around $83 \%$ of total fruit [4].

During the pulping process, the pulp is separated from seeds (first fraction of residue), in a second step pulp is clarified by a filter where slurry (second fraction of waste) is removed, and finally, the pulp is measured to certify its safety for consumption. When a pulp batch is considered inappropriate for consumption, the batch is destined to residue in its totality (third fraction of waste). All residual fractions can be observed in Figure 1.

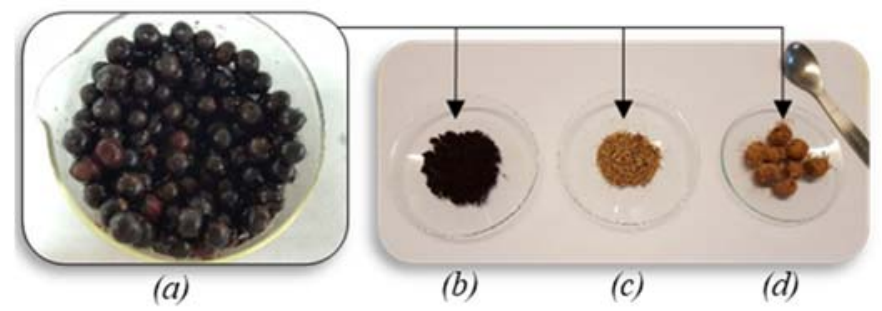

Figure 1 - (a) E. Oleracea (Açaí) in nature; (b) dry-pulp; (c) dry-slurry; and, (d) seed. 
The composition of açaí is variable and it can change depending on environmental conditions such as the amount of rain, harvest period, soil $\mathrm{pH}$ and composition, or genetic variation, among others. Seeds are composed by cellulose and hemicellulose (63-81\%), proteins (5-6\%), lipids (2-3\%), and, minerals (2-6\%) [5]. Polyphenols in the plant mainly comprise protocatechuic acid, different dimers of procyanidin, and epicatechin [6]. Lipids present in the plant include fatty acids, phospholipids, sterols, sphingolipids, terpenes, and others [7].

In E. Oleracea fruit, oily content is an important fraction of the material, representing around $45 \%$ of dry mass material [8]. On fruit, fatty acids can appear free as monomers or linked as triglycerides, and they are composed by different unsaturated fatty acids, mainly oleic (60\%), palmitic (20-22\%), linoleic (12\%), palmitoleic (2-6\%), and stearic acid (2\%) [9] [5] [10]. The structure of the main fatty acids present in $E$. Oleracea extract are represented in Figure 2. The main interest of oil composition rests on the presence of long-chain, unsaturation such as omega-9 in oleic acids, and essential fatty acids such as stearic acid. Moreover, the oil has antioxidant potential provided by some oil-soluble polyphenols. The main therapeutic property of this oil is the antidiarrheal effect [11].
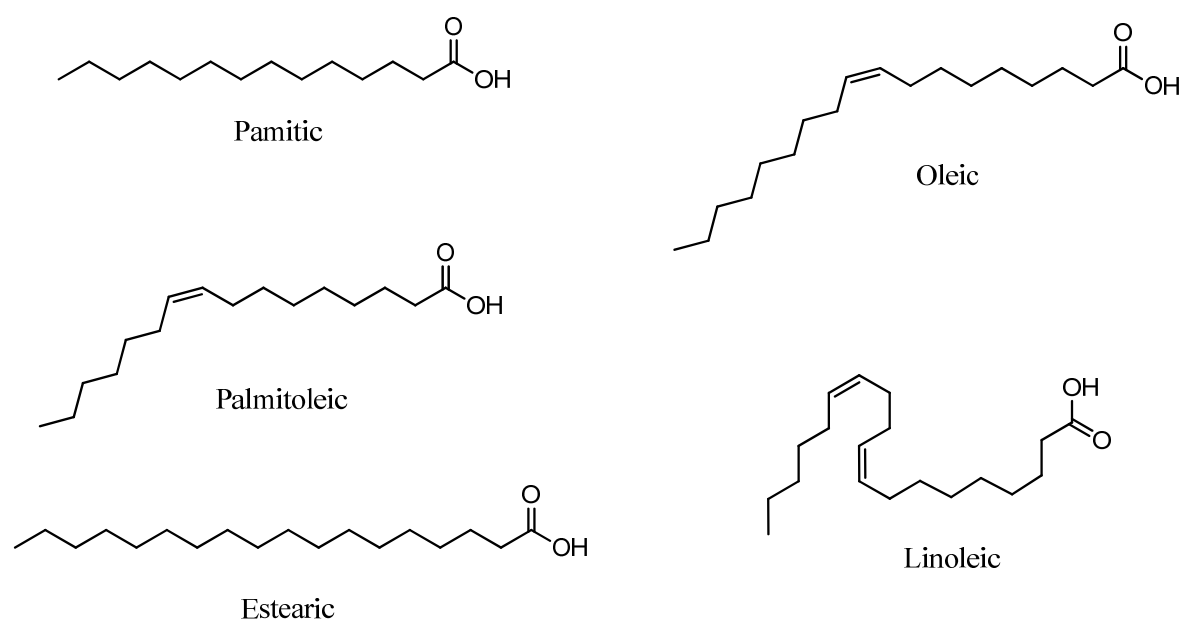

Figure 2 - Structure of fatty acid in E. Oleracea mart. oil.

The most interesting compounds are identified in the pulp fraction. According to literature, in the pulp of Euterpe Oleracea mart. berry some crucial compounds are present, such as anthocyanins (Cyanidin, Pelargonin), flavonoids (homo-orientin, orientin, catechin epicatechin, p-cumaric), proanthocyanidins, and some other 
interesting products (quercetin, vanillic, ferulic, and gallic acid) [12] [13]. According to Food Technology Institute of São Paulo (ITAL/SP), 100g of fresh fruit has $336 \mathrm{mg}$ of anthocyanins.

These compounds, present in the natural pulp, are expected in different concentration in açaí slurry. Moreover, each fraction has a separate oil content that can cause impedance during the hydrolysis if it is not removed previously. All studies about the characterization of Açaí berry are based on pulp or seeds content, and for this reason, it is necessary to perform a specific and detailed characterization of its byproducts.

Therefore, the objective of this work is to characterize E. Oleracea residues from industry (pulp - not suitable for human consumption -, seeds, and slurry) as biomass and potential phytochemical source, determining the content of lipid, extractives (according their Total polyphenol, anthocyanin, flavonoid and tannins content, and, Antioxidant activity by ORAC value), sugar, ashes, fixed mineral, fibers, protein, and the phytochemical composition of each residual fraction by the same methodology.

\section{Material and methods}

\subsection{Sample}

The raw material was obtained from Obidos-PA-Brazil, consisting of seeds, slurry (fibers and skins retained by the filter), and pulp (not suitable for human consumption). Sample preparation was specific for each fraction of residue: first fraction (seeds) had an average diameter size of $1.2 \mathrm{~cm}$, and it was milled to a size smaller than $5 \mathrm{~mm}$, employing a Retsch SM100 knife-mill, and then dried in an oven at $45^{\circ} \mathrm{C}$ during $48 \mathrm{~h}$. Second and third fractions (slurry and Pulp, respectively) froze at $80^{\circ} \mathrm{C}$ and then lyophilized (Telstar LyoQuest) during $72 \mathrm{~h}$.

\subsection{Characterization as biomass}

\subsubsection{Residual humidity}

The samples present a residual humidity, determined by drying the sample at $45{ }^{\circ} \mathrm{C}$ during 24 hours. This process is also essential as pre-treatment for Soxhlet extraction. Final humidity is given in percentage. 


\subsubsection{Determination of extractives}

The extracts were obtained using a Soxhlet apparatus and a sequence of solvents (hexane, water, and ethanol) to extract each fraction.

Per separately, $4 \mathrm{~g}$ of each residual fraction was placed in an extraction thimble and placed at a Soxhlet apparatus, wherein $100 \mathrm{~mL}$ of hexane was applied as solvent to remove the oil content in each fraction. The material stayed in reflux for 6 hours and temperature was regulated in order to have four cycles per hour. At the end of oil extraction, the filled thimble was placed in an oven at $45^{\circ} \mathrm{C}$ until it achieved constant mass. After extraction, hexane was evaporated in Rotavapor equipment and the oil extracted was solubilized in acetone for better manipulation. When the oil extraction was finalized, the thimble was placed in an oven at $45^{\circ} \mathrm{C}$ until it was completely dry. The extractives recovered were stored for characterization analysis (section 2.3.1).

Once the thimble achieved a constant mass, the mass was recorded, and the thimble containing sample-matrix was placed again in a Soxhlet apparatus to determine water extractive compounds, using $100 \mathrm{~mL}$ of ultrapure water. The material stayed in reflux for 12 hours or until the condensed water was colorless. The temperature was regulated in order to have four cycles per hour. After this, the filled thimble was placed in an oven at $45^{\circ} \mathrm{C}$ until it achieved constant mass. The procedure was repeated with ethanol as solvent. Both extracts were dried using a rotavapor, but in this case, the extract was not solubilized in acetone at the end of the process. The amount of water extractive and ethanol extractive compounds were also determined by the mass lost and confirmed by the dry mass after treatment with rotavapor. For polyphenol characterization (Section 2.3.2), the procedure was repeated, avoiding rotavapor-step, and extractives recovered were stored for analysis.

\subsubsection{Structural carbohydrates and lignin}

Carbohydrates are an essential part of the biomass. They can be part of the structure where they are bound linked, or they can be non-structural. To characterize carbohydrates, a resistant tube was used where $300 \mathrm{mg}$ of sample (after the extraction of extractives described in the previous section) were added together with $3 \mathrm{~mL}$ of sulfuric acid $(72 \% \mathrm{v} / \mathrm{v})$, and incubated for 60 minutes at $30{ }^{\circ} \mathrm{C}$, under stirring. After incubation time, samples were diluted with $84 \mathrm{~mL}$ of pure water. Tubes were transferred into an autoclave at $121^{\circ} \mathrm{C}$ for one hour. 
Finally, content inside tubes was filtered with a vacuum pump in a cellulosic filter. The solids retained on the filter was washed with hot deionized water and then dried at $105^{\circ} \mathrm{C}$, for at least one hour, until constant weigh. After recording the dry mass, samples were transferred to a muffle furnace at $575^{\circ} \mathrm{C}$ for at least 6 hours and until constant mass to determine the percentage of insoluble acid ash.

The liquid in the filtration was recovered for complementary analysis, to determine the contents of soluble lignin and structural carbohydrates. Acid soluble lignin (ASL) was measured by UV-visible spectrophotometer at $240 \mathrm{~nm}$. Samples were diluted in order to have spectra-absorbance in the range of 100-800. To determine structural carbohydrates, $20 \mathrm{~mL}$ of liquid was treated by calcium carbonate until neutralization at $\mathrm{pH} 5-6$ and using of $0.2 \mu \mathrm{m}$ nylon filter to prepare the sample to HPLC analysis. This method was applied in accordance to 'Laboratory Analytical Procedure (LAP) NREL/TP-510-42618’ [14].

\subsubsection{Protein content}

Protein content was indirectly measured by Total Kjeldahl Nitrogen (TKN) method. This method requires digestion of sample in sulfuric acid at $370^{\circ} \mathrm{C}$ during 4 hours, adding copper sulfate as a catalyst. After digestion, DHNa was added and then samples were steam distilled in a solution of boric acid and a violet color marker. Violet color becomes green during the distillation, and the intensity of the green color is proportional to nitrogen content. Finally, the TKN number is given by the amount of ammonia in the receiving solution. To calculate the percentage of protein is necessary to correct the NKT number with a stander nitrogen factor (6.25), as described in standard laboratory Analytical procedure (LAP) NREL/TP-510-42625 [15].

\subsubsection{Total Ash Content}

Ash content is the amount of inorganic material in biomass. It can be divided into two types: structural and extractable. Total ash content measures the amount of inorganic content in biomass. It was determined according to Laboratory Analytical procedure (LAP) NREL/TP-510-42622 [16]: 2 g of original samples (per separated) was dried in an oven at $105^{\circ} \mathrm{C}$ eliminating the volatile content until constant weight. Afterward, they were calcined in a muffle furnace at $575^{\circ} \mathrm{C}$ for at least 1 hour, until constant mass (Determined when the loss-mass is smaller or equals $0.1 \mathrm{mg}$ ). The same procedure was used to determine the structural ash, but in this case, using the solid 
residue of acid hydrolysis (see structural carbohydrates and lignin method). Extractable ash is calculated by the difference between structural ash and total ash.

\subsection{Analytical procedure of extractives}

\subsubsection{Characterization of oil extract}

Determination of the composition of oil obtained by Soxhlet extraction was carried out by the procedure of Fernández-Moya et al., 2000 [17], and quantified according to Carelli and Cert, 1993 [18]. Analyses were carried out in the Seville Oil Institute (Spain). Gas Chromatography (Agilent-7890) was employed to quantify and determine the amount of the main triglycerides in the extract. CG used a capillary column Quadrex Aluminium-Clad 400-65HT (30 m x $0.25 \mathrm{~mm}$ x $0.10 \mu \mathrm{m}$ ), injector at $370^{\circ} \mathrm{C}$ (split of injection at $1: 80$ ), and oven at $335^{\circ} \mathrm{C}$, and detector (FID) at $370^{\circ} \mathrm{C}$. The first step of the sample preparation was the evaporation of the solvent, and then the sample was diluted in heptane with $10 \%(\mathrm{w} / \mathrm{w})$ of Triheptadecanoin $(17: 0-17: 0-17: 0)$ as the internal standard.

\subsubsection{Characterization of extractives in water and ethanol}

The extractives obtained by Soxhlet extraction using water and ethanol as solvents were characterized in terms of total polyphenols content (TPC), total anthocyanins contents (TAC), total flavonoids content (TFC), total tannins content (TTC) and antioxidant activity by oxygen radical absorbance capacity (ORAC). HPLC was used to determine the extract composition.

For TPC analysis a capped test tube was used, adding $40 \mu \mathrm{L}$ of the extract, 3 $\mathrm{mL}$ of ultrapure water and $200 \mu \mathrm{L}$ of folin-ciocalteau reagent. It is also necessary to prepare a control sample using $40 \mu \mathrm{L}$ of extraction solvent, $3 \mathrm{~mL}$ of ultrapure water and $200 \mu \mathrm{L}$ of folin-ciocalteau reagent. Tubes were closed and homogenized at $40^{\circ} \mathrm{C}$ for 5 minutes. After this period $600 \mu \mathrm{L}$ of $\mathrm{Na}_{2} \mathrm{CO}_{3}(20 \% \mathrm{v} / \mathrm{v})$ solution was added, tubes were vigorously stirred, and kept in hot-water-bath at $40^{\circ} \mathrm{C}$ for 30 minutes. At the end, the samples were analyzed by spectrophotometer $(\lambda=765 \mathrm{~nm})$. The TPC concentration is given in Gallic acid equivalent per $100 \mathrm{~g}$ of dry material. [19] 
The TAC analyses were performed with the aid of a spectrophotometer. Samples were diluted (1:4) in a potassium hydroxide buffer $(0.025 \mathrm{M} \mathrm{KCl})$ at $\mathrm{pH} 1.0$ and buffered with acetate trihydrate buffer $\left(\mathrm{CH}_{3} \mathrm{CO}_{2} \mathrm{Na}_{3} 3 \mathrm{H}_{2} \mathrm{O} \quad 0.4 \mathrm{M}\right)$ at $\mathrm{pH} 4.5$. Samples were diluted in both buffers solution, at $\mathrm{pH} 1.0$ and $\mathrm{pH} 4.5$, and each dilution was measured at $520 \mathrm{~nm}$ and $700 \mathrm{~nm}$. The concentration of anthocyanins in each sample is given in $\mathrm{g}$ of cyanidin equivalent per $100 \mathrm{~g}$ of dry material. [20]

To determine TFC $25 \mu \mathrm{L}$ of the sample, $125 \mu \mathrm{L}$ of deionized water, and $7.5 \mu \mathrm{L}$ $\mathrm{NaNO}_{2} 5 \%(\mathrm{v} / \mathrm{v})$ were mixed in a tube. The mixture was incubated at room temperature for 6 minutes. After incubation time $15 \mu \mathrm{L}$ of $\mathrm{AlCl}_{3} \cdot 6 \mathrm{H}_{2} \mathrm{O}(10 \% \mathrm{v} / \mathrm{v})$ and $100 \mu \mathrm{L} \mathrm{NaOH}$ were added to each tube. Each sample was analyzed in a spectrophotometer at $510 \mathrm{~nm}$. [21]

Total Tannins Content (TTC) were determined, mixing $2 \mathrm{~mL}$ of sample in 1 $\mathrm{mL}$ of pure water and $6 \mathrm{~mL}$ of chloridric acid $(12 \mathrm{~N})$. The procedure was carried out in duplicate for each sample, the first tube is placed at hot-water-bath $\left(90^{\circ} \mathrm{C}\right)$ for 30 minutes, and the second tube is saved at room temperature for the same period of time. After incubation time samples are analyzed in a spectrophotometer at $550 \mathrm{~nm}$. [22]

For ORAC assays, in a plate suitable for use in the fluorimeter (12x8 wells) $150 \mu \mathrm{L}$ of Fluorescein Sodium salt solution $(100 \mathrm{nM})$, previously prepared in phosphate buffer ( $\mathrm{pH} 7,4)$ - was added in each used well, and, per triplicate, $25 \mu \mathrm{L}$ of blank, Trolox ${ }^{\circledR}$ (6-Hydroxy-2,5,7,8, tetra-methylchroman-2-carboxylic acid) standard, or Sample, in their designated wells. Trolox ${ }^{\circledR}$ standards were previously prepared in Phosphate Buffer (PBS) pH 7,4, at different concentrations $(13 \mu \mathrm{M}, 25 \mu \mathrm{M}, 50 \mu \mathrm{M}, 100$ $\mu \mathrm{M}$, and, $200 \mu \mathrm{M})$. Once completed, the plate was placed inside the fluorimeter to incubate at $37^{\circ} \mathrm{C}$ for 30 minutes. After the incubation time $25 \mu \mathrm{L}$ of 2,2-azobis(2methylpropionamidine) dihydrochloride (AAPH) (240mM in PBS) was added in each used well. The values, obtained in this experiment, are summarized over time and given as micromole of Trolox ${ }^{\circledR}$ equivalents (TE) per 100gram of dry material ( $\mu$ mol TE / $100 \mathrm{~g}$ of dry material (DM)). [23] [24]

\subsubsection{Sample morphology}


Sample morphology was observed by SEM analysis FLEX SEM 1000 Hitachi, before and after Soxhlet extraction. For this dry sample was placed in support for SEM and covered by gold layer.

\section{Results and Discussion}

\subsection{Biomass characterization}

Characterization of E. Oleracea residue from industry is reported on a base of dry mass material. All results are compiled in table 1.

Table 1- Characterization values ( $\%$ of dry mass)

\begin{tabular}{|c|c|c|c|c|c|c|c|c|c|}
\hline & Humidity & \multicolumn{3}{|c|}{ Extractives } & \multicolumn{3}{|c|}{ Structural Carbohydrate } & Protein & Ash \\
\hline Fraction & & Oil & Aqueous & Ethanolic & Cellulose & Hemicellulose & Lignin & & \\
\hline Dry-Pulp & 1,8 & $43,1 \pm 0,05$ & $23,6 \pm 5,65$ & $1,4 \pm 0,40$ & $5,9 \pm 0,15$ & $4,3 \pm 0,03$ & $9,2 \pm 1,54$ & $7,6 \pm 0,34$ & 1,03 \\
\hline Seed & 8,5 & $3,5 \pm 0,08$ & $13,1 \pm 4,03$ & $0,9 \pm 0,63$ & $8,5 \pm 0,10$ & $48,1 \pm 0,45$ & $16,4 \pm 1,70$ & $9,3 \pm 1,52$ & 0,96 \\
\hline Slurry & 8,2 & $1,2 \pm 0,21$ & $3,4 \pm 0,03$ & $0,3 \pm 0,22$ & $18,6 \pm 0,16$ & $20,7 \pm 0,27$ & $36,2 \pm 1,00$ & $5,8 \pm 0,88$ & 0,67 \\
\hline
\end{tabular}

Extractives represent a total of $68.1 \%, 17.5 \%$, and $4.9 \%$ on pulp, seed, and slurry, respectively. The pulp is the most abundant fraction in terms of extractives, with an oil content of $43.1 \%$, in which $23.6 \%$ are aqueous extractives, $3.4 \%$ are ethanol extractives, and the remaining compounds are hexane extractives. Extracts composition will be detailed in the extracts characterization section. The oil extract is not very representative in seeds and slurry fractions, constituting $3.5 \%$ and $1.2 \%$, respectively. However, it has to be removed in order to avoid any interference because it was observed that oil disturbed the pulp hydrolysis process.

The seeds are a good source of extractives, and the aqueous extract obtained also showed excellent characteristics as a source of antioxidant compounds (see section 3.2.2). Lignocellulosic analysis demonstrated that the açaí seeds are rich in hemicelluloses, which represents around $48 \%$ of the total mass.

The slurry is the poorest fraction in terms of extractives amount. This was expected because slurry is constituted by all the not wanted fragments (such as fibers), resulting from filtering. In the industry, when this fraction is recovered, it has a purple color, given by anthocyanins present on pulp, but it is degraded among time, finally 
shown up a brown tone. In a lignocellulosic analysis, the slurry has shown an $18.6 \%$ of cellulose, $20.7 \%$ of Hemicellulose, and a high amount of lignin of $36.2 \%$.

Seeds and slurry can be proposed as a lignocellulosic biomass feedstock. On industry, cellulose has utility on glucose and ethanol production, and hemicellulose has been applied as an additive in film and barrier coating [25][26]. The key for a successful application of these fractions rests in a correct fractionation and purification method, such as the method proposed by Cantero et al., 2015 [27]. Lignin is a complex structure; its application on industry depends on its fractionation into smaller units, such as cellulose, hemicellulose, and bound phenols [28].

The protein contents, determined by TKN Method, were 9.3\%, 7.6\%, and, $5.8 \%$, for seeds, pulp, and slurry, respectively. These amounts of protein can be considered low, making açaí residue unsuitable as animal-feed. As a reference, pet-food protein value is around $18-36 \%$. The seeds have been tried as an additive, however, the high content of tannins gives it an astringent flavor, and it can interfere in acceptance of it by animals [29]. Ash does not represent a significant percentage in matrix composition in all residual fractions.

\subsection{Extracts characterization}

\subsubsection{Oil}

Açaí pulp-oil is composed by long-chain triglycerides, and the main components are Palmitodiolein (16:0-18:1-18:1) (26.97\%) and Triolein (18:1-18:118:1) (17.18\%), as described in Table 2 where the triglycerides profile present in pulp oil are summarized based on total oil fraction. The oil is composed basically of Oleic (18:1) (58.5\%), Linoleic (18:2) (22.3\%), Palmitic (16:0) (11.4\%), Stearic (18:0) (4.1\%), and Palmitoleic (16:1) acids (3.7\%).

The oil obtained from açaí can be considered a product of interest for nutraceutical applications because of its high concentration of Oleic acids (omega-9), the presence of essential fatty acids such as Linoleic acid that are not naturally produced by human metabolism, and the strong presence of other unsaturated-chain acids. These types of unsaturated fatty acids are beneficial to human health because they help to prevent diseases such as diabetes, and high blood pressure by reducing triglyceride 
levels and blood cholesterol (LDL). The ratio between unsaturated and saturated fatty acids can be used as a quality parameter. In this case, the pulp oil has a rate of 2.3.

Açaí oil characteristics are comparable to olive oil in terms of fatty acids proportion presented in Alimentarius codex of 2003 (Oleic 58.5-83.2\%, Linoleic 2.821.1\%, and Palmitic 7.8-18.8\%). It was also observed that in both oils Triolein (OOO) and Palmitodiolein (POO) are the main triacylglycerols in the oil composition. The proportion of POO was quite higher in açaí oil than in olive oil (12-20\%), and OOO content is much higher in olive oil (40-59\%) [30].

Based on these results, Açaí oil can be proposed as an omega source for industry depending on the lipolysis process. Bioprocess has been successfully applied to this goal by the enzymatic lipase of triacylglycerol, where it was possible to release Oleic and Linoleic fatty acids [31].

Table 2: Triglycerides on Açaí pulp oil extract.

\begin{tabular}{ccc}
\hline & Pulp Oil \\
Triglyceride & Average (\%) & sd \\
\hline POO & 26,97 & 0,2 \\
OOO & 17,18 & 0,36 \\
POL+PoOL & 12,57 & 0,14 \\
POP & 11,76 & 0,16 \\
PLP+PPoO & 6,68 & 0,28 \\
OOL & 5,63 & 0,14 \\
SOL & 3,9 & 0,12 \\
PLS & 3,48 & 0,37 \\
PLL & 3,14 & 0,16 \\
SOO & 2,26 & 0,14 \\
PLPo+PoPoO & 1,37 & 0,12 \\
POS & 1,73 & 0,03 \\
OLL & 1,63 & 0,42 \\
SLL & 1,19 & 0,03 \\
SLS & 0,26 & 0,05 \\
SOS & 0,25 & 0,03 \\
\hline
\end{tabular}

P: palmtic, 16:0; Po: palmitoleic, 16:1; S: estearic, 18:0; O: oleic, 18:1; L: linoleic, 18:2.

\subsubsection{Aqueous and ethanolic extracts}

The aqueous extract obtained from Soxhlet is composed of sugars, nitrogen compounds, minerals, among other water-soluble compounds such as anthocyanin and some polyphenols. In the aqueous extract, the pulp has shown $23.1 \%$ of extractives on dry mass, seeds $13.1 \%$, and, slurry $3.4 \%$. Ethanolic extractives were not present in 
significant amounts, which may be due to the previous extraction. Both extracts, ethanolic and aqueous, were analyzed according to their anthocyanin (TAC), polyphenol (TPC), flavonoid (TFC) and tannins (TTC) total content. Extracts were also classified according to their antioxidant activity by oxygen radical antioxidant capacity (ORAC).

The ORAC for water-soluble antioxidant compounds found for the pulp and slurry were 89760 and $7870 \mu \mathrm{mol} \mathrm{TE} / 100 \mathrm{~g}_{\mathrm{DM}}$, respectively. The ORAC values found are close to those provided by the ORAC Database of U.S. Department of Agriculture for pulp and skin: $99700 \mu \mathrm{mol} \mathrm{TE} / 100 \mathrm{~g}_{\mathrm{DM}}$. It is necessary to sum these ORAC-values obtained in the hydrophilic phase for slurry and pulp fractions for a better comparison, $97630 \mu \mathrm{mol} \mathrm{TE} / 100 \mathrm{gDM}_{\mathrm{DM}}$. This antioxidant capacity in water-soluble phase is similar to that observed in the same portion of Sage spices $\left(98714 \mu \mathrm{mol} \mathrm{TE} / 100 \mathrm{~g}_{\mathrm{DM}}\right)$, thirty times bigger than Goji Berry $\left(3170 \mu \mathrm{mol} \mathrm{TE} / 1100 \mathrm{~g}_{\mathrm{DM}}\right)$, and sixty times than red grape (1640 $\left.\mu \mathrm{mol} \mathrm{TE} / 100 \mathrm{~g}_{\mathrm{DM}}\right)$. Seeds extracts had $65263 \mu \mathrm{mol} \mathrm{TE} / 100 \mathrm{~g}_{\mathrm{DM}}$ of antioxidant activity similar to the pulp antioxidant capacity [32].

Ethanolic and oil antioxidant content values together should be equivalent to ORAC of for fat-soluble antioxidant compounds (pulp: $1158 \mu \mathrm{mol} \mathrm{TE} / 100 \mathrm{gDM}$; slurry: $467 \mu \mathrm{mol}$ TE/100gDM; Seeds: $6310 \mu \mathrm{mol}$ TE/100gDM), but these phases suffered different treatments and thermal-treatments that can disturb final data. Açaí pulp and seeds have shown a higher amount of aqueous soluble polyphenols, 2.86 and 1.77 GA eq/100g $\mathrm{g}_{\mathrm{DM}}$, respectively, than ethanol-soluble polyphenols, 0.33 and $0.28 \mathrm{GA}$ eq $100 \mathrm{~g}_{\mathrm{DM}}$, respectively. On the other hand, a similar amount of polyphenols content has been found in both phases of slurry fraction, $0.16 \mathrm{GA}$ eq $/ 100 \mathrm{~g}_{\mathrm{DM}}$ in water, and 0.10 GA eq/100gDM in ethanol extract.

There is a similar concentration of water-soluble material in pulp (0.253 $\left.\mathrm{g} / 100 \mathrm{~g}_{\mathrm{DM}}\right)$ and seed $\left(0.242 \mathrm{~g} / 100 \mathrm{gDM}_{\mathrm{DM}}\right)$ fractions, as well are observed for ethanolic extract $0.104 \mathrm{~g} / 100 \mathrm{~g}_{\mathrm{DM}}$ on pulp and $0.116 \mathrm{~g} / 100 \mathrm{~g}_{\mathrm{DM}}$ on seeds. On slurry fractions, the value in the ethanolic extract $\left(0.090 \mathrm{~g} / 100 \mathrm{~g}_{\mathrm{DM}}\right)$ was slightly higher than in the aqueous extract $\left(0.082 \mathrm{~g} / 100 \mathrm{~g}_{\mathrm{DM}}\right)$, which is probably associated with the pre-treatment applied in the industry.

Tannins are a significant fraction of seeds polyphenols, also responsible for the astringent flavor of seeds. They are present in aqueous extract, $32.94 \mathrm{~g} / 100 \mathrm{~g}$, and, in the ethanolic extract, $13.37 \mathrm{~g} / 100 \mathrm{~g}$. On pulp, tannins are concentrated in the water phase (73.40g/100gDM) and almost not present on ethanolic extract (3.41 g/100gDM). The 
presence of tannins in the slurry is scarce both in the aqueous phase $\left(2.61 \mathrm{~g} / 100 \mathrm{~g}_{\mathrm{DM}}\right)$ and in the ethanolic phase $(5.82 \mathrm{~g} / 100 \mathrm{gDM})$. All these compounds contribute to the antioxidant capacity of the extract.

Anthocyanin was identified in pulp fraction at a concentration of $293.29 \mathrm{mg} / 100 \mathrm{~g}$ dry material, which is close to the value found by Iaderoza (1992) 336 $\mathrm{mg} / 100 \mathrm{~g}_{\mathrm{DM}}$, and, Schauss (2006) $319.19 \mathrm{mg} / 100 \mathrm{~g}_{\mathrm{DM}}$ of dry material [33][34]. The presence of anthocyanin was not observed on the slurry fraction, as expected as this compound can be easily degraded resulting from a poor storage condition on industry and transportation.

Although ethanolic extracts have been not considered representative as a percentage on the dry material, polyphenols, flavonoids, and tannins were identified on them. As expected, anthocyanin just was detected on the aqueous extract.

\subsection{Morphology}

The process to obtain the pulp in the industry consists of mixing the material with hot water under constant stirring proportioned by the continuous rotation of shaftmixer. Hot water is necessary to avoid microbial growth in the product. In general, the pulping process is similar to a maceration process, and as a result the slurry matrix becomes more 'damaged'. It explains why original slurry and slurry after Soxhlet extraction do not show a significant difference as observed by microscopy pictures (table 3).

On the other hand, seeds are removed by a secondary stream at the beginning of the pulping process. As a result, the extractives content in this fraction of residue is better preserved. Seeds size also has an essential role in the conservation of seed's extractives. However, as particle size influences the content of extract, and in order to facilitate extraction by Soxhlet, particle size was reduced mechanically by milling. Through the SEM image (table 3) it is possible to observe the side-cut of seed and its structures, but after Soxhlet extraction, this structure disappears. In addition, fibers are responsible for protecting the internal content of seeds during the germination, so most fibers are in the seed fraction, but the movement of pulping shafts break same of them that are posteriorly removed from the pulp by filtering. Therefore, it is possible to find fibers in both fractions. 
Table 3- SEM Characterization of Slurry and Seed

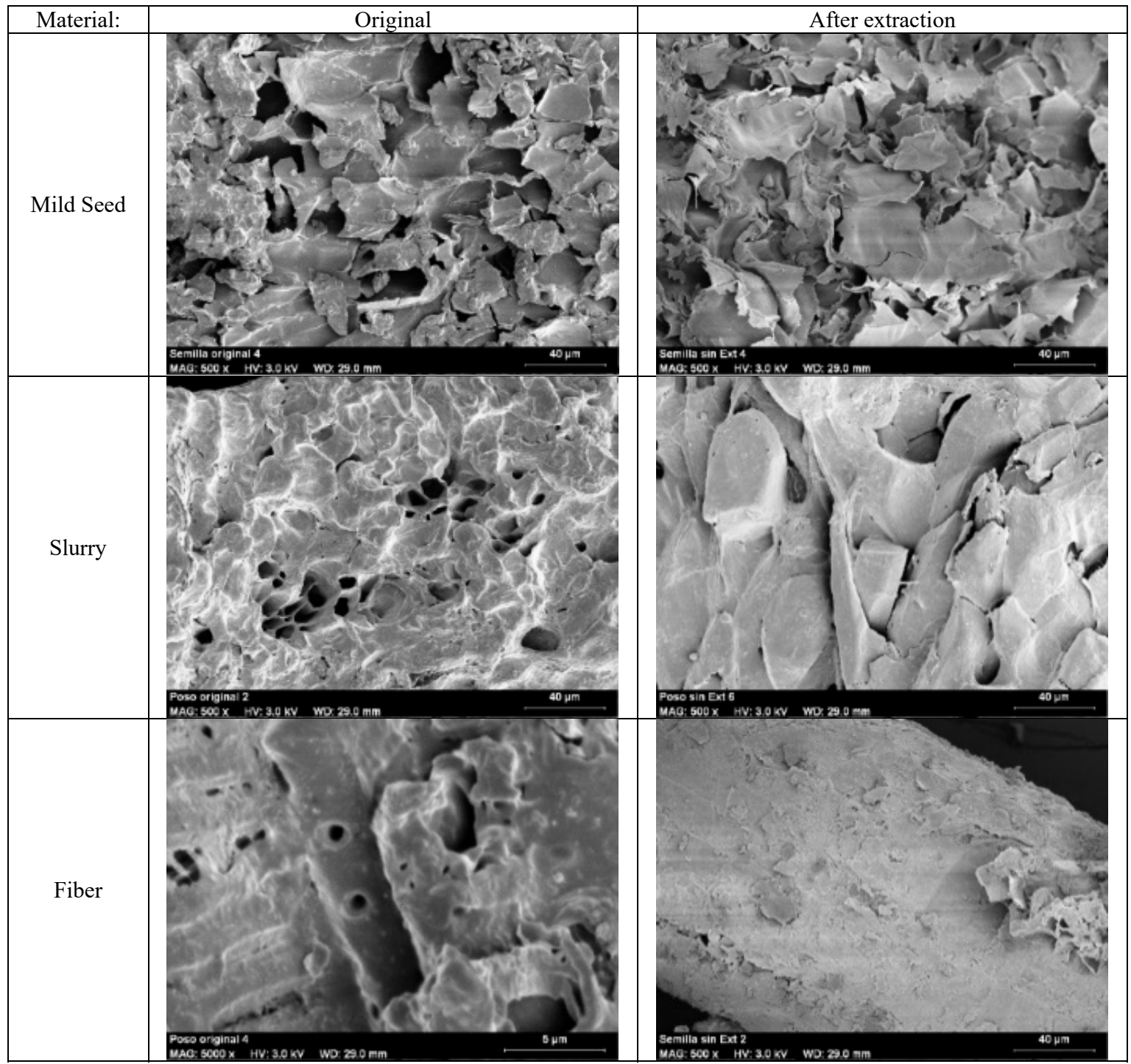

\section{Conclusion}

The primary by-products of the industrial processing of acai fruit have been characterized. In terms of extractive compounds, the pulp fraction showed high potential as oil source, with contents up to $43 \%$ on dry mass. On pulp oil, fatty acids were present such as oleic acid (58.5\%), linoleic acid (22.3\%), palmitic acid (11.4\%), and stearic acid (4.1\%). Pulp and seeds presented considerable values of water-soluble extractives, $23 \%$, and $13 \%$, respectively. Moreover, these extracts exhibited substantial amounts of total polyphenols and flavonoids with a high quantity of ORAC activity. 
Although the slurry presented lower values of total extractives, polyphenols, and flavonoids in comparison to the other fractions, the water-soluble slurry extract presented antioxidant activity. Values were lower than expected, and it was attributed to the previous process applied in the industry.

Cellulose, hemicellulose, and lignin are the main components of the slurry fraction, with contents of $18 \%, 20 \%$, and, 36\%, respectively. On seeds, the main component found was hemicellulose, containing up to $48 \%$.

This residual fraction could be proposed as a feedstock of these components on lignocellulosic biorefinery by hydrolysis of oligomers in small sugar-fractions which can be later applied in the obtention of fuels, chemicals, polymers, and other types material [35]. Further studies in this area are necessary.

\section{References}

[1] P.A.L. Barbosa, Pequeno Vocabulario Tupi-Protuguês, 1st ed., Livraria São José, Rio de Janeiro, 1951.

[2] H. Lorenzi, L. Noblick, F. Kahn, E. Ferreira, Flora Brasileira: Arecaceae (Palmeiras), Inst. Plantarum, Nov. Odessa. (2010) 211-212.

[3] M. Oliveira, J.E.U. De Carvalho, W.M.O. Do Nascimentio, C.H. Muller, Cultivo do açaizeiro para produção de frutos., Embrapa Amaz. Orient. Circ. Técnica. (2002).

[4] R.F.A. Altman, O caroço de açaí, Instituto agrônomico Norte, Belém, Pará, 1956. https://ainfo.cnptia.embrapa.br/digital/bitstream/item/69985/1/IAN-BT31P109.pdf.

[5] H. Rogez, Açaí: Preparo, Composição e Melhoramento da Conservação, 2000.

[6] R.B. Rodrigues, R. Lichtenthäler, B.F. Zimmermann, M. Papagiannopoulos, H. Fabricius, F. Marx, J.G.S. Maia, O. Almeida, Total oxidant scavenging capacity of Euterpe oleracea Mart. (açaí) seeds and identification of their polyphenolic compounds, J. Agric. Food Chem. 54 (2006) 4162-4167.

[7] E. Fahy, D. Cotter, M. Sud, S. Subramaniam, Lipid classification, structures and tools., Biochim. Biophys. Acta. 1811 (2011) 637-47.

[8] C.C.R. Batista, A.P.M. Santos, A.P.S. Silva, R.M. Cordeiro, N.T. Machado, 
A.M.C. Rodrigues, R.N. Carvalho Jr, Obtenção De Extratos Da Polpa De Açaí ( Euterpe Oleracea ) Liofilizada Por Extração Supercrítica: Isotermas De Rendimento Global E Composição Em, (2010) 1-7.

[9] C. Lubrano, J.R. Robin, A. Khaiat, Fatty acid, sterol and tocopherol composition of oil from the fruit mesocarp of six palm species in French Guiana, Oléagineux. 49 (1994) 59-65.

[10] I.S.B. Mantovani, S.B.O. Fernandes, F.S. Menezes, Constituintes apolares do fruto do açaí (Euterpe oleracea M. - Arecaceae), Rev. Bras. Farmacogn. 13 (2003) 41-42.

[11] M.J. Plotkin, M.J. Balick, Medicinal uses of South American palms, J. Ethnopharmacol. 10 (1984) 157-179.

[12] J. Kang, Z. Li, T. Wu, G.S. Jensen, A.G. Schauss, X. Wu, Anti-oxidant capacities of flavonoid compounds isolated from acai pulp (Euterpe oleracea Mart.), Food Chem. 122 (2010) 610-617.

[13] M. Heinrich, T. Dhanji, I. Casselman, Aai (Euterpe oleracea Mart.) - A phytochemical and pharmacological assessment of the species' health claims, Phytochem. Lett. 4 (2011) 10-21.

[14] A. Sluiter, B. Hames, R. Ruiz, C. Scarlata, J. Sluiter, D. Templeton, D. Crocker, Determination of Structural Carbohydrates and lignin in biomass, 2008.

[15] B. Hames, C. Scarlata, A. Sluiter, Determination of Protein Content in biomass, 2008.

[16] A. Sluiter, B. Hames, R. Ruiz, C. Scarlata, J. Sluiter, D. Templeton, Determination of Ash in Biomass, 2005.

[17] V. Fernández-Moya, E. Martínez-Force, R. Garcés, Identification of Triacylglycerol Species from High-Saturated Sunflower (Helianthus annuus) Mutants, J. Agric. Food Chem. 48 (2000) 764-769.

[18] A.A. Carelli, A. Cert, Comparative study of the determination of triacylglycerol in vegetable oils using chromatographic techniques, J. Chromatogr. A. 630 (1993) 213-222.

[19] V.L. Singleton, R. Orthofer, R.M. Lamuela-Raventós, Analysis of total phenols and other oxidation substrates and antioxidants by means of folin-ciocalteu reagent, Methods Enzymol. 299 (1999) 152-178.

[20] AOAC Official Method, Total Monomeric Anthocyanin Pigment Content of Fruit Juices, Beverages, Natural Colorants, and Wines, in: AOAC Int. 37.1.68, 
2005.

[21] A. Michalska, A. Ceglińska, H. Zieliński, Bioactive compounds in rye flours with different extraction rates, Eur. Food Res. Technol. 225 (2007) 545-551.

[22] P. Ribéreau-Gayon, E. Stonestreet, Le dosage des tannins du vin rouge et la détermination de leur structure, Chim. Anal. 48 (1966) 188-196.

[23] B. Ou, M. Hampsch-Woodill, R.L. Prior, Development and validation of an improved oxygen radical absorbance capacity assay using fluorescein as the fluorescent probe, J. Agric. Food Chem. 49 (2001) 4619-4626.

[24] F. Ganske, ORAC Assay on the FLUOstar OPTIMA to Determine Antioxidant Capacity, Offenburg, Germany, 2006.

[25] Y. Zhu Ryberg, U. Edlund, A.C. Albertsson, Innovative approaches for converting a wood hydrolysate to high-quality barrier coatings, ACS Appl. Mater. Interfaces. 5 (2013) 7748-7757.

[26] K.S. Mikkonen, S. Heikkinen, A. Soovre, M. Peura, R. Serimaa, R.A. Talja, H. Helén, L. Hyvönen, M. Tenkanen, Films from oat spelt arabinoxylan plasticized with glycerol and sorbitol, J. Appl. Polym. Sci. 114 (2009) 457-466.

[27] D.A. Cantero, C. Martínez, M.D. Bermejo, M.J. Cocero, Simultaneous and selective recovery of cellulose and hemicellulose fractions from wheat bran by supercritical water hydrolysis, Green Chem. 17 (2015) 610618.

[28] M.J. Cocero, Á. Cabeza, N. Abad, T. Adamovic, L. Vaquerizo, C.M. Martínez, M.V. Pazo-Cepeda, Understanding biomass fractionation in subcritical \& supercritical water, J. Supercrit. Fluids. 133 (2018) 550-565.

[29] O. Seye, R.C.R. Souza, A.A. Bacellar, M.R. Morais, Caracterização do Caroço de Açaí Como Insumo Parageração de Eletricidade Via Gaseificação, in: 7 Congresso Internacional sobre Geração distribuída e Energia no meio Rural, Fortaleza, Brasil, 2008.

[30] D. Boskou, G. Blekas, M. Tsimidou, Olive Oil, Chemistry and Technology, in: Olive Oil ; Chem. Technol. 2 Nd Ed., 2006: pp. 41-43.

[31] M.M. Perez, E.C. Spiropulos Goncalves, J.C. Santos Salgado, M. de S. Rocha, P.Z. de Almeida, A.C. Vici, J. da C. Infante, J. Manuel Guisan, J. Rocha-Martin, B. Costa Pessela, M. de L. Teixeira de Moraes Polizeli, Production of Omegas-6 and 9 from the Hydrolysis of Acai and Buriti Oils by Lipase Immobilized on a Hydrophobic Support, Molecules. 23 (2018) 3015.

[32] D.B. Haytowitz, S. Bhagwat, USDA, Database for the Oxygen Radical 
Absorbance Capacity (ORAC) of Selected Foods, Release 2, 2010. http://www.orac-info-portal.de/download/ORAC_R2.pdf.

[33] A.G. Schauss, X. Wu, R.L. Prior, B. Ou, D. Patel, D. Huang, J.P. Kababick, Phytochemical and nutrient composition of the freeze-dried amazonian palm berry, Euterpe oleraceae Mart. (Acai), J. Agric. Food Chem. 54 (2006) 85988603.

[34] M. Iaderoza, V.L.S. Baldini, I.D.S. Draetta, M.L.A. Bovi, Anthocyanins from fruits of acai (Euterpe oleraceae Mart.) and jucara (Euterpe edulis Mart.), 1992. 32 (1992) 41-46.

[35] G. Gallina, Hemicellulose production using hot pressurized water: from lab to pilot scale, Thisis, University of Valladolid, 2017. 


\section{Chapter 2}

Extraction of Polyphenols from Euterpe Oleracea Mart. (açaí) Wastes 
Chapter 2 


\begin{abstract}
Açaí (Euterpe Oleracea Mart.) is a black-purple berry, typically found in Amazon Rainforest. E. Oleracea product is a natural phytochemical source, which shows a high content of polyphenols and flavonoids. It also presents remarkable properties as an antioxidant. This work studied the extraction of bioactive compounds from the main residues produced by the food industry during the processing of Açai: pulp, slurry, and seeds of E. Oleracea fruit. Maceration, Microwave Assisted Extraction (MAE) and pressurized MAE (PMAE) were applied as extraction technique and as pre-treatment for extraction, respectively. Ethanol, water and ethanol/water (1:1) were used as solvents for the extraction, determining the efficiency and selectivity of the extraction for each solvent at temperatures of $60^{\circ} \mathrm{C}$ and $80^{\circ} \mathrm{C}$. Extracts were characterized in terms of extraction yield, total polyphenols content (TPC), total Anthocyanins contents (TAC), and antioxidant activity by oxygen radical absorbance capacity (ORAC). For both fractions of residue, the highest TPC values were found using ethanol/water (1:1) as the solvent and performing extraction at $60^{\circ} \mathrm{C}$. Applying MAE (300W, 30seconds) as a pre-treatment of slurry material promoted an increase of TPC values, from $269 \mathrm{mgGAE} / \mathrm{L}$ to 735 mgGAE/L, after 30 minutes of extraction. Extraction of seeds was not affected by MAE (300W, 30seconds) pre-treatment. Nevertheless, seeds show higher potential as polyphenols source than slurry, in terms of TPC values (29057 mg GAE/L in the case of seeds compared to $735 \mathrm{mgGAE} / \mathrm{L}$ in slurry, at the same extraction conditions). In contrast, slurry shows potential as anthocyanin (Peoniding and Cyanidin) source, compounds that are not present in seeds extract.
\end{abstract}

Keywords. Euterpe Oleracea Mart.; açaí by-products; açaí seeds; açaí-Oil. 


\section{Introduction}

Açaí ( yasa'I - fruit that cries- Brazilian Portugues conformity[1]) is a blackpurple berry obtained from Euterpe Oleracea mart. palm, typically found in Amazon Rainforest. The fruit has a massive acceptance among the Brazilian population, and each time it becomes better known due to its properties as an antioxidant. The product consumption forecast for 2020 is $6 \times 10^{5}$ tons in the local market (the northeast region of Brazil), $2 \times 10^{5}$ tons in the Brazilian national market, and $2.5 \times 10^{4}$ tons in the outside world. It implies in the generation of a vast quantity of waste, composed of seeds and slurry-filtrate. Moreover, when the batch of pulp is considered inappropriate for consumption, it is destined to residue in its totality. All fractions of waste can be observed in Figure 1. In this way, it is necessary to promote the use of the residue in the industry, especially in the chemical sector, reducing the environmental impact through fostering the valorization of açaí by-products. Nowadays, the açaí seed is used in the manufacture of handicrafts; however, it can be used as an alternative source for phytochemicals (especially tannins and flavonoids) acquisition, using an adequate extraction method. The pulp, not able to consume, has potential as a source of high-value active-substances, such as anthocyanins (cyanidin 3-glucoside; 2, pelargonidin 3-glucoside) [2][3], flavonoids (orientin, homoorientin, vitexin, luteolin, velutin) [4][5], proanthocyanidins, among others [6].

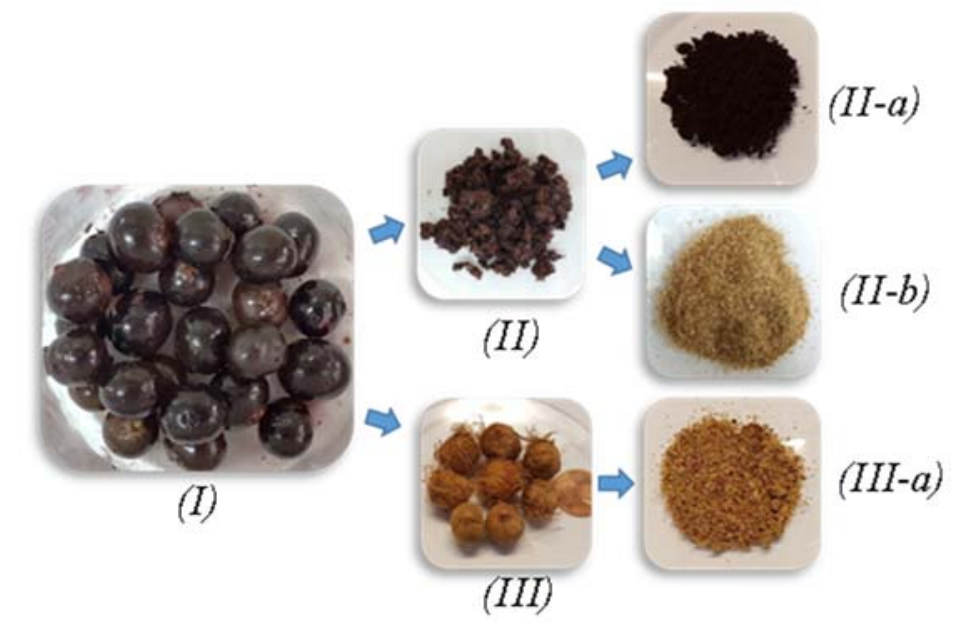

Figure 1 - (I) E. Oleracea (Açaî) in nature; (II)Pulp in nature, (II-a) Dry-pulp, and (II-b)Dry Slurry; (III) Seeds and (III-a) mild-seeds. 
Polyphenols are secondary metabolites of plants with remarkable properties like antioxidant activities, and an important class of phytochemical substance. Tannins, flavonoids, and, anthocyanins are subgroups in the polyphenols classification, and their importance rests on their unique properties such as antioxidant, anti-inflammatory, and antimicrobial functions, among others [7], being useful substances to apply in pharmaceutical, cosmetic, and food products.

The maceration process is a traditional methodology to extract fitochemichals from natural materials. The technique is wieldy used in wine production. The raw material for extraction is soaking in water and/or organic solvent. The process usually takes place at room temperature and requires many hours to be concluded. Depending on the raw material, sometimes it is necessary to increase the temperature of the process to achieve a better extraction yield.

Microwave-Assisted Extraction (MAE) and pressurized MAE (PMAE) are methodologies which are able to be used as pre-treatment in the maceration process, working into reducing the time to achieve the maximum extraction yield because of the microwave energy acts into the slow diffusion steps of extraction [8]. The microwave provides energy that heats the intracellular water, increasing the pressure inside of the vegetal-cell, which promotes the cell-wall rupture. Finally, the internal-cell content is released, resulting in a drastic acceleration of the diffusion step. Evidence of these advantages have been observed in the treatment of by-products of wine: skin and seeds of grapes; by MAE the time needed to extract the maximum amount of polyphenols decreased to only 3 minutes, against 60 min without MAE [9]. The increased temperature provided by microwave energy change the dielectric constant, and it also helps to reduce the time for extraction [10], contributing to reduce the degradation of the compounds during the extraction.

In this way, this paper aims to perform the extraction of the different by-products obtained during the açaí processing, which can be classified into three fractions: seeds, slurry, and pulp. To carry out this study, maceration process has been selected as the extraction method, and MAE and PMAE were selected as intensification pre-treatment extraction to discourse about their effects on the material and their application to valorizing E. Oleracea by-products. 


\section{Material and methods}

\subsection{Sample preparation}

The sample preparation is specific for each waste fraction. The sample was collected and processed in Obidos-Pará-Brazil. After the following sample-preparation, all waste fractions were storage at $-80^{\circ} \mathrm{C}$.

\subsubsection{Seeds}

The seeds are ground by the use of a knife-mill (Retsch SM100). The final material has $5 \mathrm{~mm}$ average granular-size. Finally, the content is dried at $45^{\circ} \mathrm{C}$ for $48 \mathrm{~h}$ in an oven.

\subsubsection{Pulp and slurry}

The pulp and the slurry were frozen and then lyophilized (Telstar LyoQuest) for 72hours.

\subsection{Extraction}

\subsubsection{Maceration}

The maceration process started when the raw material is placed in the glassextractor, mixed and homogenized with the solvent. Temperature and stirring are kept constant. Pure ethanol, pure water, and ethanol/water (1:1), acidified at $\mathrm{pH} 3.0$, were used as solvents. The temperature was kept at $40^{\circ} \mathrm{C}$ and $60^{\circ} \mathrm{C}$.

\subsubsection{Microwave-assisted Extraction (MAE)}

Before the extraction the raw material and solvent were placed in an open flask and homogenized under constant and moderate stirring for 2 min. The flask is then introduced into the pre-heated microwave (CEM) where the pre-treatment takes place. The CEM was set to a constant power (300W) and regular time (30 seconds) while the temperature was varied till ebullition. After pre-treatment the sample was suddenly cooled introducing the flask into a cold bath. 
The PMAE process is similar to MAE procedure, with the difference in the flasktype utilized, as in the PMAE the flask is closed and has the pressure controller. Again, the CEM was set to constant power (300W) and regular time (30 seconds), varying the temperature till ebullition and sample was suddenly cooled introducing the flask into a cold bath.

\subsection{Quantification and identification analysis}

\subsubsection{Total polyphenols content (TPC)}

In a tube, $40 \mu \mathrm{L}$ of the extract, $3 \mathrm{~mL}$ of ultrapure water and $200 \mu \mathrm{L}$ of folinciocalteau reagent were added. Blank control is required, and it was prepared using $40 \mu \mathrm{L}$ of extraction solvent, $3 \mathrm{~mL}$ of ultrapure water and $200 \mu \mathrm{L}$ of folin-ciocalteau reagent. Tubes were closed, homogenized and thermo-stabilized at $40^{\circ} \mathrm{C}$ for 5 minutes. Then, $600 \mu \mathrm{L}$ of $\mathrm{Na} 2 \mathrm{CO} 3(20 \% \mathrm{v} / \mathrm{v})$ solution was added, tubes were vigorously stirred, and incubated in hot-water-bath at $40^{\circ} \mathrm{C}$ for 30 minutes. Finally, samples were analyzed by spectrophotometry $(\lambda=765 \mathrm{~nm})$. The TPC concentration is given in Gallic acid equivalent per $100 \mathrm{~g}$ of dry material $[11,12]$.

\subsubsection{Total Anthocyanin contents (TAC)}

Samples were diluted (1:4) in a potassium hydroxide buffer $(0.025 \mathrm{M} \mathrm{KCl})$ at $\mathrm{pH}$ 1.0 and in acetate trihydrate buffer $\left(\mathrm{CH}_{3} \mathrm{CO}_{2} \mathrm{Na} .3 \mathrm{H}_{2} \mathrm{O} 0.4 \mathrm{M}\right)$ at $\mathrm{pH} 4.5$. Both dilutions were measured in a spectrophotometer at $520 \mathrm{~nm}$ and $700 \mathrm{~nm}$ wavelength. The concentration of anthocyanin, in each sample, is given in in cyanidin equivalent per 100 $\mathrm{g}$ of dry material $[12,13]$.

\subsubsection{Oxygen radical absorbance capacity (ORAC)}

In a plate designed for fluorimetry (12x8 wells) $150 \mu \mathrm{L}$ of Fluorescein Sodium salt solution (100 nM, previously prepared in phosphate buffer $(\mathrm{pH} 7,4)(\mathrm{PBS}))$ was added in each used well, and, per triplicate, $25 \mu \mathrm{L}$ of blank, Trolox ${ }^{\circledR}(6-H y d r o x y-2,5,7,8$,tetramethylchroman-2-carboxylic acid) standard, or Sample, were added in their designated wells. Trolox ${ }^{\circledR}$ standards were previously prepared in PBS, at different concentration $(13 \mu \mathrm{M}, 25 \mu \mathrm{M}, 50 \mu \mathrm{M}, 100 \mu \mathrm{M}$, and, $200 \mu \mathrm{M})$. Once completed, the plate was placed inside a fluorimeter to incubate at $37^{\circ} \mathrm{C}$ for 30 minutes. After the incubation time, $25 \mu \mathrm{L}$ of 2,2-azobis(2-methylpropionamidine) dihydrochloride (AAPH) (240mM in PBS) was added in each used well. The values, obtained in this experiment, are summarized over 
time, sand is given as micromol of Trolox ${ }^{\circledR}$ equivalents (TE) per $100 \mathrm{~g}$ of dry material $(\mu \mathrm{mol} \mathrm{TE} / \mathrm{g}$ of dry material $[12,14,15]$.

\subsubsection{Experimental design}

The experimental design was divided into two main parts. In the first experimental design, the set goal was to determine the best conditions to extract polyphenols from slurry and seeds by conventional maceration to maximize the amount of Total Polyphenol Content (TPC) in extracted material. Studding by this way, the interaction between solvent (percentage of ethanol), temperature $\left(40^{\circ} \mathrm{C}\right.$, and $\left.60^{\circ} \mathrm{C}\right)$, and time of extraction $(0-360$ minutes $)$. Once achieved this goal, the second experimental design created starts from the best conditions found to extraction by maceration to looking for the optimal condition, aiming to increase the TPC value of extracts now considering the application of pre-treatment MAE and PMAE as intensification process.

\section{Results and Discussions}

Figure 2 shows the results of the water extraction experiments, with and without microwaves. Two temperatures have been studied, $40^{\circ} \mathrm{C}$ and $60^{\circ} \mathrm{C}$. Yields of around $0.12 \%$ and $0,06 \%$ are observed, with extraction times of 5 minutes, it is seen that the yield increased when the microwave is used, and it increased even more when high temperature is applies. However, the extraction yield was not high concerning the other solvents tried, due to the presence of oil in the sample, which create an impedance to extraction, anyway slurry (composed by skins and fibbers from the filtrate step) is not a fraction rich in extractives. Water is not a suitable solvent for açaí slurry extraction: this residue has an oil content which hampers the penetration of solvent in the matrix. The time to achieve the maximum extraction yield (MEY) was reduced by MAE application. Temperature is a relevant parameter to be studied in extraction condition even for no pre-treatments maceration process when it is increased in $20^{\circ} \mathrm{C}$ the time to achieve MEY decrease in 30 minutes. It was expected a higher amount of total polyphenols in the slurry. 


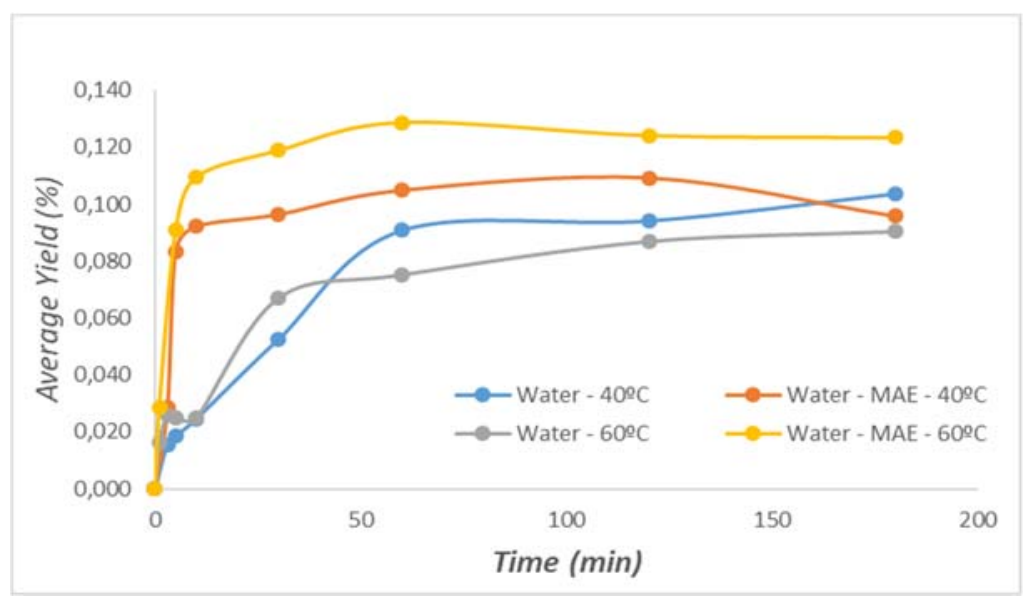

Figure 2- extraction curve of the slurry fraction with and without microwave pre-treatment, at $40^{\circ}$ and $60^{\circ} \mathrm{C}$, using water as the solvent.

The use of a non-specific solvent, as ethanol/water, shows more efficiency when compared with Soxhlet global extractive amount, $4.428 \%$. Ethanol/water at $60^{\circ} \mathrm{C}$ was the best extraction condition for slurry matrix, $0.614 \%$ against $4.428 \%$ from Soxhlet characterization. The maximal yield extract was achieved using MAE as pre-treatment.

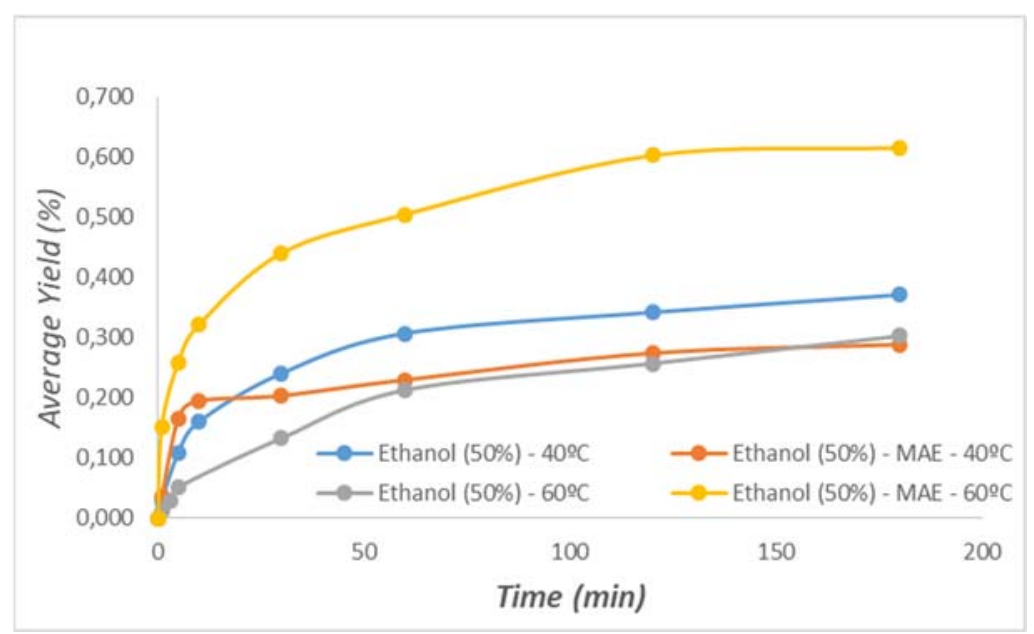

Figure 3- extraction curve of the slurry fraction with and without microwave pre-treatment, at $40^{\circ}$ and $60^{\circ} \mathrm{C}$, using Ethanol $(50 \%)$ as solvent.

Pure ethanol has potential as selective extraction solvent, $0.107(\%)$ against $0.188(\%)$ found for Soxhlet ethanol extractive; It is not possible to identify the best condition for extraction using ethanol, because was not possible to observe a patron. 


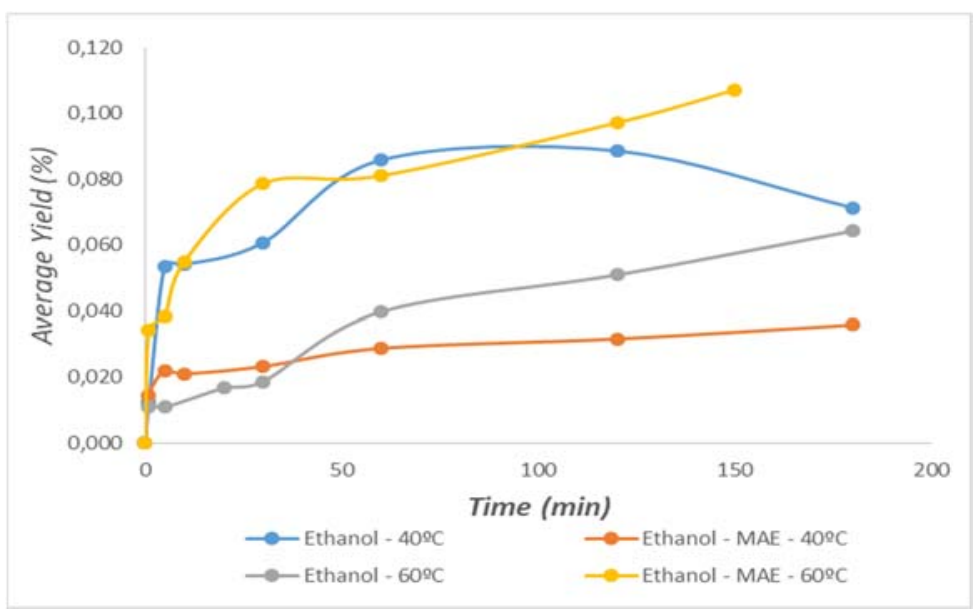

Figure 4- extraction curve of the slurry fraction with and without microwave pre-treatment, at $40^{\circ}$ and $60^{\circ} \mathrm{C}$, using Ethanol as solvent.

ORAC measures the antioxidant capacity of extracts. Temperature plays an essential role during the extraction process, and it can act in the amount of phytochemicals and its early degradation. Microwave helps the extraction process promoting a fast increase of temperature; Matrix has a short time exposition of this excessive temperature, which decreases the degradation. The extract obtained using ethanol/water has better potential as antioxidant because of low solvent selectivity. Results show that maceration temperature is also important to achieve an excellent antioxidant extract. Microwave has a positive effect when ethanol (50\%) was applied and to pure ethanol, however this behavior was not observed to extraction performed using pure water as solvent, that could be attributed to the oil content present in the material.

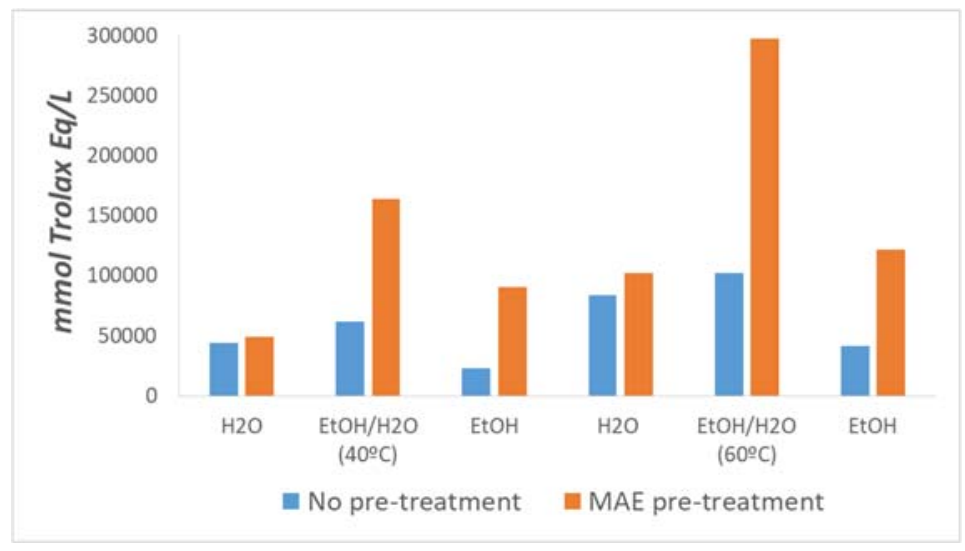

Figure 5 - Antioxidant activity (ORAC) of extract contenting 


\section{Conclusions}

Temperature is an essential parameter in extraction using Açaí (E. Oleracea) slurry as matrix; Oil content could be an impediment when water was used as solvent; Ethanol can be used as a selective solvent dispiet of its low ORAC value; Microwave can increment the temperature in a short period of time avoiding early degradation.

Ethanol/water is the best solvent for extraction using Açaí (E. Oleracea) slurry matrix. Pure ethanol and pure water were also tested as solvents, but results showed that water is not a suitable option because any residual oil content can hamper the penetration of water into the matrix. However, it was possible to identify the improvement caused by MAE pre-treatment in slurry and seeds. In the case that MAE was applied, the time to achieve the maximum extraction yield (MEY) was reduced to $10 \mathrm{~min}$ instead of $30 \mathrm{~min}$, which is the minimum in any conventional treatment. Pure ethanol has potential as selective extraction solvent, $0.107(\%)$ against $0.188(\%)$ found for traditional Soxhlet extraction for the slurry fraction. Anyway, a non-specific solvent, as ethanol/water, shows more efficiency, especially when the objective is to enhace the anthocyanin content. Ethanol/water at $60^{\circ} \mathrm{C}$ was the best extraction condition for the slurry matrix, with a yield of $0.614(\%)$ (MAE) against 4.428 (\%) (Soxhlet characterization). In this case, the maximal yield extract was achieved using MAE as pre-treatment. Experiments also show that temperature is a relevant parameter for the extraction condition, as when it is increased by $20^{\circ} \mathrm{C}$ the time required to achieve the MEY decrease by 30 minutes. Results do not show any substantial difference between maceration extraction and macerations assisted by MAE. However, the sample treated with PMAE yielded better results attributed to the associated fast increase in temperature. Ethanol/water at $60^{\circ} \mathrm{C}$ was also the best extraction condition for pulp matrix, and the maximal yield extract was achieved using PMAE as pre-treatment.

The compounds present in the natural pulp, are expected in different concentration in açaí slurry. Moreover, each fraction has an oil content that can promote some impedance during the extraction of phenolic compounds if it is not previously removed. These oils also have a commercial interest, especially the oil obtained from the pulp, because of its high content of unsaturated fatty acids and essential oil. The main property of this oil is the antidiarrheal effects [16]. However, all studies about the characterization of Açaí berry are based on pulp or seeds content, the reason for which it is necessary to perform a specific detailed characterization of its by-products. 


\section{References}

[1] açaí in Dicionário infopédia da Língua Portuguesa, (2018). https://www.infopedia.pt/dicionarios/lingua-portuguesa/açaí (accessed July 9, 2018).

[2] D. Del Pozo-Insfran, C.H. Brenes, S.T. Talcott, Phytochemical Composition and Pigment Stability of Açai (Euterpe oleracea Mart.), J. Agric. Food Chem. 52 (2004) 1539-1545.

[3] A.G. Schauss, X. Wu, R.L. Prior, B. Ou, D. Patel, D. Huang, J.P. Kababick, Phytochemical and nutrient composition of the freeze-dried amazonian palm berry, Euterpe oleraceae Mart. (Acai), J. Agric. Food Chem. 54 (2006) 8598-8603.

[4] J. Kang, Z. Li, T. Wu, G.S. Jensen, A.G. Schauss, X. Wu, Anti-oxidant capacities of flavonoid compounds isolated from acai pulp (Euterpe oleracea Mart.), Food Chem. 122 (2010) 610-617.

[5] J. Kang, C. Xie, Z. Li, S. Nagarajan, A.G. Schauss, T. Wu, X. Wu, Flavonoids from acai (Euterpe oleracea Mart.) pulp and their antioxidant and antiinflammatory activities, Food Chem. 128 (2011) 152-157.

[6] L.A. Pacheco, Chemical characterization, bioactive properties, and pigment stability of polyphenolics in acai (Euterpe Oleracea Mart.), 2009. http://hdl.handle.net/1969.1/ETD-TAMU-2009-05-400.

[7] O. V. Zillich, U. Schweiggert-Weisz, P. Eisner, M. Kerscher, Polyphenols as active ingredients for cosmetic products, 2015.

[8] J. V. Garcia-Perez, M.A. García-Alvarado, J.A. Carcel, A. Mulet, Extraction kinetics modeling of antioxidants from grape stalk (Vitis vinifera var. Bobal): Influence of drying conditions, J. Food Eng. 101 (2010) 49-58.

[9] A. Alvarez, Development of a microwave pretreatment for the extraction of active compounds from natural byproducts, Thesis, University of valladolid, 2018.

[10] K. Sólyom, S. Kraus, R.B. Mato, V. Gaukel, H.P. Schuchmann, M.J. Cocero, Dielectric properties of grape marc: Effect of temperature, moisture content and sample preparation method, J. Food Eng. 119 (2013) 33-39.

[11] V.L. Singleton, R. Orthofer, R.M. Lamuela-Raventós, Analysis of total phenols and other oxidation substrates and antioxidants by means of folin-ciocalteu reagent, Methods Enzymol. 299 (1999) 152-178.

[12] R.T. Buratto, E.G. Hoyos, M.J. Cocero, Á. Martín, Impregnation of açaí residue 
extracts in silica-aerogel, J. Supercrit. Fluids. 146 (2019) 120-127.

[13] AOAC Official Method, Total Monomeric Anthocyanin Pigment Content of Fruit Juices, Beverages, Natural Colorants, and Wines, in: AOAC Int. 37.1.68, 2005.

[14] B. Ou, M. Hampsch-Woodill, R.L. Prior, Development and validation of an improved oxygen radical absorbance capacity assay using fluorescein as the fluorescent probe, J. Agric. Food Chem. 49 (2001) 4619-4626.

[15] F. Ganske, B.M.G. Labtech, ORAC Assay on the FLUOstar OPTIMA to Determine Antioxidant Capacity, (2006).

[16] M.J. Plotkin, M.J. Balick, Medicinal uses of South American palms, J. Ethnopharmacol. 10 (1984) 157-179. 



\section{Chapter 3}

Formulation by Impregnation of Euterpe Oleracea

Mart. (Açaí) Residue Extracts in Silica-Aerogel 
Chapter 3 


\begin{abstract}
Açaí (Euterpe Oleracea Mart.) is a berry found in Amazon Rainforest, with a high content of polyphenols and flavonoids. This work studied the formulation of bioactive compounds extracted from E. Oleracea fruit, by impregnation in silica-aerogel. Three fruit fractions were studied: pulp, seeds and slurry, and two extracts were obtained from each fraction: an oil fraction obtained by Soxhlet extraction, and a polyphenolicrich extract obtained by Pressurized Microwave-Assisted Extraction. With pulp oil, impregnation yields of $58.6 \%$ were obtained by air drying, with a surface area of 0.77 $\mathrm{m}^{2} / \mathrm{g}$, while with supercritical drying method, the impregnation yield decreased to $15.3 \%$, with a surface area of $823 \mathrm{~m}^{2} / \mathrm{g}$. This indicates a loss of oil by extraction during drying. With pulp extract, the best result was obtained using indirect wet impregnation and supercritical drying, with $16.4 \%$ of impregnation. By release assay, contents of $2.276 \mathrm{mg} / \mathrm{g}$ (aerogel) of polyphenols and $0.197 \mathrm{mg} / \mathrm{g}$ (aerogel) of anthocyanins were identified.
\end{abstract}

Key-words. Euterpe Oleracea Mart.; Silica Aerogel; supercritical $\mathrm{CO}_{2}$ dryer; microwave extraction; formulation of natural product. 


\section{Introduction}

Açaí is a black-purple berry obtained from Euterpe Oleracea mart. palm, typically found in Amazon Rainforest and actively present in the diet of Brazilians, especially in north and northeast regions. The name comes from the Tupian word yasa'I - fruit that cries - in a Brazilian Portuguese adaptation [1]. The interest in E. Oleracea fruit is related to its high content of anthocyanins, polyphenols, fatty acids, and other bioactive compounds. Polyphenols and anthocyanins are secondary metabolites of plants with remarkable properties as an antioxidant and/or natural dye activities. Some of these properties are their antioxidant, anti-inflammatory, and antimicrobial functions $[2]$.

The fruit provides health benefits, but it also causes environmental problems [3]. The açaí pulp consumption just in Pará, a Brazilian state, produces around 180 thousand ton of litter daily [4]. During the pulping process, the pulp is separated from seeds (first fraction of residue), in a second step pulp is clarified by a filter where a slurry is produced (second fraction of waste), and finally, it is characterized to certify that it is safe for consumption. When a pulp batch is considered inappropriate for consumption, it is destined to residue in its totality (third fraction of residue).

According to literature, in the pulp of Euterpe Oleracea mart. berry some important compounds are present, such as anthocyanins (cyanidin 3-glucoside; 2, pelargonidin 3-glucoside) [5,6], flavonoids (orientin, homoorientin, vitexin, luteolin, chrysoeriol, quercetin, dihydrokaempferol, isovitexin, velutin, catechin, epicatechin, pcumárico) [7,8], proanthocyanidins, and some other interesting products (vanillic, ferulic, and gallic acid) [9]. These compounds, present in the natural pulp, are expected in different concentration in açaí slurry. In the seed proanthocyanidins were basically the only polyphenol compounds identified, which have a high activity as anti-oxidants [10]. Moreover, each fraction has an oil content that can promote some impedance during the extraction of phenolic compounds if it is not previously removed. These oils also have a commercial interest because of their high content of unsaturated fatty acids (oleic acid (60\%), palmitic acid (22\%), linoleic acid (12\%), palmitoleic acid (6\%)) and essential oil [11-13]. The oil also presents some phenol acids, such as vanillin acid, in the highest proportion. The main property of this pulp oil is the anti-inflammatory [11] and antidiarrheal effects [14]. However, polyphenols and anthocyanins are susceptible to early degradation under environmental condition [15-17]. An alternative to protect 
these compounds is to recover it in a porous matrix. The impregnation of bioactive substance into a porous matrix has been applied to protect and preserve it from oxygen free radical, UV-light exposition, and, on purpose to perform drugs controlled release or/and the improvement of its bioavailability [18].

On this purpose, aerogels have been shown as an appropriate matrix to protect and release bioactive compounds [19-22]. The impregnation of active compounds is easily achieved because of the open porosity of aerogels and their large specific surface area, that allows getting a high load content during the impregnation of those substances [23-25]. Aerogels are obtained from wet-gels dried through a controlled drying process. Supercritical drying is a useful process for drying aerogels and avoiding the change of its porosity structure caused by the collapse of pores that can be caused by ambient drying. Moreover, silica aerogels are very versatile and have been studied and applied in many different fields such as aeronautics, biomedicine, construction, agriculture, among many others [26-30]. The effort on the studies of silica aerogel became from the interest on its intrinsic properties such as low thermic conductivity, high specific surface area, non-toxic and non-flammable character, and the facility on removing it from a medium [31].

In cosmetic industry, silica microspheres, that are a similar material to silica aerogels, have been applied as a versatile ingredient due to its capacity to acts as antiabrasive agent, anti-caking agent, opacifying agent, or free-flowing, gelling and thickening agent [32-34]. Because of these properties, silica contributes to the homogenous distribution of pigments in color cosmetics, even preventing the agglomeration of ingredients in the formulation, and inciting the proper placement and the long-lasting effect. Silica has been applied in many types of products, especially on skincare, oral care, hair care, and dyes, make-up (powder, lipstick, lip gloss, among many others) and in antiperspirants [35-40]. Moreover, it is frequently used as an absorbent agent due to its ability to absorb sweat, fats, and oil [36].

In addition, silica is used in the food industry as a food additive to increase the volume of a product without affecting its nutritional composition and as an antifoaming agent $[34,41]$, and in the pharmaceutical industry as drug delivery system and carrier $[24,42]$.

Considering these precedents, silica aerogels can be a promising material for application in cosmetic and food applications as substitutes of silica microspheres, with enhanced properties of surface area and capacity to incorporate and protect an adsorbed 
bioactive material. Therefore, the goal of this work is to study the use of aerogel as a carrier for bioactive extracts obtained from E. Oleracea (açaí) residue. The impregnation yield and the release of the impregnated compounds have been studied. Wet-impregnation method (directly and indirectly) was applied to introduce the bioactive compounds on the silica aerogel pores. Supercritical $\mathrm{CO}_{2}$ drying was chosen as a drying method to keep-hold the mesoporous structure present on the wet-gel [18]. Conventional Soxhlet was chosen as a conventional technique for oil extraction. Pressurized Microwave-Assisted Extraction (PMAE) was applied as intensification pretreatment on the polyphenol extraction.

\section{Material and Methods}

\subsection{Preparation of aerogel monoliths}

Silica gels were prepared using tetramethyl orthosilicate (TMOS) as the precursor. TMOS and methanol were mixed in a safe recipient where ammonium hydroxide-water was added droplet by droplet. Then, $1 \mathrm{~mL}$ of solution was transferred to cylindrical molds and covered with a film for the proper gelification. The process of gelification is fast, and in a few minutes, alcohol-gels are ready to start the ageing process, for which they are kept submerged into the solvent during 7 days in order to strengthen its structure, washing them with new solvent every 24 hours in order to remove any trace of unreacted water. (molar ratio: 1 TMOS : $3 \mathrm{MeOH}: 4 \mathrm{H} 2 \mathrm{O}: 5 \times 10-3$ $\mathrm{NH} 4 \mathrm{OH})$ [43].

\subsection{Açaí residue extract}

\subsubsection{Preparation of matrix for extraction}

Matrix preparation is specific for each fraction of residue: the first fraction (seeds) has an average diameter size of $1.2 \mathrm{~cm}$, and it had to be milled to a size of $5 \mathrm{~mm}$ (knife-mill Retsch SM100) and then dried in an oven during $48 \mathrm{~h}$ at $45^{\circ} \mathrm{C}$. The second and third fractions (slurry and pulp, respectively) were frozen at $-80^{\circ} \mathrm{C}$ and then lyophilized (Telstar LyoQuest) during $72 \mathrm{~h}$.

\subsubsection{Oil extraction}


A known mass of each fraction was placed in an extraction thimble and placed at a Soxhlet apparatus, wherein hexane was applied as solvent to remove the oil content in each fraction, for $8 \mathrm{~h}$, with 5 cycles of Soxhlet reflux per hour. After extraction, hexane was evaporated under vacuum. The initial and final mass of the sample are measured in order to determine the percentage of oil content in each fraction.

\subsubsection{Polyphenol extraction}

Maceration and Pressurized Microwave-Assisted Extraction (PMAE) were applied as extraction technique and as pre-treatment for extraction, respectively. Ethanol/Water (1:1) was used as solvent for the extraction, and citric acid as $\mathrm{pH}$ regulator. Extracts were characterized in terms of extraction yield, total polyphenols content (TPC), total Anthocyanins contents (TAC), and antioxidant activity by oxygen radical absorbance capacity (ORAC). HPLC was used to determine the extract composition. Hydro-ethanol extracts were purified using Dioxan HB20 activated by methanol $(1 \% \mathrm{HCl})$. Hexane extracts were purified using a vacuum drier.

\subsection{Wet impregnation}

\subsubsection{Indirect wet impregnation}

In the indirect wet impregnation method, after the ageing process, alcohol-gels were transferred to different recipients containing the impregnation solutions of each extract fraction, keeping them there for 72 hours, during which the solution was replaced every $24 \mathrm{~h}$. Moreover, ethanol and methanol were tested as an impregnation solvent, and oil extract from the pulp by hexane was compared with an oil sample extracted from the pulp by supercritical carbon dioxide.

\subsubsection{Direct wet impregnation}

In this method, the extract obtained was added directly during sol-gel preparation, adding it to the solvent employed during the process.

\section{4. $\mathrm{CO}_{2}$ supercritical drying}


The drying process was described in detail by SING et al. and RIGBY et al. $[45,46]$. Briefly, the drying process took place in a closed circuit, including a buffer of $\mathrm{CO}_{2}$, the chamber where monoliths were charged and a pump for $\mathrm{CO}_{2}$ recycling. Initially, the chamber is isolated from the rest of the system and then charged with pure solvent, keeping monoliths submerged in the solvent to avoid damages in their structure. In a second step, the buffer $(0.5 \mathrm{~L})$ is loaded with $\mathrm{CO}_{2}$, that is compressed at 120 bar and heated at $42^{\circ} \mathrm{C}$ (density $695.24 \mathrm{Kg} / \mathrm{m} 3$ ). When these conditions are achieved, the chamber is opened, and $\mathrm{CO}_{2}$ starts to flow through the system thanks to a pump. Supercritical $\mathrm{CO}_{2}$ recycling is maintained during $1 \mathrm{~h}$, thus reaching saturation of $\mathrm{CO}_{2}$ by the solvent. Then, the chamber is again isolated, $\mathrm{CO}_{2}$ from the buffer is released in order to introduce fresh $\mathrm{CO}_{2}$ into the system. Operating in this way, 3 cycles were performed in order to obtain completely dried silica aerogels. With this procedure, as the impregnated compound is not soluble in $\mathrm{CO}_{2}$, at the same time that silica is dried, the impregnated compounds precipitate in the pores of the aerogel by an antisolvent process [44].

\subsection{Aerogels characterization}

\subsubsection{Physicochemical Analysis}

Aerogels were subjected to milling and degassing at vacuum. The specific surface area and average pore diameter were then determined by adsorption of $\mathrm{N}_{2}$ at $196^{\circ} \mathrm{C}$, and calculated by BET (Brunauer, Emmett, Teller) method. Average pore volume was characterized by desorption curve of $\mathrm{N}_{2}$ (BJH method). Chemical bondstructures were analyzed by FTIR (Bruker Platino-ATR). Thermo-stability and impregnation yield was determined by Thermogravimetric (TGA) analysis.

\subsubsection{Analytic active substances}

The total content of polyphenols in the impregnation solutions was quantified in order to obtain the amount of free active substances. It was characterized in terms of total polyphenols content (TPC) and total Anthocyanins contents (TAC). HPLC was used to determine the extract composition.

\subsubsection{Total polyphenols content (TPC)}


For TPC analysis a capped test tube was used, in which $40 \mu \mathrm{L}$ of the extract, 3 $\mathrm{mL}$ of ultrapure water and $200 \mu \mathrm{L}$ of folin-ciocalteau reagent were added. It was also necessary to prepare a control sample using $40 \mu \mathrm{L}$ of extraction solvent, $3 \mathrm{~mL}$ of ultrapure water and $200 \mu \mathrm{L}$ of folin-ciocalteau reagent. Tubes were closed and homogenized at $40^{\circ} \mathrm{C}$ for 5 minutes. After this period, $600 \mu \mathrm{L}$ of $\mathrm{Na}_{2} \mathrm{CO}_{3}(20 \% \mathrm{v} / \mathrm{v})$ solution was added, tubes were vigorously stirred, and kept in hot-water-bath at $40^{\circ} \mathrm{C}$ for 30 minutes. Finally, samples were analyzed by spectrophotometry $(\lambda=765 \mathrm{~nm})$. The TPC concentration is given in Gallic acid equivalent per $100 \mathrm{~g}$ of dry material.

\subsubsection{Total Anthocyanins contents (TAC)}

The TAC analyses were performed with the aid of a spectrophotometer. Samples were diluted $(1: 4)$ in a potassium hydroxide buffer $(0.025 \mathrm{M} \mathrm{KCl})$ at $\mathrm{pH} 1.0$ and buffered with acetate trihydrate buffer $(\mathrm{CH} 3 \mathrm{CO} 2 \mathrm{Na} 3 \mathrm{H} 2 \mathrm{O} \quad 0.4 \mathrm{M})$ at $\mathrm{pH} 4.5$. Samples were diluted in both buffers solution, at $\mathrm{pH} 1.0$ and 4.5, and each solution was measured at $520 \mathrm{~nm}$ and $700 \mathrm{~nm}$. The concentration of anthocyanins in each sample is given in $\mathrm{g}$ of cyanidin equivalent per $100 \mathrm{~g}$ of dry material.

\subsection{Release}

The impregnated aerogels were subjected to a release test in order to quantify the amount of impregnated polyphenols. In addition, the anthocyanins were quantified in the case of the aerogels impregnated with the extract of the pulp. The release test consisted of subjecting a known mass of impregnated aerogel to the microwave-assisted extraction process at 1.5 bar using a known volume of solvent (Ethanol / Water $50 \% \mathrm{v} /$ $\mathrm{v}$ acidified, $\mathrm{pH}=3$ ), for 20 seconds. Subsequently, the calculation of the total polyphenol content (TPC) expressed in $\mathrm{mg}$ GAe/gaerogel and total anthocyanins in $\mathrm{mg}$ $\mathrm{AC} / \mathrm{g}_{\text {aerogel }}$ was performed, using the Folin-Ciocalteu method (section 2.5.2.1) and the $\mathrm{pH}$-differential method (section 2.5.2.2), respectively. 


\section{Results and Discussion}

\subsection{Aerogels}

According to IUPAC distribution, the adsorption-desorption $\mathrm{N}_{2}$ curve of the blank material (plotted on the Figure 1) corresponds to a hysteresis type IV [45] and isotherm H1, typically found for materials with very narrow pores, open or closed cylinders, and uniform size and distribution. The pure silica aerogel is a mesoporous material according to its pores size distribution. Moreover, this distribution is homogenous, presenting an average value of $11 \mathrm{~nm}$. The supplied pore data refers to the adsorption isotherm to avoid the pore-blocking effect that occurred during the $\mathrm{N}_{2}$ desorption due to the capillary condensation that blocks the pores and interferes with the correct determination of the texture parameters [46].

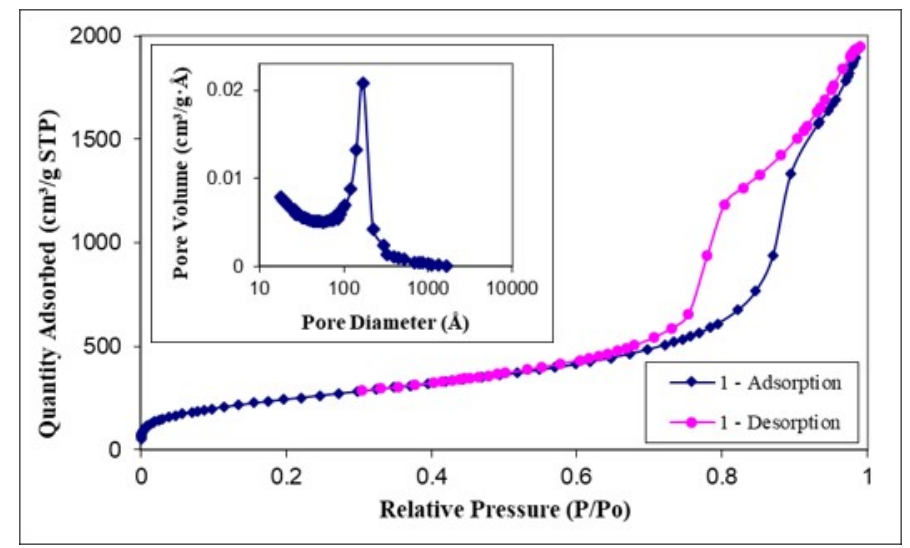

Figure 1 - Isothermal of pure silica and pore volume distribution

However, the type of impregnation (direct or indirect) and the drying method can interfere in the structure, as well as in its specific surface area, average pore volume, and, average pore diameter, as discussed in the following sections.

\subsection{Wet impregnation: preliminary assay}

Initially, wet impregnation was performed by indirect impregnation process and with low content of oil obtained from the three different residual fractions, in order to determine which solvent was the best for impregnation: methanol or ethanol. Table 1 shows a small decrease of specific surface area after impregnation of the aerogels, 
taking pure silica as a reference, which might indicate that oil content has filled some pores. Also, taking this value as an evaluation parameter, it is possible to conclude that ethanol works better as solvent for impregnation than methanol. Probably, this is related to the low solubility of this oil in methanol. By visual inspection of the aerogels, it was not observed any substantial change in color or opacity.

Table 1 - Textural properties of aerogels.

\begin{tabular}{cccccc}
\hline Extract & Fraction & Solvent & $\begin{array}{c}\text { Specific Surface } \\
\text { area }(\mathrm{m} 2 / \mathrm{g})\end{array}$ & $\begin{array}{c}\text { Average pore } \\
\text { volume }(\mathrm{cm} 3 / \mathrm{g})\end{array}$ & $\begin{array}{c}\text { Average pore } \\
\text { diameter }(\mathrm{nm})\end{array}$ \\
\hline Blank & - & - & 910 & 3.0 & 11.0 \\
Oil & Pulp & Methanol & 817 & 2.7 & 10.9 \\
Oil & Slurry & Ethanol & 835 & 2.8 & 11.2 \\
Oil & Seed & Ethanol & 859 & 2.9 & 11.0 \\
\hline
\end{tabular}

The oils obtained from slurry and from seed were impregnated following the best result obtained from pulp-oil. As it can be seen in Table 1, pore volume showed a lower reduction when it was impregnated with these oils than when it was impregnated with pulp oil, suggesting a lower impregnation yield, which may be related to differences in the composition of the three oil fractions.

The impregnated oil percentage in each fraction of residue was determined by Soxhlet extraction, using the initial and final mass employed in the Soxhlet process to calculate it. Results show that aerogels impregnated with seeds oil have $7.5 \pm 0.1 \%$, with slurry oil have $6.8 \pm 0.9 \%$ and with dry-pulp have $42.0 \pm 1.8 \%$ of oil content.

\subsection{Wet impregnation:}

The type of impregnation (direct or indirect) and the drying method can interfere in the structure, as well as in its specific surface area, average pore volume, and, average pore diameter. These data were recovered and summarized in Table 2. 
Table 2 - Textural properties of aerogels impregnated by extracts obtained from the different fractions of Açaí residue.

\begin{tabular}{ccccccc}
\hline Extract & Fraction & $\begin{array}{c}\text { Impregnation } \\
\text { process }\end{array}$ & $\begin{array}{c}\text { Dry } \\
\text { Process }\end{array}$ & $\begin{array}{c}\text { Specific Surface } \\
\text { area }(\mathrm{m} 2 / \mathrm{g})\end{array}$ & $\begin{array}{c}\text { Average pore } \\
\text { volume }(\mathrm{cm} 3 / \mathrm{g})\end{array}$ & $\begin{array}{c}\text { Average pore } \\
\text { diameter }(\mathrm{nm})\end{array}$ \\
\hline Blank & & - & SC & 910 & 3.04 & 11.0 \\
Blank & & - & Air & & & \\
Oil & Pulp & Direct & SC & 892 & 2.98 & 13.4 \\
Oil & Pulp & Indirect & SC & 848 & 2.89 & 10.9 \\
Oil & Pulp & Indirect & SC & 823 & 2.78 & 11.0 \\
Oil & Seed & Indirect & SC & 847 & 2.54 & 12.4 \\
Polyphenolic & Pulp & Direct & SC & - & - & - \\
Polyphenolic & Pulp & Direct & Air & 595 & 0.04 & 0.3 \\
Polyphenolic & Pulp & Indirect & SC & 856 & 1.80 & 9.1 \\
Polyphenolic & Pulp & Indirect & air & 830 & 0.26 & 3.6 \\
Polyphenolic & Pulp & Indirect & SC & 873 & 1.60 & 8.2 \\
Polyphenolic & Seed & Indirect & SC & 739 & 2.43 & 10.0 \\
\hline
\end{tabular}

Direct $=$ wet impregnation by Direct method; Indirect $=$ wet impregnation by Indirect method.

\subsubsection{Wet impregnation: oil extract}

The first fact to point out is the differences in the size of monoliths dried by air and by supercritical carbon dioxide. Monoliths formed were split into two groups to evaluate the effects of drying method under aerogel structure and its loaded compounds. Air drying induced pore collapsing, and as a result, monoliths are much smaller than molds (Figure 2(A-II)). In an oppositive way, monoliths dried by supercritical kept the shape and size of the pattern (Figure 2(A-I)).

The visual analysis is the first parameter to determine how successful the impregnation was. Taking the color intensity as a parameter is possible to determine that indirect impregnation (Figure 2(C-I \& C-II)) worked better than direct impregnation (Figure 2(B-I \& B-II)).

In addition, the pore diameter of those gels obtained from $\mathrm{SC} \mathrm{CO}_{2}$ drying (Table 2) and direct impregnation method $(13.4 \mathrm{~nm})$ are bigger than that of gels impregnated with the indirect method $(10.9 \mathrm{~nm})$. This is because the direct addition of extract in aerogels increased the gelification time interfering in the pore formation. Moreover, it was observed that using this method, the monoliths slowly expelled the oil, previously added, during the maturation processes.

Related to the efficiency of the drying process, a significant difference was observed on the color intensity between those samples obtained from $\mathrm{SC} \mathrm{CO}_{2}$ drying (Figure 2(B-I \& C-I)) and by natural air drying (Figure 2(B-II \& C-II)). A possible 
reason for this fact is the partial extraction of oil by $\mathrm{SC} \mathrm{CO}_{2}$, a disadvantage of $\mathrm{SC} \mathrm{CO}_{2}$ drying process that is further discussed in section 3.4.

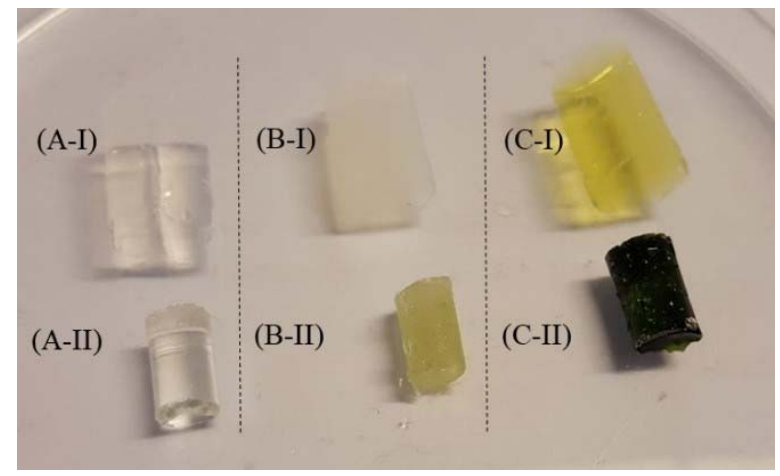

Figure 2 - Dry monoliths of silica gel impregnated with oil extract from pulp: (A) blank, (B) direct process, and, (C) indirect process; dried by (I) supercritical $\mathrm{CO}_{2}$, and (II) air.

\subsubsection{Wet impregnation: polyphenolic extract}

Anthocyanins present in the pulp polyphenolic extract are responsible for the purple color observed in the monoliths impregnated with this extract. Thus, the color can also work as a parameter to infer if the impregnation happened or not. In this way, it is possible to see in Figure 3B the difference produced by indirect impregnation, taking as comparative Figure 3A, a blank. Results presented in Table 2 also show the difference on their pore size, the difference between pores size and pore volume on blank material, $11.0 \mathrm{~nm}$, and $3.1 \mathrm{~cm}^{3} / \mathrm{g}$, and on impregnated silica aerogel, $9.1 \mathrm{~nm}$ and $1.8 \mathrm{~cm}^{3} / \mathrm{g}$. These results indicate that the polyphenols are occupying these pores or bigger pores were occupied first (low impedance on this occupation).

The color was more intense on those gels obtained from direct impregnation (Figure 3(C-II)). On this specific case, the strongest color is related to the impossibility of aging process deriving from the direct impregnation did not allow the monoliths gelification, even after several hours. Reason for this is that this batch was just air-dried and the maturation period did not occur. As results, this batch changed its type of porosity, as indicated by results in Table 2 , becoming a microporous material with a pore size of $0.3 \mathrm{~nm}$, and volume of a pore of $0.04 \mathrm{~cm} 3 / \mathrm{g}$. The shape obtained is also unusual, due to the air-drying happening inside the mold, and thus, the contraction of 
monoliths resulting from pore collapsing happened only in the horizontal direction. The gelification problem is also related to the change of reagents ratio.

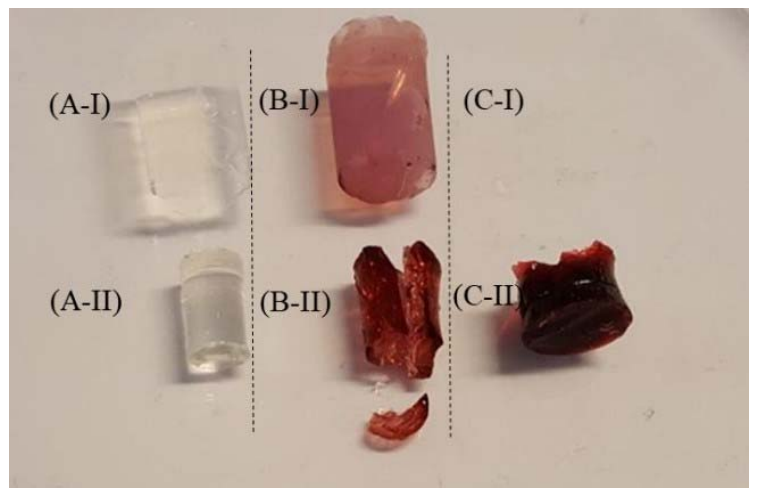

Figure 3 - Dry monoliths of silica gel impregnated by extract from pulp by ethanol/water: (A) blank, (B) direct process, and, (C) indirect process; dried by (I) supercritical $\mathrm{CO}_{2}$, and (II) air.

It is also possible to highlight the structural modification promoted by the impregnation and the dry process on the silica aerogel as mesoporous material (Figure 4). The shape of $\mathrm{N}_{2}$ adsorption isotherms is affected by the size and geometry of porous material. In this way, it is possible to classify the material according to its isotherm. The impregnated material, obtained by $\mathrm{SC} \mathrm{CO}_{2}$ drying shows the same type of isotherm that was observed in pure silica, H1. However, its curve is more pronounced, denoting a smaller pores size. This result is related to pores occupation by polyphenols.

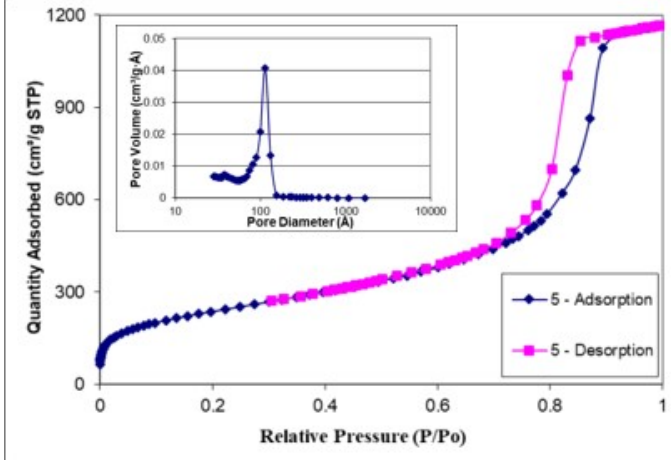

(I)

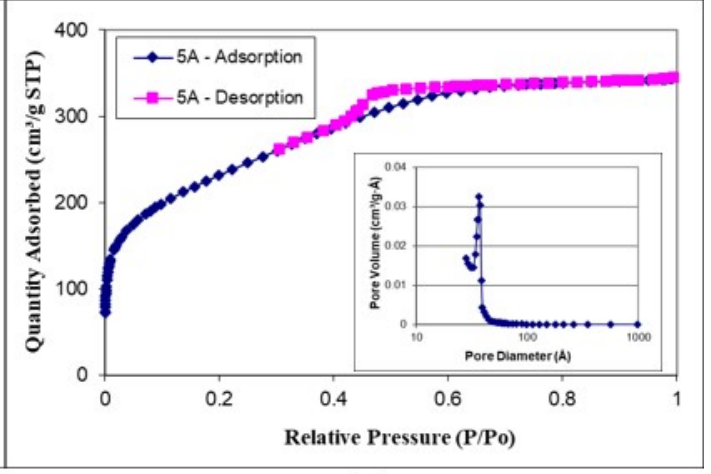

(II)

Figure 4 - Isothermal and pore volume distribution of silica aerogel impregnated with polyphenolic pulp dried by (I) supercritical $\mathrm{CO}_{2}$, and (II) air. 


\subsection{Thermo-stability of materials}

The thermostability of pure silica aerogel (support material) and the impregnated material can be analyzed by the temperature of onset in the thermogravimetric analysis. The polyphenolic extracts of seed and slurry can be considered stable until $140^{\circ} \mathrm{C}$ and $170{ }^{\circ} \mathrm{C}$, respectively. Pulp extract has no thermostability observed. This is because cyanidin, the main anthocyanin present in Açaí extract, has been reported as thermostable only below $30^{\circ} \mathrm{C}$ [17]. The pulp oil shows thermostability until $315^{\circ} \mathrm{C}$ that may be caused by the extraction process, as when the oil is recovered by vacuum evaporation it loses its volatile fraction. The same result was observed with the oil obtained from the other fractions. The fixed oil mass is represented by $42 \%$ in dry mass of pulp fraction, $3.5 \%$ of seed fraction, and $1.2 \%$ of the slurry fraction.

The silica support is thermostable until $380^{\circ} \mathrm{C}$, and it is basically inert until this temperature. There is a significant mass loss at $560^{\circ} \mathrm{C}$, around $10 \%$, and a subsequent loss at $760^{\circ} \mathrm{C}$ with a small mass loss of $4 \%$. Thus, the total loss of mass is $14 \%$.

In addition, the phenolic extract from the pulp had improved thermostability when it was impregnated in the support, achieving a maximum thermostability of $270^{\circ} \mathrm{C}$ when indirect impregnation method was applied. A similar improvement was observed when seed polyphenolic extract was impregnated at the same condition, $275^{\circ} \mathrm{C}$. In opposition, under the same conditions, the thermo-stability of oil extract impregnated decreased to $235^{\circ} \mathrm{C}$.

\subsection{Impregnation yield and release assay}

\subsubsection{Oil Extract}

Total mass impregnated can be given by the difference between the residual mass in an impregnated sample and the remaining mass in the blank. Following this, the total impregnated mass is given in percentage in Table 3. 
Table 3 -Impregnation yield and total polyphenol content released.

\begin{tabular}{|c|c|c|c|c|}
\hline $\begin{array}{c}\text { Extract } \\
\text { impregnated }\end{array}$ & $\begin{array}{l}\text { Impregnation } \\
\text { method }\end{array}$ & $\begin{array}{c}\text { Dry } \\
\text { process }\end{array}$ & $\mathrm{Wt} \%$ & $\begin{array}{c}\text { Polyphenols } \\
\text { release } \\
\text { (mg GAe/gaerogel) }\end{array}$ \\
\hline \multirow[t]{2}{*}{ Pulp Oil* } & Direct & $\mathrm{SC}$ & 9.1 & 0.229 \\
\hline & & Air & 13.5 & \\
\hline \multirow[t]{2}{*}{ Pulp Oil** } & Indirect & $\mathrm{SC}$ & 12.9 & 0.120 \\
\hline & & Air & 37.5 & \\
\hline \multirow[t]{2}{*}{ Pulp Oil*** } & indirect & $\mathrm{SC}$ & 15.3 & 0.317 \\
\hline & & Air & 58.6 & 0.191 \\
\hline
\end{tabular}

According to the results in table 3, direct impregnation, which caused a slow gelification, led to a smaller impregnation yield than indirect impregnation. During the release assay, those aerogels impregnated by direct method had a low release concentration of polyphenols even having the highest concentration of oil-impregnated. This result is attributed to a low gelification of monoliths. Another fact that also contributed here was that during the maturation step oil was slowly expelled out of the pores.

With the indirect impregnation method, an increase in the oil concentration during the impregnation produced a higher impregnated yield. This is related to the high capacity of silica to absorb oil. In addition, samples dried by air and by supercritical fluids show a high difference in impregnation yield. This may be caused by the type of deposition of oil extract inside the pores. The polyphenols in the oil extract have hydroxyl groups which can perform bonds with the Si-O structure of the aerogel, while fatty acids are usually linked in a triglycerides groups, which are unable to achieve a similarly strong bond with the aerogel matrix. Despite the loss produced by the drying process, removing part of content impregnated, the release assay has shown that the amount of polyphenols released was proportional to the initial concentration and it was not affected by the SC drying.

According to TGA analysis, the maximum yield of impregnation, $58.6 \%$, was attained when indirect impregnation and air drying were applied. In the same batch, those monoliths dried by SC drying had a yield of impregnation around $15 \%$. On the other hand, the air-drying method affects the porous structure, resulting in the pores collapsing.

The loss of SC- $\mathrm{CO}_{2}$ soluble compounds on impregnated yield depends on the amount of $\mathrm{SC}-\mathrm{CO}_{2}$ used in the drying process; however, decreasing this amount can 
affect the dry efficiency and promotes residual alcohol in the aerogel. The ratio was kept constant at $0.0347 \mathrm{Kg} \mathrm{CO}_{2} / \mathrm{g}$ of dry aerogel per cycle.

\subsubsection{Polyphenol extract}

According to TGA data presented in Table 4, the maximum impregnation yield was $16.4 \%$ attained with indirect impregnation and SC drying method. Increasing the concentration of the initial solution did not affect the impregnation yield but decreased the impediment of bioactive substances in occupying the pores resulting in a color change, as observed in Figure 5. Moreover, the release assay can confirm it by the increase of polyphenols and anthocyanins released. The released data are related to the amount absorbed. The higher concentration of loading solution leads to higher loadings. This may be due to a higher amount of solute inside the pores rather than increased adsorption.

Monoliths obtained with direct impregnation could not gelify properly and then were dried just by air and with no maturation time. This process changes the structure of the material, converting it in a microporous material. The impregnation yield was not affected by this event, but it did affect the capacity of aerogels to release the impregnated content.

The impregnation of mesoporous silica aerogel allowed to increase the thermostability of extract from $30^{\circ} \mathrm{C}$ to $270^{\circ} \mathrm{C}$, with the indirect method. A similar thermostability was observed with both drying processes. Though it was observed, in the same batch, a slight tendency of higher values in those samples produced by supercritical fluid drying, with a variation of $\pm 10^{\circ} \mathrm{C}$ in onset temperature. However, the impregnation method was significant. Those samples produced with the direct method present substantially smaller thermostability than those impregnated with indirect method: $270^{\circ} \mathrm{C}$ and $195^{\circ} \mathrm{C}$, respectively. This is related to water present in the sol-gel process. In this process, a hydro-gel is first produced, and during the maturation time, water $-\mathrm{OH}$ groups are replaced by the alcohol $-\mathrm{OH}$ groups, becoming alcohol-gel. Herein these samples, directly impregnated, had not gelified properly, making impossible the maturation step and the proper formation of an alcohol-gel. This may interfere with the linking between $\mathrm{Si}-\mathrm{O}$ and polyphenol, reducing the thermo-stability. 
Table 4 - Impregnation yield of polyphenolic extract and total polyphenol and anthocyanin content released.

\begin{tabular}{|c|c|c|c|c|c|c|}
\hline \multirow{2}{*}{$\begin{array}{l}\text { Impregnation } \\
\text { method }\end{array}$} & \multirow{2}{*}{$\begin{array}{c}\text { Dry } \\
\text { process }\end{array}$} & \multirow{2}{*}{$\begin{array}{l}\text { Wt } \\
\%\end{array}$} & \multicolumn{2}{|c|}{ Initial concentration } & \multicolumn{2}{|c|}{ Released concentration } \\
\hline & & & $\begin{array}{l}\text { Polyphenols } \\
\text { (mg GAe/L) }\end{array}$ & $\begin{array}{c}\text { Anthocyanins } \\
\text { (mg AC/L) }\end{array}$ & $\begin{array}{l}\text { Polyphenols } \\
\left(\mathrm{mg} \mathrm{GAe}_{\text {Aerogel }}\right)\end{array}$ & $\begin{array}{l}\text { Anthocyanins } \\
\text { (mg AC/ } \text { g Aerogel }\end{array}$ \\
\hline direct & Air & 11.0 & - & - & 0.708 & 0.034 \\
\hline Indirect & $S C$ & 16.4 & 527.4 & 24.3 & 1.391 & 0.042 \\
\hline Indirect & $S C$ & 16.4 & 1547.8 & 72.1 & 2.276 & 0.197 \\
\hline
\end{tabular}

$\mathrm{SC}=$ Supercritical; $\mathrm{GAe}=$ Gallic Acid equivalent; $\mathrm{AC}=$ Anthocyanin Content

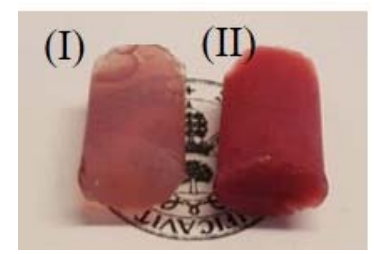

Figure 5 - Dry monoliths of silica gel impregnated by extract from the pulp by ethanol/water: (I) Low concentration, and (II) high concentration.

\subsection{FTIR Analysis}

In the analysis of pure extract, it is observed a large band between 3200-3400 $\mathrm{cm}^{-1}$ related to stretching of $-\mathrm{OH}$ polymeric chains. At $1650 \mathrm{~cm}^{-1}$ there is a peak associated with $\mathrm{C}=\mathrm{C}$ from the aromatic chain. Moreover, there was observed a weak signal at $1440 \mathrm{~cm}^{-1}$, attributed to the deformation of $\mathrm{C}-\mathrm{H}$, and at the range of 1000-1100 $\mathrm{cm}^{-1}$, corresponding to $\mathrm{C}-\mathrm{O}$ stretching bond from phenol [47,48]. These bands are characteristic of polyphenols from the extract. In addition, some authors had related them with anthocyanins [49,50]. Moreover, two more weak peaks were observed: a stretching vibration related to the linear C-H2 at $2896 \mathrm{~cm}^{-1}$ and at $2976 \mathrm{~cm}^{-1}$.

Pure Silica Aerogel (Figure 6- III) has a weak band at $3500-3400 \mathrm{~cm}^{-1}$, that is related to stretching of $-\mathrm{OH}$ that can be related to residual water or alcohol. In the low part of spectra, it is possible to observe some peaks at $1084 \mathrm{~cm}^{-1}, 812 \mathrm{~cm}^{-1}$, and $458 \mathrm{~cm}^{-}$ ${ }^{1}$ related to Si-O-Si stretching, bending, and vibration, respectively [51]. Finally, at 971 $\mathrm{cm}^{-1}$, there is a stretching band vibration of Si-O in terminal groups [52].

All those peaks present in the FTIR of pure extract were identified in the impregnated material in different intensity, excluding those under $1300 \mathrm{~cm}^{-1}$, covered by silica signal. This is another evidence of the impregnation happen and of the successful incorporation of the compounds present in the extract into the aerogel pores. 


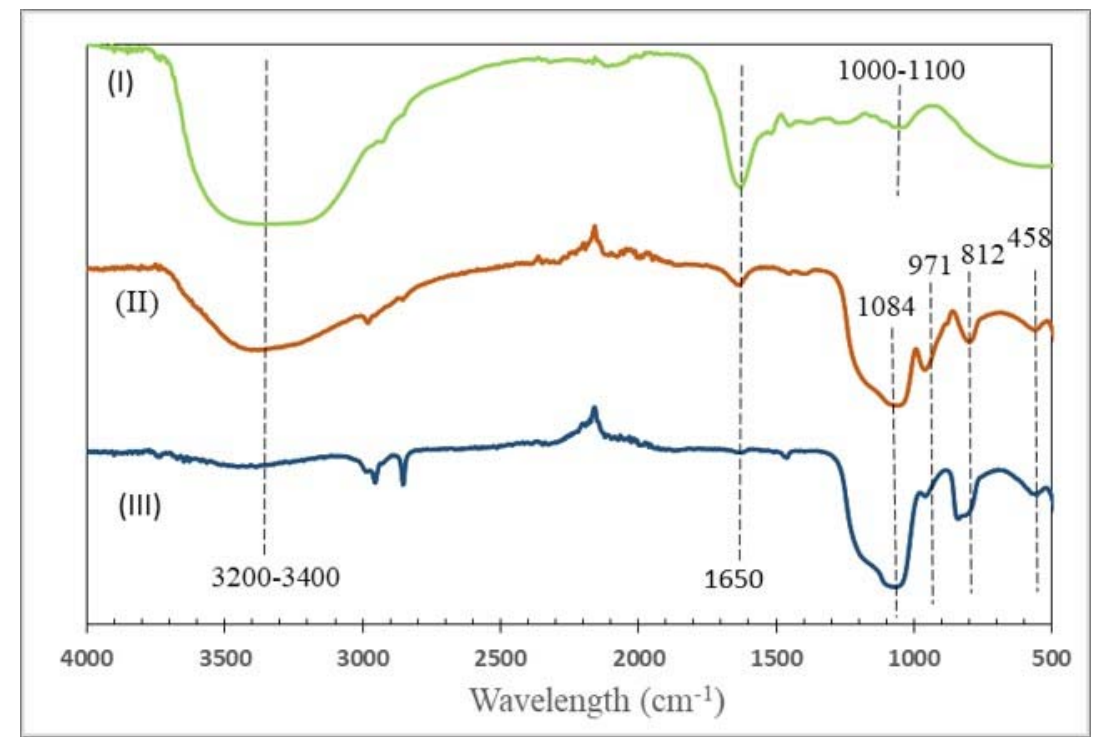

Figure 6 - FTIR spectra of (I) pulp extract, (II) silica aerogel impregnated by pulp extract, and (III) pure silica aerogel.

In the FTIR spectra of oil extract (Figure 7-IV), it is observed a small peak between $3200-3400 \mathrm{~cm}^{-1}$ related to stretching of $-\mathrm{OH}$ groups present in polyphenols. Its intensity is smaller than was observed for polyphenolic extract because it is not the main component in oil. On graphic 6-II, it overlaps with a peak near to $3470 \mathrm{~cm}^{-1}$ produced by an excess of water in this sample, consequence of the drying method employed.

Moreover, it was possible to observe in the extract a peak nearly to $3000 \mathrm{~cm}^{-1}$ related to alkene groups stretching vibration $(\mathrm{C}=\mathrm{C}-\mathrm{H})$ attributed to unsaturated fatty acids. In this same area, there is a strong peak at $2935 \mathrm{~cm}-1$ related to $-\mathrm{CH}$ vibration in alkanes. At $1750 \mathrm{~cm}^{-1}$ there is an intense peak related to the carbonyl starching of phenolic acids. At $1448 \mathrm{~cm}^{-1}$, there is a peak related to starching of $-\mathrm{CH}=\mathrm{CH}$ - present in aromatic chain. At $1162 \mathrm{~cm}^{-1}$ a peak related to C-O vibration and at $728 \mathrm{~cm}-1$ a peak attributed to $\mathrm{C}-\mathrm{H}$ deformation, both pertaining to carboxylic acid [53]. All these peaks confirm the presence of saturated and unsaturated fatty acids. Also, it can be highlighted the presence of phenolic acid such as vanillic acid [54]. In addition, there is no difference between IR spectra resulting from pulp oil and seed oil analysis, and they present the same main composition.

The peak attributed to stretching of $\mathrm{C}=\mathrm{O}$, present in phenolic acids, is present in both impregnated material (Figure 7(II\& III)), pointing out that the impregnation happened. In the spectra of the air-drying sample (Figure 7-II), it can be seen that fatty 
acids were also successfully impregnated in the silica pores (peak at $1750 \mathrm{~cm}^{-1}$ ). In another hand, peaks related to fatty acids, such as $3000 \mathrm{~cm}-1(\mathrm{C}=\mathrm{O}), 2935 \mathrm{~cm}^{-1}(\mathrm{O}-\mathrm{H})$, $1448 \mathrm{~cm}^{-1}(-\mathrm{CH}=\mathrm{CH})$, and, $1370 \mathrm{~cm}^{-1}(\mathrm{C}-\mathrm{H})$, are not present in the impregnated material after sc-drying; confirming the loss of the fatty acids during the SC-drying. In Figure 7 silica bands hide the signal related to phenolic acids lower than $1300 \mathrm{~cm}^{-1}$.

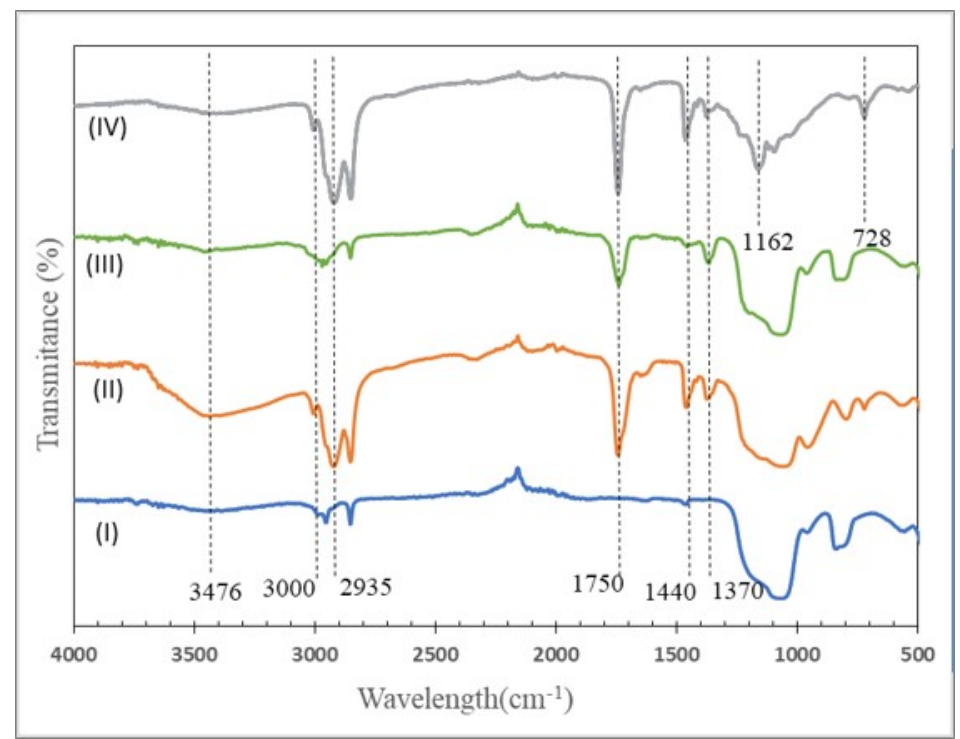

Figure 7 - FTIR spectra of (I) pure silica aerogel, (II) silica aerogel impregnated by Pulp Oil, dried by air, (III) silica aerogel impregnated by Pulp Oil, dried by SC and (IV) pulp oil extract.

\subsection{Seed extracts indirectly impregnated}

Seed oil and polyphenolic extract were impregnated following the best impregnation methods observed for pulp extracts.

Seed phenolic extract also presents a color caused by tannins, which gave a light pink tone to aerogels impregnated. As in previous experiments, the color can be pointed as indicative of successful impregnation. The maximal yield was achieved by indirect impregnation method and SC-drying, $29.3 \mathrm{wt} \%$, applying a solution of 825.2 $\mathrm{mg} \mathrm{GAe} / \mathrm{L}$. In the release assay, $5.639 \mathrm{mg} \mathrm{GAe} / \mathrm{g}$ aerogel were released.

Oil extracted from seed has a low content of phenolic compounds responsible for the pigmentation of extracts. For this reason, impregnated gels do not show an intense color. The maximum yield obtained was $29.3 \mathrm{wt} \%$ by the indirect method, while by SC-drying, the yield was $6 \mathrm{wt} \%$. 
Functional groups observed in seed extracts are equivalent to those found in pulp extracts, producing similar FTIR spectra. Both seed extracts were successfully impregnated in gels, as expected from the results of pulp impregnation. Seed oil was removed during the SC-drying process.

\section{Conclusions}

In this work, the impregnation of extracts obtained from the residue of Açaí ( $E$. Oleracea Mart.) has been investigated using different extract fractions. The study was performed employing oil obtained by hexane solvent extraction and polyphenolic extract obtained by PMAE and purified. Direct and indirect wet impregnation methods were tested. Each batch was divided into two parts to study the influence of the drying process (supercritical drying and air-drying) under monoliths structure and its loaded material.

Supercritical drying was successfully applied for the impregnation of polyphenolic extract maintaining the pore size of the aerogels, and eliminating residual solvent. When air drying was applied, the mesoporous structure of the aerogels was lost, obtaining a microporous material. However, the supercritical drying process promoted the loss of loaded oil content because of the high $\mathrm{CO}_{2}$ solubility of some compounds of oil content such as fatty acids, although polyphenols present in the oil were not lost.

TGA analysis was used to evaluate the impregnation yield (wt $\%$ ). For oil extract, the maximum $\mathrm{wt} \%$ was $58.6 \%$ when indirect impregnation and air drying were applied, and it decreased to $15 \%$ using SC drying, which indicates the extraction of components during SC drying. The maximum impregnation yield for polyphenolic extract was achieved with indirect impregnation and SC drying method, reaching a value of $16.4 \%$. Increasing the concentration of extract did not produce a higher impregnation yield. Although the total impregnation yield was not affected by increasing the concentration of oil during the impregnation, the total phenolic content (TPC) and total anthocyanins content (TAC) analysis demonstrated higher concentrations of these compounds when the oil concentration was increased, thus 
indicating a selective impregnation of these active compounds that also results in a more intense purple color of impregnated aerogels.

The release assay results corroborate that the best method of impregnation is the indirect because a high amount of active substance was impregnated using this method even though part of the oil loaded was loss during drying. For polyphenolic extract, to increase the concentration of extract indicate a lower impediment of the polyphenols and anthocyanins in occupying the pores. These results also confirm the low affinity of polyphenols for $\mathrm{CO}_{2}-\mathrm{SC}$

From the FTIR analyses, it is observed that the active substances from the extracts were impregnated inside the aerogels. Furthermore, it can be deduced that the water contained in the alcohol-gels is not effectively removed by the wet-direct impregnation method.

\section{References}

[1] açaí in Dicionário infopédia da Língua Portuguesa, (2018). https://www.infopedia.pt/dicionarios/lingua-portuguesa/açaí (accessed July 9, 2018).

[2] O. V. Zillich, U. Schweiggert-Weisz, P. Eisner, M. Kerscher, Polyphenols as active ingredients for cosmetic products, 2015.

[3] D. de L. Gonçalves, D. do S.B. Brasil, Problemas ambientais e sustentabilidade nas várzeas da Amazônia Tocantina: um estudo no Projeto de Assentamento Agroextrativista São João Batista II, Abaetetuba, Estado do Pará, Brasil, Rev. Pan-Amazônica Saúde. 7 (2016) 89-99.

[4] V.S. Bezerra, O. Freitas-Silva, L.F. Damasceno, Açaí: produção de frutos, mercado e consumo, in: Jorn. Cietífica Da Embrapa Amapá, 2016: p. 19. http://ainfo.cnptia.embrapa.br/digital/bitstream/item/152645/1/CPAF-AP-2016Acai-producao-de-frutos.pdf.

[5] D. Del Pozo-Insfran, C.H. Brenes, S.T. Talcott, Phytochemical Composition and Pigment Stability of Açai (Euterpe oleracea Mart.), J. Agric. Food Chem. 52 
(2004) 1539-1545.

[6] A.G. Schauss, X. Wu, R.L. Prior, B. Ou, D. Patel, D. Huang, J.P. Kababick, Phytochemical and nutrient composition of the freeze-dried amazonian palm berry, Euterpe oleraceae Mart. (Acai), J. Agric. Food Chem. 54 (2006) 85988603.

[7] J. Kang, Z. Li, T. Wu, G.S. Jensen, A.G. Schauss, X. Wu, Anti-oxidant capacities of flavonoid compounds isolated from acai pulp (Euterpe oleracea Mart.), Food Chem. 122 (2010) 610-617.

[8] J. Kang, C. Xie, Z. Li, S. Nagarajan, A.G. Schauss, T. Wu, X. Wu, Flavonoids from acai (Euterpe oleracea Mart.) pulp and their antioxidant and antiinflammatory activities, Food Chem. 128 (2011) 152-157.

[9] L.A. Pacheco, Chemical characterization, bioactive properties, and pigment stability of polyphenolics in acai (Euterpe Oleracea Mart.), 2009. http://hdl.handle.net/1969.1/ETD-TAMU-2009-05-400.

[10] L. Barros, R.C. Calhelha, M.J.R.P. Queiroz, C. Santos-Buelga, E.A. Santos, W.C.B. Regis, I.C.F.R. Ferreira, The powerful in vitro bioactivity of Euterpe oleracea Mart. seeds and related phenolic compounds, Ind. Crops Prod. 76 (2015) $318-322$.

[11] H.A.S. Favacho, Phytochemical analysis and evaluation of the anti-inflammatory and antinociceptive activities of oil fixed of Euterpe oleracea, Universidade Federal do Pará, 2009. http://repositorio.ufpa.br/jspui/handle/2011/5616.

[12] C. Lubrano, J.R. Robin, A. Khaiat, Fatty acid, sterol and tocopherol composition of oil from the fruit mesocarp of six palm species in French Guiana, Oléagineux. 49 (1994) 59-65.

[13] H. Rogez, Açaí: Preparo, Composição e Melhoramento da Conservação, 2000.

[14] M.J. Plotkin, M.J. Balick, Medicinal uses of South American palms, J. Ethnopharmacol. 10 (1984) 157-179.

[15] K. Sólyom, R. Solá, M.J. Cocero, R.B. Mato, Thermal degradation of grape marc polyphenols, Food Chem. 159 (2014) 361-366.

[16] J. Alean, F. Chejne, B. Rojano, Degradation of polyphenols during the cocoa drying process, J. Food Eng. 189 (2016) 99-105.

[17] D. Wang, Y. Ma, C. Zhang, X. Zhao, Thermal characterization of the anthocyanins from black soybean (Glycine max L.) exposed to thermogravimetry, LWT - Food Sci. Technol. (2014). 
[18] A.N. Mustapa, A. Martin, L.M. Sanz-Moral, M. Rueda, M.J. Cocero, Impregnation of medicinal plant phytochemical compounds into silica and alginate aerogels, J. Supercrit. Fluids. (2016).

[19] C. Barbé, J. Bartlett, L. Kong, K. Finnie, H.Q. Lin, M. Larkin, S. Calleja, A. Bush, G. Calleja, Silica particles: A novel drug-delivery system, Adv. Mater. (2004).

[20] M.L. Etheridge, S.A. Campbell, A.G. Erdman, C.L. Haynes, S.M. Wolf, J. McCullough, The big picture on nanomedicine: The state of investigational and approved nanomedicine products, Nanomedicine Nanotechnology, Biol. Med. 9 (2013) 1-14.

[21] I.I. Slowing, B.G. Trewyn, S. Giri, V.S.-Y. Lin, Mesoporous Silica Nanoparticles for Drug Delivery and Biosensing Applications, Adv. Funct. Mater. (2007).

[22] P. Yang, S. Gai, J. Lin, Functionalized mesoporous silica materials for controlled drug delivery, Chem. Soc. Rev. 41 (2012) 3679-3698.

[23] M. Alnaief, S. Antonyuk, C.M. Hentzschel, C.S. Leopold, S. Heinrich, I. Smirnova, A novel process for coating of silica aerogel microspheres for controlled drug release applications, Microporous Mesoporous Mater. 160 (2012) 167-173.

[24] I. Smirnova, S. Suttiruengwong, W. Arlt, Feasibility study of hydrophilic and hydrophobic silica aerogels as drug delivery systems, J. Non. Cryst. Solids. 350 (2004) 54-60.

[25] C.A. García-González, M. Alnaief, I. Smirnova, Polysaccharide-based aerogels Promising biodegradable carriers for drug delivery systems, Carbohydr. Polym. 86 (2011) 1425-1438.

[26] J. Ge, M. Li, Q. Zhang, C.Z. Yang, P.H. Wooley, X. Chen, S.Y. Yang, Silica

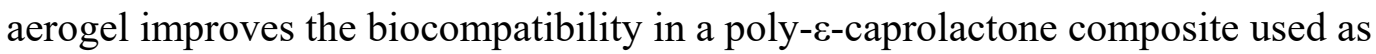
a tissue engineering scaffold, Int. J. Polym. Sci. 2013 (2013).

[27] I. Lázár, H.F. Bereczki, S. Mano, L. Daróczi, G. Deak, I. Fábián, Z. Csernátony, Synthesis and study of new functionalized silica aerogel poly(methyl methacrylate) composites for biomedical use, Polym. Compos. (2015).

[28] P.J. Reséndiz-Hernández, D.A.C. Hernández, J.M. Nonell, J.C.E. Bocardod, Bioactive and biocompatible silica/pseudowollastonite aerogels, Adv. Sci. Technol. 96 (2014) 21-26.

[29] E. Cuce, P.M. Cuce, C.J. Wood, S.B. Riffat, Toward aerogel based thermal 
superinsulation in buildings: A comprehensive review, Renew. Sustain. Energy Rev. 34 (2014) 273-299.

[30] AERSUS, La tecnología del futuro para el aislamiento térmico en el espacio, CORDIS Eur. Serv. Inf. Comunitario Sobre Investig. y Desarro. (2016).

[31] J.L. Gurav, I.K. Jung, H.H. Park, E.S. Kang, D.Y. Nadargi, Silica aerogel: Synthesis and applications, J. Nanomater. 2010 (2010) 1-11.

[32] Evonik, Silica - Technical DataSheet, Univers. Sel. Source Cosmet. Ingredients. (2017).

[33] PPG ind., Silica Products, (n.d.). http://www.ppgsilica.com/Applications/Carrierand-Free-Flow.aspx (accessed August 8, 2018).

[34] M.Z. Ali, M. Gupta, S. Daksh, Effects of Food Additives and Preservatives on Man - a Review, World J. Pharm. Life Sci. 4 (2018) 89-103.

[35] L. Fageon, R. Lorant, Cosmetic composition comprising a superabsorbent polymer and silica aerogel particles, WO2013087926A1, 2011.

[36] S. Khenniche, G. Plos, Cosmetic composition of hydrophobic silica aerogel particles and a polymer comprising a sugar unit, US20150190319A1, 2012.

[37] P. Pierre, E. Lheureux, Matt-effect composition comprising hydrophobic aerogel particles and silica particles, WO2013190104A2, 2012.

[38] C. Bebot, V. Masse, A.-S. Gras, Cosmetic composition comprising an aequeous dispersion of hydrophobic silica aerogel particles and a particular alcohol, US20150320663A1, 2012.

[39] R. Lorant, A subject matter of the present invention is a composition for topical application comprising hydrophobic silica aerogel particles and at least one emulsifying silicone elastomer. Another subject matter of the invention is a method for the cosmetic treatm, US9445985B2, 2012.

[40] S.R. Robertson, R.J. Edmundson, Novel mascara composition having very small particles, US5053221A, 1989.

[41] L.A. Rauner, Method for reducing or preventing foam in liquid mediums, 1966.

[42] U.S. Government, Code of federal regulations: Food and Drugs, the office of the federal register national archives and records administration, Washington, 1998.

[43] L.M. Sanz-Moral, M. Rueda, A. Nieto, Z. Novak, Ž. Knez, Á. Martín, Gradual hydrophobic surface functionalization of dry silica aerogels by reaction with silane precursors dissolved in supercritical carbon dioxide, J. Supercrit. Fluids. 84 (2013) 74-79. 
[44] M. Rueda, L.M. Sanz-Moral, A. Nieto-Márquez, P. Longone, F. Mattea, Á. Martín, Production of silica aerogel microparticles loaded with ammonia borane by batch and semicontinuous supercritical drying techniques, J. Supercrit. Fluids. 92 (2014) 299-310. d

[45] T. SING , K.S.W.; EVERETT, D. H.; HAUL, R. A. W.; MOSCOU, L.; PIEROTTI, R. A.; ROUQUEROL， J.; SIEMIENIEWSKA， Reporting physisorption data for gas/solid systems with special reference to the determination of surface area and porosity, Pure Appl. Chem. 57 (1985) 603619.

[46] S.P. Rigby, R.S. Fletcher, Experimental Evidence for Pore Blocking as the Mechanism for Nitrogen Sorption Hysteresis in a Mesoporous Material, J. Phys. Chem. B. 108 (2004) 4690-4695.

[47] F. R. Callejas, Tablas de Espectroscopía Infrarroja, Dep. Física y Química, UNAM. (n.d.). http://depa.fquim.unam.mx/amyd/archivero/TablasIR_24985.pdf.

[48] C. A. M. GARCÍA, Identificacíon de flavonoides con actividades antioxidantes presentes en Alchornea coelophylla (Euphorbiaceae), Univ. TECNOLÓGICA PEREIRA, Fac. Tecnol. Esc. QUÍMICA. (2014). http://repositorio.utp.edu.co/dspace/bitstream/handle/11059/4609/547869M385.p df; sequence $=1$.

[49] J.K. Ahmed, Effect of Chlorophyll and Anthocyanin on the Secondary Bonds of Poly Vinyl Chloride (PVC), Int. J. Mater. Sci. Appl. 4 (2015) 21.

[50] Â.A. Teixeira-Neto, A.L. Shiguihara, C.M.S. Izumi, M.A. Bizeto, F. Leroux, M.L.A. Temperini, V.R.L. Constantino, A hybrid material assembled by anthocyanins from açaí fruit intercalated between niobium lamellar oxide, J. Chem. Soc. Dalt. Trans. (2009) 4136-4145.

[51] Y. Özbakir, Z. Ulker, C. Erkey, Monolithic composites of silica aerogel with poly(methyl vinyl ether) and the effect of polymer on supercritical drying, J. Supercrit. Fluids. 105 (2014) 108-118.

[52] S. Aspromonte, A. Sastre, A. Boix, M.J. Cocero, E. Alonso, Optimization and modelling of the supercritical CO2deposition of CoxOynanoparticles in MCM41, J. Supercrit. Fluids. 110 (2016) 47-55.

[53] R.J. Meilunas, J.G. Bentsen, A. Steinberg, Analysis of aged paint binders by FTIR spectroscopy, Stud. Conserv. 35 (1990) 33-51.

[54] H.A.S. Favacho, Caracterização Fitoquímica E Avaliação Da Atividade Anti- 
Chapter 3

Inflamatória E Antinociceptiva Do Óleo Fixo De Euterpe Oleracea Mart., (2009) 79. 



\section{Chapter 4}

Co-precipitation of Açaí Pulp and seeds extract by Supercritical Antisolvent technology. 
Chapter 4 


\begin{abstract}
Açaí (Euterpe Oleracea Mart.) is a black-purple berry, typically found in Amazon Rainforest. E. Oleracea product is a natural phytochemical source, which shows a high content of polyphenols and flavonoids. It also presents remarkable properties as an antioxidant, anti-inflammatory, antimicrobial, and natural dye; its application is broadbased in pharmaceutical, cosmetic, and alimentary products. For these applications, it is necessary to develop a formulation that protects these active compounds from degradation and enhances its bioavailability. For this reason, in this work, the precipitation and encapsulation of Açaí extract with biopolymers by Supercritical Anti Solvent process is investigated. The influence of the key operating parameters (temperature and concentration) on the precipitation yield and product characteristics (encapsulation efficiency, particle size, and crystalline structure) is researched. The raw material was obtained from Obidos-PA-Brazil; The seeds were milled and dried, and, the pulp was lyophilized. The extractives were obtained by PMAE using Ethanol/water (50\%) acidified as a solvent; microwave works at constant potency of 300 watts until dietary 1.5bar of pressure. The extracts were characterized in terms of total polyphenols content (TPC), and antioxidant activity by oxygen radical absorbance capacity (ORAC). The SAS process was carried out by semi-continuous batch process at constant temperature $\left(40^{\circ} \mathrm{C}\right)$ and pressure $(100 \mathrm{bar})$. The study of particle morphology was carried by SEM analysis TGA and FTIR. The SAS process has promoted the particle extract micronization. SEM images allow observing the particle morphology modification that happened in encapsulation process in comparison to original extract and original PVP row material. Pluronic F-127 did not show appropriate properties as incipient for seeds extract because the experiments resulted in a plasticized-material.
\end{abstract}

Keywords: Supercritical $\mathrm{CO}_{2}$ formulation of natural product, Antioxidant, Microencapsulation, Supercritical Anti Solvent (SAS). 


\section{Introduction}

Açaí (Euterpe Oleracea Mart.) is a black-purple berry typically found in Amazon Rainforest. The fruit and seeds have remarkable properties as an antioxidant due to its high content of polyphenols, flavonoids, and, anthocyanin. Products such as flavonoids and anthocyanin are studied because of their pharmacological and natural dye potential. The seeds are the main by-product obtained during the industrial processes to extract the fruit pulp, sometimes, the pulp is considered inappropriate for the human consumption, in this case, the pulp became part of the industrial residue.

The benefits provided by polyphenols, flavonoids, and, anthocyanin convert this class of compounds in an interesting study area; these studies usually focus on the relation of antioxidant effect and its bioavailability [1]. As occurs with many other natural compounds, the application of these biochemical may be limited by their low solubility in aqueous systems. Encapsulating the antioxidant extract in a polymeric matrix for its protection is an excellent method to protect it for an earlier degradation, as well to improve its solubility and, as a consequence, its bio-disponibility [2].

The SAS (Supercritical Anti Solvent) encapsulation is a very versatile process for processing various natural and pharmaceutical compounds, with reasonable control of particle properties, and without product degradation or contamination [3]. In this process, the particle is solubilized in an organic solvent by which it has an affinity. Then, with the aid of a pump, this solution is introduced into a precipitator containing high-pressure $\mathrm{CO}_{2}$. By introducing the solution into the precipitator as a spray, the dissolving droplets mix with $\mathrm{CO}_{2}$, which acts as an anti-solvent, as it decreases the solubility of the solute relative to the solvent. In this way, the precipitation of the compound occurs due to the high supersaturation achieved [4]. Compared to precipitation techniques using liquid antisolvents, the SAS technique has the advantage that, due to the favorable properties in the supercritical medium, very high and homogeneous supersaturation can be achieved very quickly, which favors control over fluid properties. In addition, as already indicated, moderate temperatures below $80^{\circ} \mathrm{C}$ can be worked on, so the process becomes more suitable for working with sensitive substances such as products of natural origin [3].

The precipitation and encapsulation technical study apply to sensitive compounds. Thus, in previous encapsulation study, it has been shown that a viable encapsulation option is by combining two spray drying encapsulated surfactants 
(polyvinylpyrrolidone and Pluronic ${ }^{\circledR}$ F127) [5]. The main advantage of this proposal is to work at low pressure, 6 bar. On the other hand, it works with much higher temperatures, reaching $125^{\circ} \mathrm{C}$, which can cause the breakdown of the molecule. Encapsulation by vacuum drying has also been described [6]. One of the main advantages of this technique is using water as a solvent, but from the other side particles obtained were less spherical as drying process requires high temperature which may also result in degradation of the product of interest, despite working at lower temperature compared to the spray drying process. Concerning encapsulation material, there are several options described in the literature where several authors propose use of different cyclodextrins. It is also known that this class of complex tends to form a cyclodextrin inclusion complex [7], which provides specific improvements in water solubility and antioxidant activity [8,9]. The encapsulation of antioxidants in a mixture of Eudragit ${ }^{\circledR}$ E and polyvinyl alcohol [10] was also described, and solid solutions were formed between the antioxidant under study and these polymers, supported by bonds of hydrogen; thus obtaining an amorphous structure of the material, which is favorable for the improvement of bioavailability. It has also been described the production of lipid particles charged with antioxidant compounds by an emulsion freezing process [11].

In this way, the present study wants to increase its water solubility of the antioxidants obtained from açaí by-product and reduce their early degradation, promoting in this way the pulp and seeds extracts valorization. Supercritical Anti Solvent (SAS) was applied as a formulation process, helping the co-precipitation of açaí pulp and açaí seeds extracts with pluronic F-127 and PVP.

\section{Material and methods}

\subsection{Extract preparation}

Before performing the extraction process, it is necessary to prepare each matrix, which requires a different preparation protocol. The seeds were milled and dried, and, the pulp was lyophilized, and oil content is removed [12]. The raw material was obtained from Obidos-PA-Brazil. 
Maceration and Pressurized Microwave-Assisted Extraction (PMAE) were applied as extraction technique and as pre-treatment for extraction, respectively. Ethanol/Water (1:1) was used as a solvent for the extraction, and citric acid as $\mathrm{pH}$ regulator.

\subsection{Organic solution preparation}

The process begins with the preparation of the solution to be encapsulated, which was tested with different proportions between Pluronic F127 Sigma Aldrich and extract, and, PVP (Sigma Aldrich average mol wt 10000) and extract as well as pure extract. The effect of the concentration on the formation of the particles was also studied.

\subsection{SAS Preparation}

The assembly SAS plant is an important step. The reactor consists of a metallic jacketed cylinder that is continuously heated by the refluxing water of the thermostatic bath at $40{ }^{\circ} \mathrm{C}$. It has two flanges, the upper one with three main holes through which the barometer and the safety valve are connected, in the second one, the entrance of the $\mathrm{CO}_{2}$ and the solution, and in the third one, the flow, temperature, and pressure meters. In the flow flange, the outlet of $\mathrm{CO} 2$ and solvent is placed. The general scheme of the plant can be observed in Figure 1. In the $\mathrm{CO} 2$ line, after the opening valve, $\mathrm{CO} 2$ is liquefied and pump by the piston pump with the flow rate $2 \mathrm{~kg} / \mathrm{h}$. Before the chamber $\mathrm{CO} 2$ is again heated to $40 \mathrm{C}$ and introduced into the precipitator while measuring temperature and flow. The second inlet line drives the solution for encapsulation, from the baker to the precipitator, helped by a pump model chromatography (model 305 Gilson) and the flow is controlled at $2 \mathrm{~mL} / \mathrm{min}$. In the precipitator, the inlet-lines have a concentric entrance, which produces a spray effect when the solution and $\mathrm{CO} 2$ go inside simultaneously. This leads to the solubilisation of the solvent and the precipitation of particles from solution onto the filter placed at the bottom of the recipient. The process is carried out by semi-continuous batch, constant temperature $\left(40^{\circ} \mathrm{C}\right)$, and pressure $(100$ bar). A rupture disc set at 210 bars, an outlet GO-type valve and a flask that separates the $\mathrm{CO} 2$ from the residual solvent are placed at the exit of the precipitator [13]. 


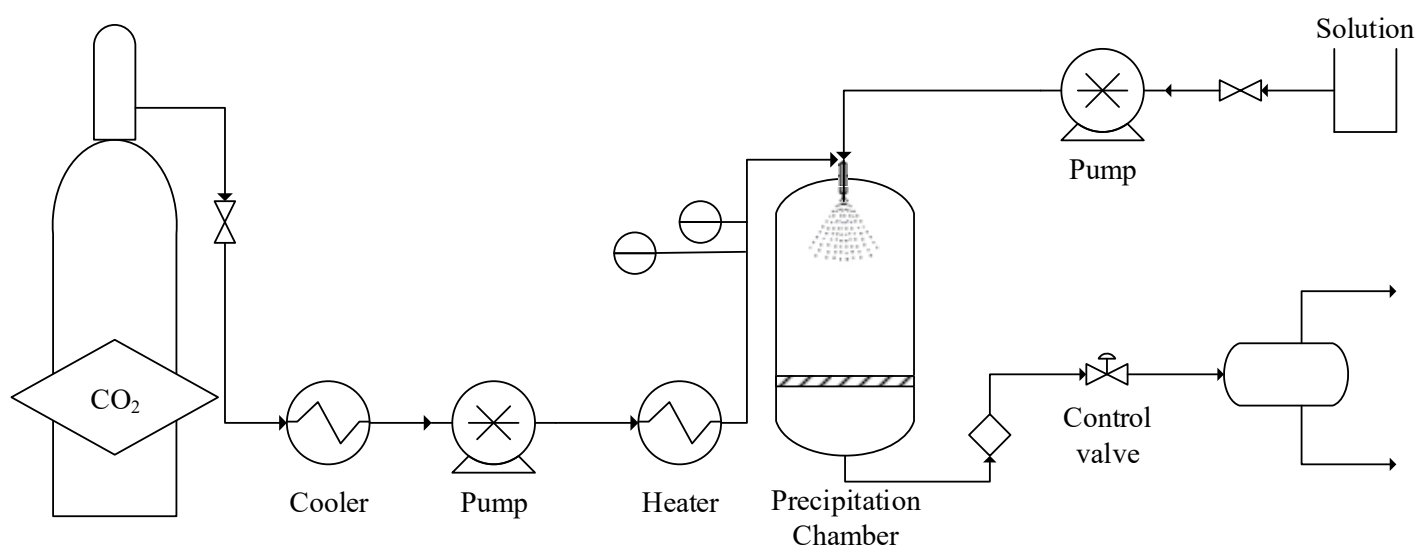

Figure 1- Complete SAS flow diagram

\subsection{Analytical procedure of obtained material}

\subsubsection{Total polyphenol content (TPC)}

For TPC analysis a capped test tube was used, adding $40 \mu \mathrm{L}$ of the extract, 3 $\mathrm{mL}$ of ultrapure water and $200 \mu \mathrm{L}$ of ciocalteau reagent. It is also necessary to prepare a control sample using $40 \mu \mathrm{L}$ of extraction solvent, $3 \mathrm{~mL}$ of ultrapure water and $200 \mu \mathrm{L}$ of folin-ciocalteau reagent. Tubes were closed and homogenized at $40^{\circ} \mathrm{C}$ for 5 minutes. After this period $600 \mu \mathrm{L}$ of $\mathrm{Na} 2 \mathrm{CO} 3(20 \% \mathrm{v} / \mathrm{v})$ solution was added, tubes were vigorously stirred, and kept in hot-water-bath at $40^{\circ} \mathrm{C}$ for 30 minutes. Finally, the samples were analyzed by spectrophotometer $(\lambda=765 \mathrm{~nm})$. The TPC concentration is given in Gallic acid equivalent per $100 \mathrm{~g}$ of dry material. [14]

\subsubsection{Total anthocyanin content (TAC)}

The TAC analyses were performed with the aid of a spectrophotometer. Samples were diluted (1:4) in a potassium hydroxide buffer $(0.025 \mathrm{M} \mathrm{KCl})$ at $\mathrm{pH} 1.0$ and buffered with acetate trihydrate buffer $\left(\mathrm{CH}_{3} \mathrm{CO}_{2} \mathrm{Na} .3 \mathrm{H}_{2} \mathrm{O} \quad 0.4 \mathrm{M}\right)$ at $\mathrm{pH}$ 4.5.

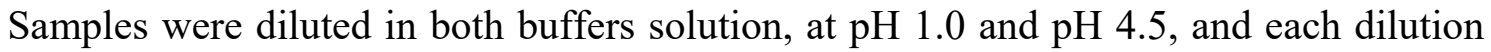
was measured at $520 \mathrm{~nm}$ and $700 \mathrm{~nm}$. The concentration of anthocyanins in each sample is given in $\mathrm{g}$ of cyanidin equivalent per $100 \mathrm{~g}$ of dry material. [15]

\subsubsection{Antioxidant activity by oxygen radical absorbance capacity (ORAC)}

For ORAC assays, in a plate suitable for use in the fluorimeter (12x8 wells) $150 \mu \mathrm{L}$ of Fluorescein Sodium salt solution $(100 \mathrm{nM})$, previously prepared in phosphate 
buffer $(\mathrm{pH} 7,4)$ was added in each used well, and, per triplicate, $25 \mu \mathrm{L}$ of blank, Trolox ${ }^{\circledR}$ (6-Hydroxy-2,5,7,8, tetra-methylchroman-2-carboxylic acid) standard, or Sample, in their designated wells. Trolox ${ }^{\circledR}$ standards were previously prepared in PBS, at different concentrations $(13 \mu \mathrm{M}, 25 \mu \mathrm{M}, 50 \mu \mathrm{M}, 100 \mu \mathrm{M}$, and, $200 \mu \mathrm{M})$. Once completed, the plate was placed inside the fluorimeter to incubate at $37^{\circ} \mathrm{C}$ for 30 minutes. After the incubation time, $25 \mu \mathrm{L}$ of 2,2-azobis(2-methylpropionamidine) dihydrochloride (AAPH) (240mM in PBS) was added in each used well. The values, obtained in this experiment, are summarized over time and given as micromol of Trolox ${ }^{\circledR}$ equivalents (TE) per $100 \mathrm{~g}$ of dry material ( $\mu$ mol TE / $g$ of dry material) [16] [17].

\subsubsection{Sample morphology}

The study of particle morphology was carried by Scanning Electron Microscopy (SEM analysis FLEX SEM 1000 Hitachi), and FTIR Bruker ALPHA FTIR spectrometer with a single sampling module of platinum ATR diffraction.

\subsubsection{Content analysis}

The purpose of this analysis is to know if the encapsulation occurred in the expected proportion. For this, a sample of pure extract was diluted in ethanol $(99.5 \%$ purity) to concentration of $10 \mathrm{ppm}$ and analysed by UV spectroscopy (spectrophotometer-UV-2550 Shimadzu), at wavelength of $275 \mathrm{~nm}$, as this value was maximum absorbance obtained by a previous spectrum scan of the sample. This was considered as a $100 \%$ extract standard. Then, solutions of the encapsulated samples were prepared using the same concentration and analysed. The results are presented in percentage.

\section{Results and Discussions}

The best results were observed when ethanol was applied as solvent and PVP as a carrier. The assays performed using acetone as solvent produced a sample with a plasticized aspect; in addition, it was observed precipitation in the initial solution. It was also determined that applied moderate heating $\left(30^{\circ} \mathrm{C}\right)$ helped in the homogenization of encapsulation solution. Different ratios of seeds-extract and PVP were processed, 
starting at the proportion of $2: 1,1: 1,1: 2$, till a maximum of 1:4; all materials encapsulated had powder aspect, however in the ratio of 1:4 the resulting material was irregular and palettized. Those proportion of seeds-extract/PVP above the rate of 1:4 resulted in plasticized material. Pulp extract and PVP were successfully processed on ratios of 2:1, and 1:1. The attempt to increase the proportion of PVP to $1: 2$, produced a resulting material plasticized. Pluronic F127 was not compatible with any extract.

\subsection{Content analysis}

Content analysis reveals that the material obtained from the processing of seeds-extracts had the expected total polyphenol content (TPC) corresponding to the encapsulated ratio; however, those materials wherein pulp-extract was applied did not present significant phenolic content besides the presence of typical color produced by anthocyanin presence. Table 1. presents the obtained results of the total phenolic content (expressed in gallic acid equivalent) in the precipitates. The original extract was processed with no polymer addition and taken as a reference to compare particle ratio formation. The original extract processed by SAS was enriched in the polyphenol content compared to the original sample that was no processed by SAS, due to the selectivity of $\mathrm{CO} 2$. During the precipitation, not all of the initial content was precipitated, as there were still remaining components in the extract that showed affinity to $\mathrm{CO} 2$ (such as residual oil). However, $\mathrm{CO} 2$ has low affinity to polyphenols that are precipitated. So the final material is particles enriched in polyphenols with respect to the initial material. It is possible to observe that performing the same ratio $(1: 1)$ the intermediate proportion (mass/solvent) could encapsulate and preserve better the extract. The same tendency was observed in other ratios (2:1) and (1:2). However, the particles formed using Pluronic F127 as carrier, were plasticized, the product was able to protect the extract which has presented good values of TPC. In addition, the single processed material was twice higher compared to starting material.

Similar to that observed with the açaí seeds extract, the pulp product also presented better results when intermediate proportions (mass / solvent) were applied. Although it was not possible to recover or perform the relevant probes at the single processed pulp extract, it was possible to compare the results with the original pulp and to observe that the processed material has lower amount of TPC than expected. Tests 
were also performed to evaluate the total content of total anthocyanins by differential buffer $\mathrm{pH}$ in spectrophotometry, none of the tested materials showed detectable anthocyanin content although all have light-pink coloration, typically induced by the presence of this substance.

Table 1 - total polyphenol content (TPC) at SAS processed material.

\begin{tabular}{|c|c|c|c|c|c|}
\hline $\begin{array}{c}\text { Extract } \\
\text { (Material) }\end{array}$ & Polymer & Solvent & Ratio & $\begin{array}{c}\text { mass/solvent } \\
(\mathrm{g} / \mathrm{L})\end{array}$ & $\begin{array}{c}\text { mg GAE/g } \\
\text { particle }\end{array}$ \\
\hline $\begin{array}{c}\text { Seeds } \\
\text { (unprocessed) }\end{array}$ & - & - & - & - & 261 \\
\hline Seeds & - & Ethanol & - & 3.33 & 500 \\
\hline Seeds & PVP & Ethanol & $1 ; 1$ & 5.00 & 78 \\
\hline Seeds & PVP & Ethanol & $1 ; 1$ & 3.33 & 211 \\
\hline Seeds & PVP & Ethanol & $1 ; 1$ & 2.50 & 80 \\
\hline Seeds & Pluronic & Acetone & $1 ; 1$ & 3.33 & 132 \\
\hline Seeds & PVP & Ethanol & $2 ; 1$ & 5.00 & 142 \\
\hline Seeds & PVP & Ethanol & $2 ; 1$ & 3.33 & 187 \\
\hline Seeds & PVP & Ethanol & $1 ; 2$ & 5.00 & 54 \\
\hline Seeds & PVP & Ethanol & $1 ; 2$ & 3.33 & 72 \\
\hline $\begin{array}{c}\text { Pulp } \\
\text { (unprocessed) }\end{array}$ & - & - & - & - & 108 \\
\hline Pulp & - & Ethanol & - & - & - \\
\hline Pulp & PVP & Ethanol & $2 ; 1$ & 3.33 & 7 \\
\hline Pulp & PVP & Ethanol & $1 ; 1$ & 5.00 & 27 \\
\hline Pulp & PVP & Ethanol & $1 ; 1$ & 3.33 & 31 \\
\hline Pulp & PVP & Ethanol & $1 ; 1$ & 2.50 & 35 \\
\hline
\end{tabular}

\subsection{Morphological study}

The morphology study was provided by Scanning electron microscope (SEM) images. The SAS process has promoted the particle seed-extract micronization. SEM images were used to analyse the differences in the morphology of the particles obtained from the single-processed seed-extract with respect to the original material. Moreover, when PVP was applied as carrier in the encapsulation process the micronization was more evident, it was possible to produce even smaller particles (Table 2). Pluronic F127 did not show good properties as a carrier for seed-extract, the experimental results in a plasticized-material. 
Table 2- comparative of SEM images of encapsulated material, PVP, seed-extract, and, seed-extracts SAS processed.

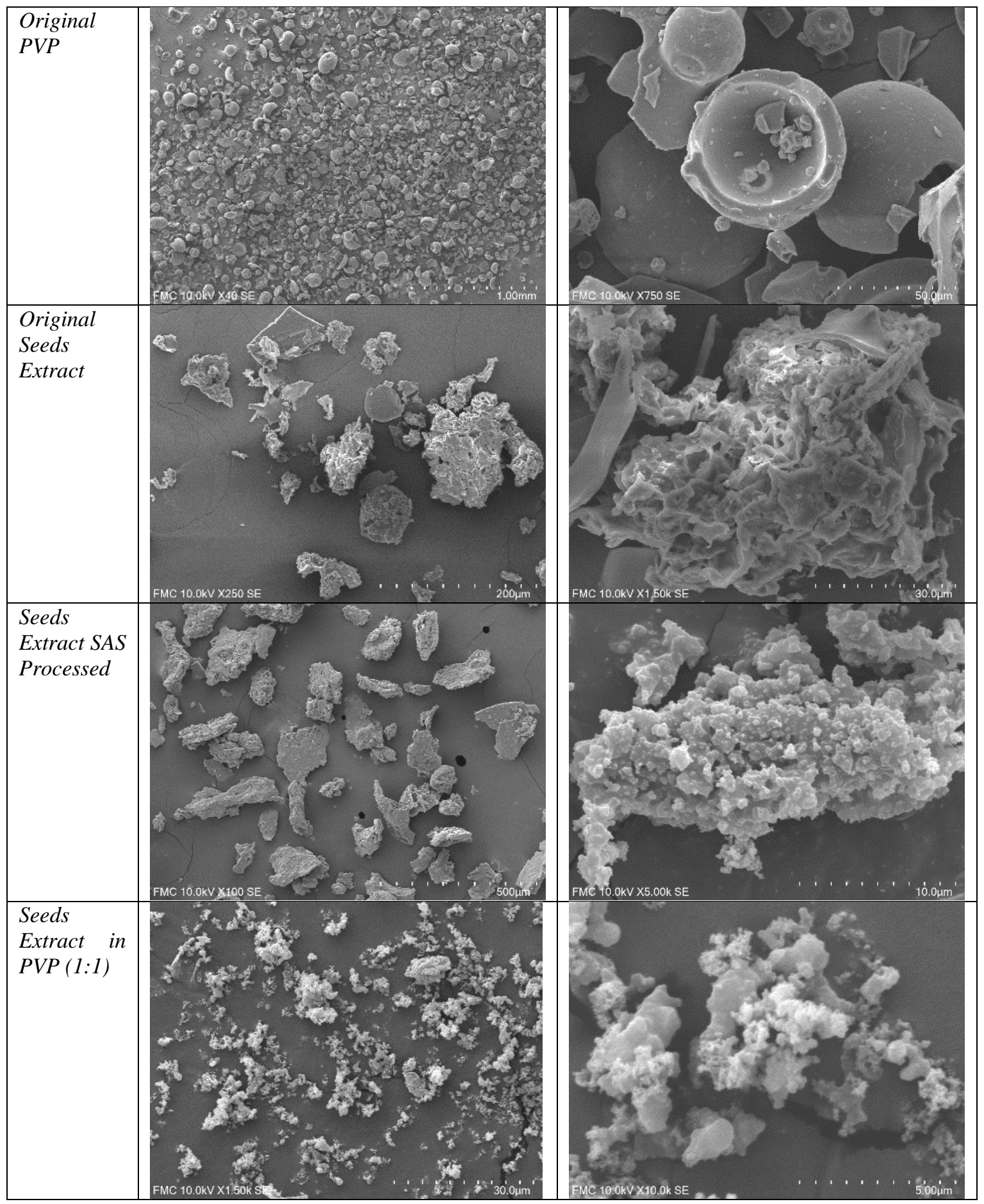

As observed from TPC analysis, the solvolvent to solute ratiois an important cariable, because an increa in the mass/solvent ratio produces an increase in the difficulty to produce the co-precipitation. The particles presented in Figure 2 have good 
co-precipitation properties, and well-covered areas. These particles were also the ones with the highest TPC value.

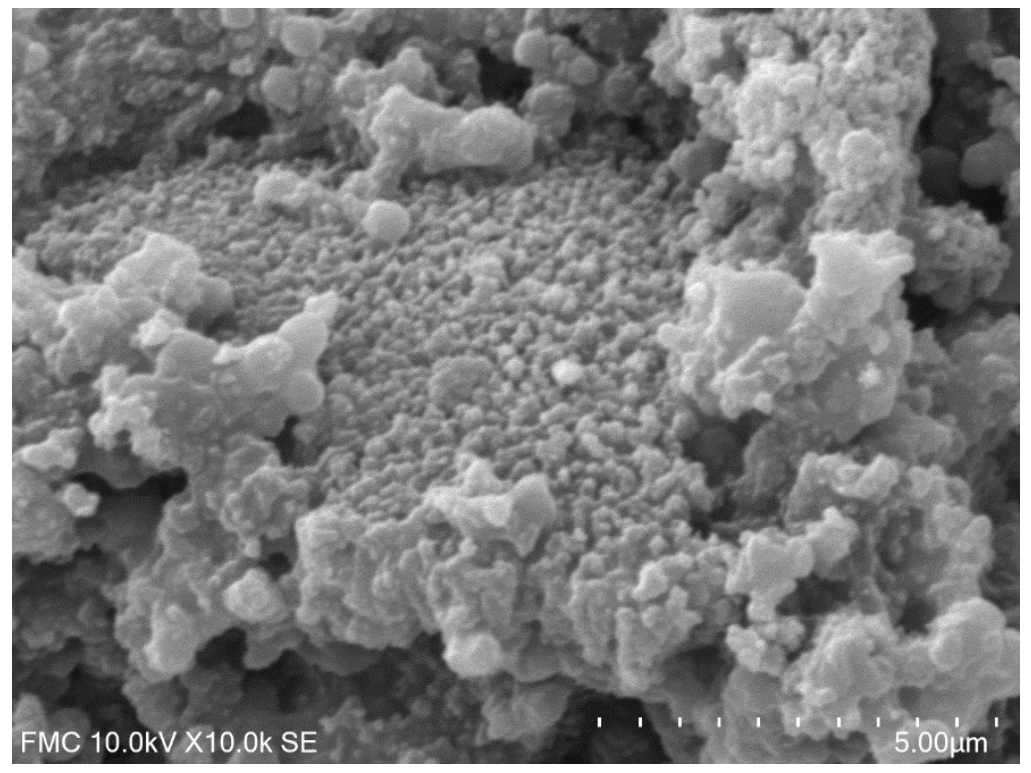

Figure 2 - Seed-extract co-precipitated with PVP at (1:1) ratio, 3.33g/L.

However, the excessive minimization of the mass/solvent ratio caused the pump to malfunction, causing blockages, which impair the constant flow pumping of suspended material. The result of the malformed content is observed in figure 3 .

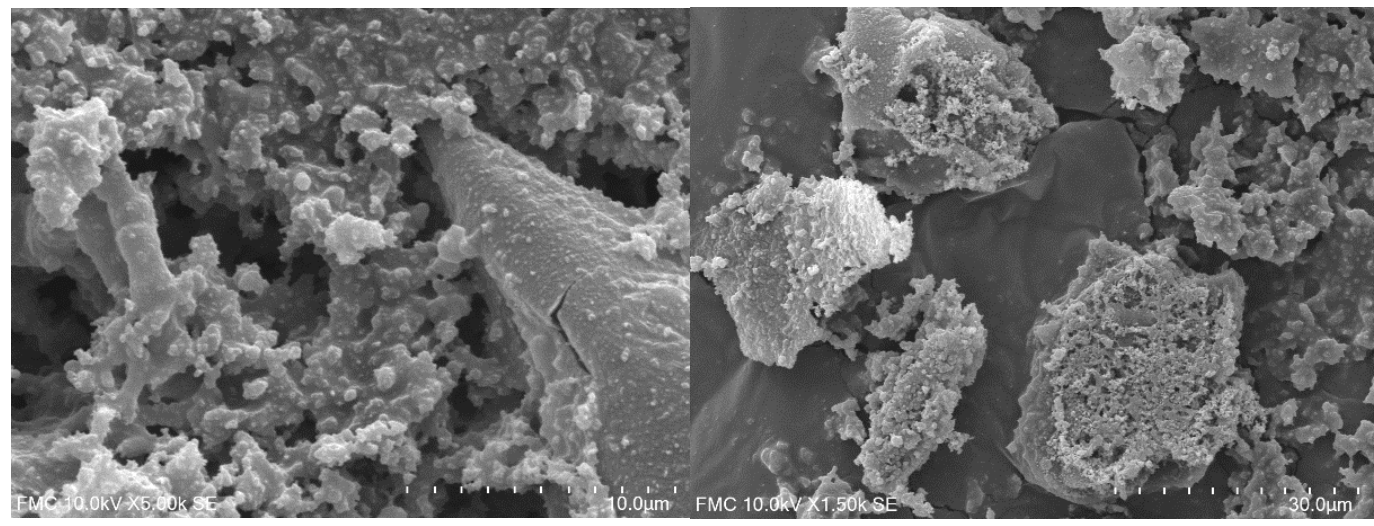

Figure 3 - Seed-extract co-precipitated with PVP at (1:1) ratio, $5 \mathrm{~g} / \mathrm{L}$.

The best concentration found was $2.5 \mathrm{~g} / \mathrm{L}$, at this solvation ratio was possible to obtain a co-precipitated material, better-distributed, less exposed areas, and small particle size. The solvation ratio changed the final particle size. 


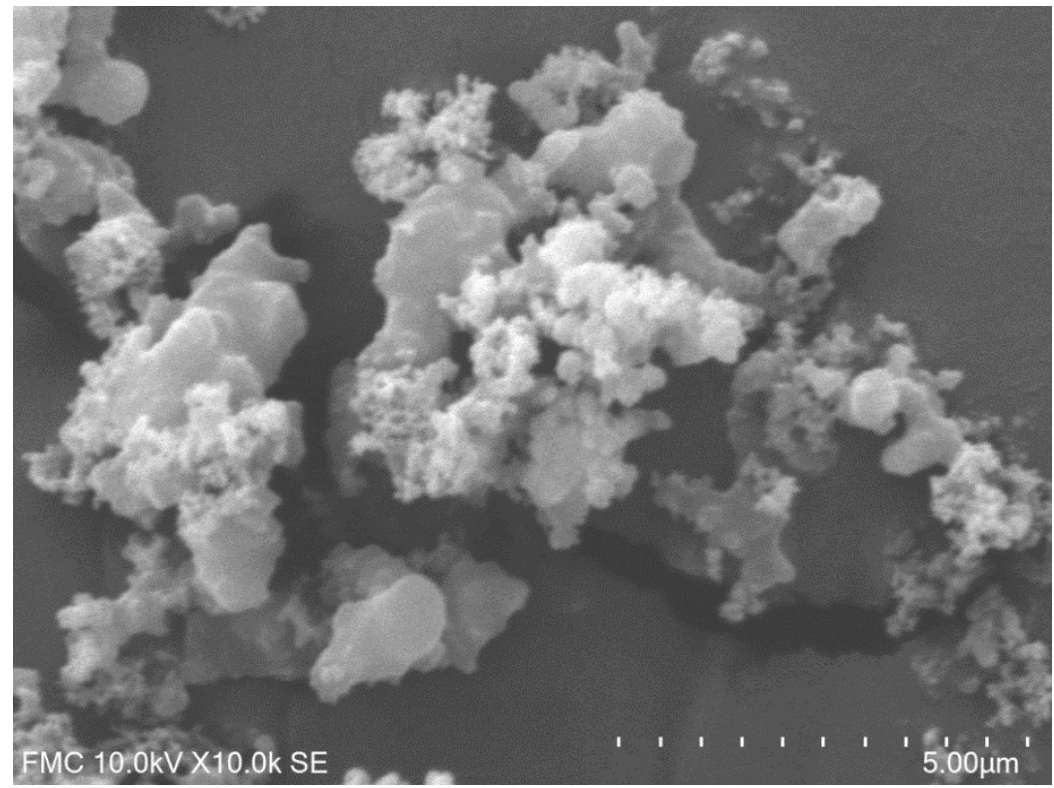

Figure 4 - Seed-extract co-precipitated with PVP at (1:1) ratio, $2.5 \mathrm{~g} / \mathrm{L}$.

When pulp-extract was single processed, without polymer, no particles were obtained, it was attributed to a strong micronization, where the particle could not be retained by the filter $(0,45 \mu \mathrm{m})$. SEM images (Figure 5) obtained through analysis of the product allowed to observe small fragments of extract inserted in the polymer. It is difficult to tell whether the material in question is within the polymer mass or if the same pattern was observed as for micronization and loss of material. Açaí pulp is a very oil material; $43 \%$ of its dry-weight is oil content. The pulp was treated to remove the oil before the extraction, but maybe there is a remained content which induced such difference between both extracts.

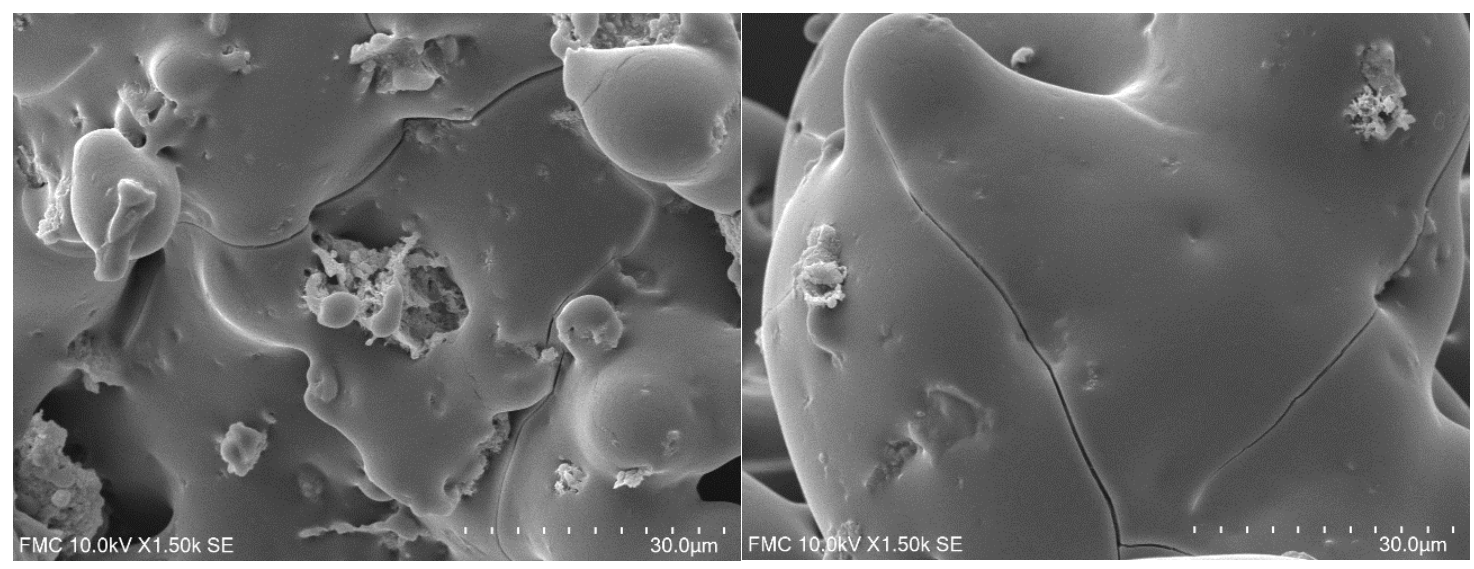

Figure 5 - Pulp-extracted and PVP processed at (1:1) ratio, (a) $5.0 \mathrm{~g} / \mathrm{L}$, and (b)3.3g/L. 


\subsection{Thermostability}

The thermostability study was made by the thermogravimetric analysis (TGA). The probe measured the loss of mass in percentage through the temperature increment. The first thermo-decay, called onset-temperature ( $T$ onset), can be taken as a comparative measurement to talk about thermostability. In this way, to increase the $\mathrm{T}$ onset is a relevant advantage of the formulation process. Seed-extract single processed (Figure 6), with no carrier addition, showed a very small loss in $\mathrm{T}$ onset concerning the original seed extract, the difference observed was around $2{ }^{\circ} \mathrm{C}$, the process achieves to increase the extract water-solubility. In the ratio of $1: 1$, the TGA obtained was similar to pure PVP, presenting a small variation in $\mathrm{T}$ onset. The material thermostability increased when more polymer was added to the process, as the T onset was higher the following gap formed between baseline and tangent was less evident, being almost imperceptible for the ratio of $(1: 2)$.

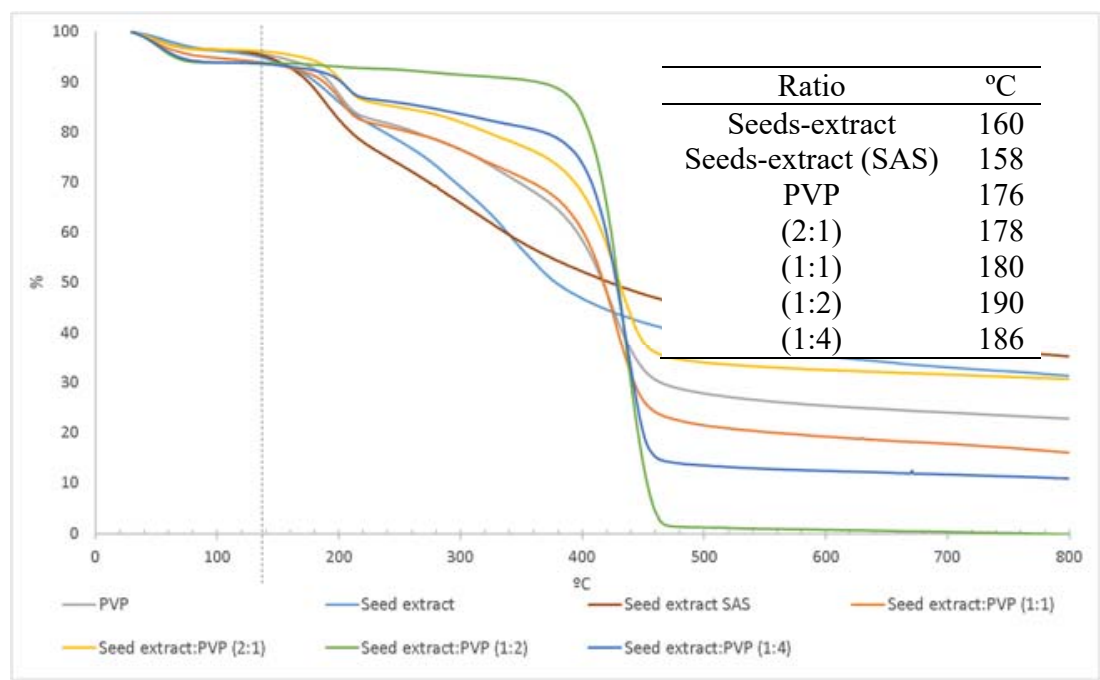

Figure 6- Thermogravimetritric (TG) curve obtained for seed-extract coprecipitated indifferent proportions with PVP.

The Derivative Thermogravimetry (DTG) is the first derivative curve obtained from TGA analysis and simulation of Differential Scan Calorimetry (DSC). This 
analytical technique makes possible to observe the precise inflection point of the TG curve, marking the point of mass changes due to vaporization or degradation. The results provided in Figure 7 showed the existence of a first peak relative to the loss of humidity, followed by two degradation peaks. It is possible to see all peaks plotted in figure 7 are simple and narrow denoting that each loss process happened in a unique step. In addition, second peaks are displaced among them denoting the soft variation in the thermostability of obtained material previously commented.

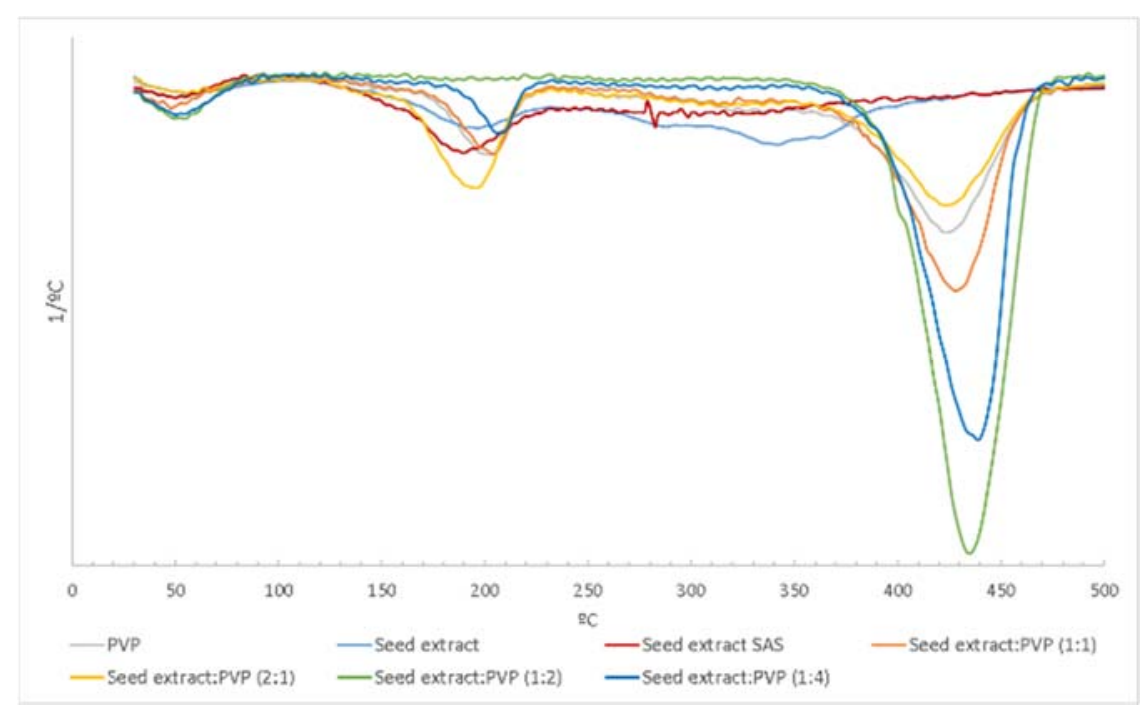

Figure 7 - Derivative Thermogravimetry (DTG) curve of co-precipitated seed-extract and PVP material.

Meanwhile, Pulp-extract had shown a different behavior when it was processed by the SAS technique. The materials obtained did not present modification on TGA or peaks displacement in DTG denoting the encapsulation was not performed successfully.

\subsection{FTIR}

The FTIR analysis of the formulated material can be compared to the source material. In both cases, the formulated material showed characteristic peaks of the source material led-extract Figure 8, and pulp-extract Figure 9. 


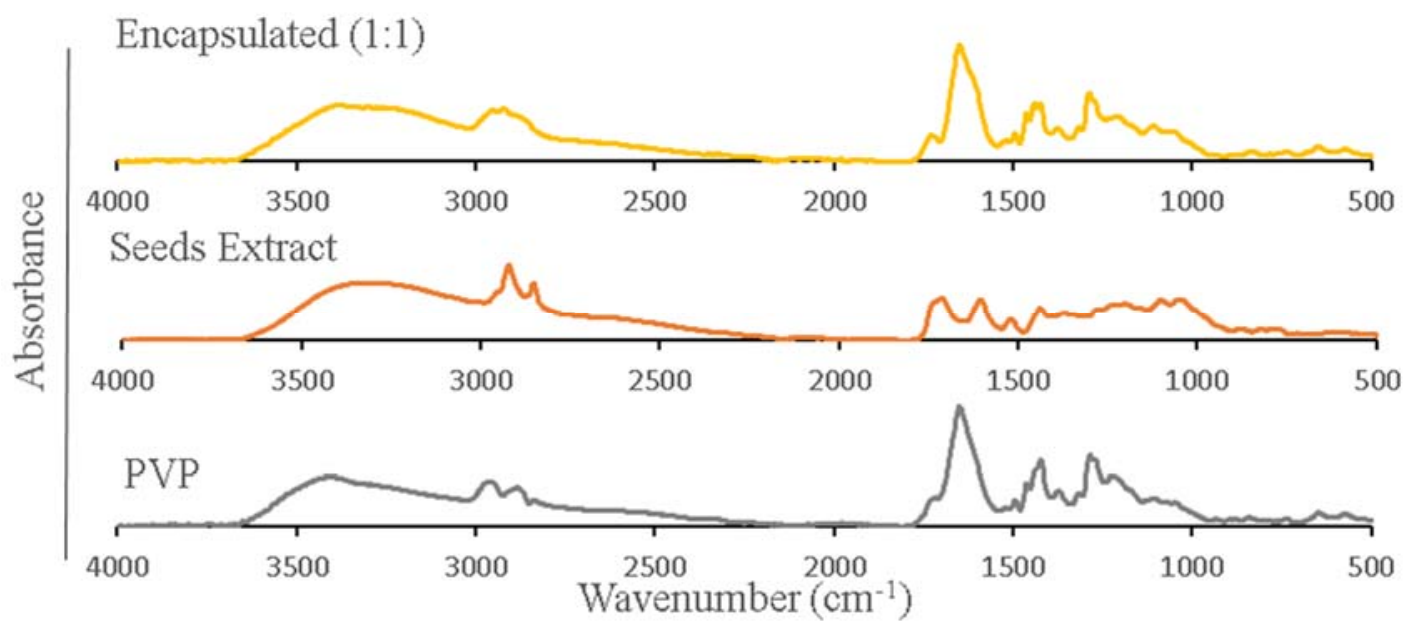

Figure 8 - FTIR of PVP, original seedes-extract, and encapsulated material: characteristic peaks of (I)seeds-extract and (II)PVP.

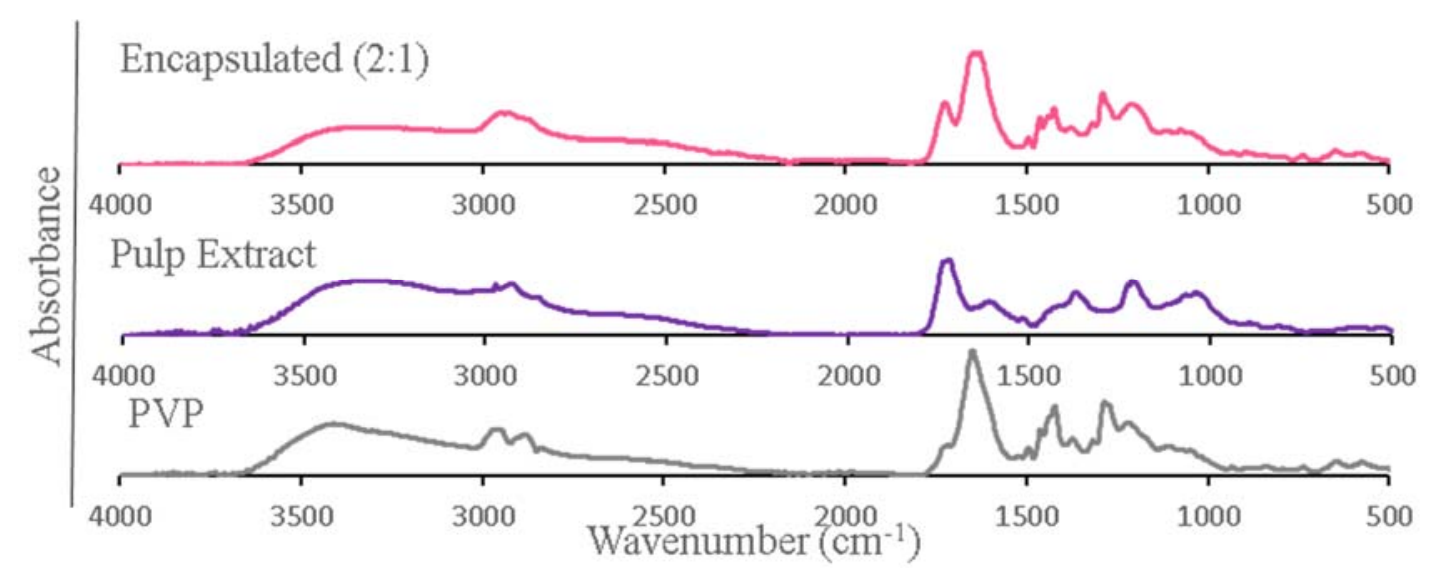

Figure 9 - FTIR of PVP, original pulp-extract, and encapsulated material: characteristic peaks of (I)pulp-extract and (II)PVP.

\section{Conclusion}

This work studied the encapsulation of active extract obtained by pressureassisted microwave extraction using as a source of extract the seeds and pulp (not suitable for consumption) of the fruit known as Açaí (Euterpe Oleracea mart). The encapsulations were tested with different polymers (PVP and Pluronic F127) and solvents (ethanol and acetone). Tests were also performed with variations of the extract/polymer and solid/liquid ratio present in the starting solution. The best results were obtained when ethanol was applied as the solvent and PVP as the encapsulating polymer. 
Among the proven extracts, the best results were presented for the material extracted from the açai seeds. The experiments in which the extract obtained from the seeds and PVP were carried out yielded viable results for the proportions (1: 1), (2:1), and (1: 2). No complete coating was achieved in any of the experiments carried out in the SAS study. When the extract to PVP ratio was increased to (1: 4), the resulting material showed particle plasticization.

The pulp extract was processed by SAS with PVP in different proportions, the resulting materials showed no significant differences between each other by mean of TG analysis. Although the precipitated content has shown the typical coloration conferred by the presence of anthocyanins, and the FTIR analysis indicated the presence of both substances (extract and PVP) on it, the materials obtained did not have a substantial total polyphenols content. In addition to the characteristic color, the FTIR analysis showed co-precipitation of the material. It was not possible to carry out a study to analyze the pulp extract processed without polymer addition, once the material could not be recovered after SAS processing.

The importance of the solid to liquid ratio on the particle formation was demonstrated within the study of seeds extract co-precipitation. This parameter not only affects the distribution of the co-precipitate but also implies the particle size.

\section{References}

[1] A. Munin, F. Edwards-Lévy, Encapsulation of natural polyphenolic compounds; a review, Pharmaceutics. 3 (2011) 793-829.

[2] D.T. Santos, M.A.A. Meireles, Micronization and encapsulation of functional pigments using supercritical carbon dioxide, J. Food Process Eng. 36 (2013) 3649.

[3] A. Martín, M.J. Cocero, Micronization processes with supercritical fluids: Fundamentals and mechanisms, Adv. Drug Deliv. Rev. 60 (2008) 339-350.

[4] A. Visentin, S. Rodríguez-Rojo, A. Navarrete, D. Maestri, M.J. Cocero, Precipitation and encapsulation of rosemary antioxidants by supercritical antisolvent process, J. Food Eng. 109 (2012) 9-15.

[5] A.S.M. Ghanem, H.S. Mohamed Ali, S. Mostafa El-Shanawany, E.S. Ali Ibrahim, Solubility and dissolution enhancement of quercetin Via preparation of spray dried microstructured solid dispersions, Thai J. Pharm. Sci. 37 (2013) 12- 
24.

[6] M. Kakran, N.G. Sahoo, L. Li, Dissolution enhancement of quercetin through nanofabrication, complexation, and solid dispersion, Colloids Surfaces B Biointerfaces. 88 (2011) 121-130.

[7] T. Pralhad, K. Rajendrakumar, Study of freeze-dried quercetin-cyclodextrin binary systems by DSC, FT-IR, X-ray diffraction and SEM analysis, J. Pharm. Biomed. Anal. (2004).

[8] Y. Zheng, I.S. Haworth, Z. Zuo, M.S.S. Chow, A.H.L. Chow, Physicochemical and structural characterization of quercetin-beta-cyclodextrin complexes, J. Pharm. Sci. 95 (2005) 1079-1089.

[9] C. Jullian, L. Moyano, C. Yañez, C. Olea-Azar, Complexation of quercetin with three kinds of cyclodextrins: An antioxidant study, Spectrochim. Acta - Part A Mol. Biomol. Spectrosc. 67 (2007) 230-234.

[10] T.H. Wu, F.L. Yen, L.T. Lin, T.R. Tsai, C.C. Lin, T.M. Cham, Preparation, physicochemical characterization, and antioxidant effects of quercetin nanoparticles, Int. J. Pharm. (2008).

[11] H.L. Li, X. Bin Zhao, Y.K. Ma, G.X. Zhai, L.B. Li, H.X. Lou, Enhancement of gastrointestinal absorption of quercetin by solid lipid nanoparticles, J. Control. Release. 133 (2009) 238-244.

[12] R.T. Buratto, E.G. Hoyos, M.J. Cocero, Á. Martín, Impregnation of açaí residue extracts in silica-aerogel, J. Supercrit. Fluids. 146 (2019) 120-127.

[13] M. Fraile, R. Buratto, B. Gómez, Á. Martín, M.J. Cocero, Enhanced delivery of quercetin by encapsulation in poloxamers by supercritical antisolvent process, Ind. Eng. Chem. Res. 53 (2014) 4318-4327.

[14] V.L. Singleton, R. Orthofer, R.M. Lamuela-Raventós, Analysis of total phenols and other oxidation substrates and antioxidants by means of folin-ciocalteu reagent, Methods Enzymol. 299 (1999) 152-178.

[15] AOAC Official Method, Total Monomeric Anthocyanin Pigment Content of Fruit Juices, Beverages, Natural Colorants, and Wines, in: AOAC Int. 37.1.68, 2005 .

[16] B. Ou, M. Hampsch-Woodill, R.L. Prior, Development and validation of an improved oxygen radical absorbance capacity assay using fluorescein as the fluorescent probe, J. Agric. Food Chem. 49 (2001) 4619-4626.

[17] F. Ganske, B.M.G. Labtech, ORAC Assay on the FLUOstar OPTIMA to 
Chapter 4

Determine Antioxidant Capacity, (2006). 

This research is a contribution to reduce the excessive amount of waste generated by the acai berry industry, promoting an effort for the valorization of the different byproducts generated by this industry (seeds, slurry and non-edible pulp), studying its viability as biomass and phytochemicals sources as well as its application in secondary formulations, such as cosmetics. This research complements previously available research, which only considered the characterization of the fresh fruit and not of the byproducts generated during the industrial processing.

At 'The final conclusions' chapter aims to present an overview of the objectives defined in this project, as well as to discuss the most important points achieved in each chapter previously presented, concluding the discussion with the subsequent works that will allow a deeper knowledge of the questions presented throughout this thesis.

The residues of E. Oleracea, obtained from industry (pulp - not suitable for human consumption -, seeds, and slurry), were characterized as biomass and potential phytochemical source in Chapter 1. The determination of the content of lipid, extractives, structural sugars, ashes, protein, and the phytochemical composition of each residual fraction was carried out applying the same methodology. The highest oil content was found at pulp fraction, with contents up to $43 \%$ on dry mass; the other fractions had a much lower oil content: seeds $3.5 \%$, and slurry $1.2 \%$. In the pulp oil a significant content of important fatty acids, such as oleic acid (58.5\%), linoleic acid (22.3\%), palmitic acid $(11.4 \%)$, and stearic acid (4.1\%) was identified. Pulp and seeds presented considerable values of water-soluble extractives, $23 \%$, and $13 \%$, respectively; while slurry just $3.4 \%$. All fractions showed good antioxidant capacity: seeds $65263 \mu \mathrm{mol}$ TE/100g $\mathrm{g}_{\mathrm{DM}}$, pulp $89760 \mu \mathrm{mol} \mathrm{TE} / 100 \mathrm{~g}_{\mathrm{DM}}$, and slurry $7870 \mu \mathrm{mol} \mathrm{TE} / 100 \mathrm{~g}_{\mathrm{DM}}$. Cellulose, hemicellulose, and lignin are the main components of the slurry fraction, with contents of $18 \%, 20 \%$, and, $36 \%$, respectively. On seeds, the main component found was hemicellulose, containing up to $48 \%$. As future work, it should be necessary to perform a deep study of using the slurry and seeds by-products as a biomass source.

In Chapter 2, a comparative study of extraction techniques was carried out using maceration as traditional extraction method, and microwave energy and microwave energy combined with pressurization as intensification technique. The study showed that temperature and removing the oil content before the extraction process were the most 
important paramenters in the extraction. As future work, it is proposed to perform a new study to evaluated other intensification technique, such as tip-ultrasound.

Once the extract were obtained, the protection of active ingredients from involuntary degradation, which would reduce the antioxidant activity of the extract, was analyzed. The formulation was successfully studied in chapter 3 and 4 . At Chapter 3, the impregnation of extracts in silica aerogels by a direct and indirect method was evaluated. Supercritical CO2-drying technology was applied as drying technique, and sol-gel process was used in the production of aerogels. The results showed for oil extract a maximum wt $\%$ of $58.6 \%$ when indirect impregnation and air drying were applied, and it decreased to $15 \%$ using SC drying, which indicates the extraction of components during SC drying. The maximum impregnation yield for polyphenolic extract was achieved with indirect impregnation and SC drying method, reaching a value of $16.4 \%$. Increasing the concentration of extract did not produce a higher impregnation yield.

At Chapter 4, the encapsulation of seeds and pulp extract in a polymeric matrix by Supercritical anti-solvent (SAS) process has been studied, and PVP was successfully applied as carrier agent in the co-precipitation. The experiments in which the extract obtained using the seeds as source and PVP as carrier material yielded viable results for the proportions $(1: 1),(2: 1)$, and (1:2). It was also proved to perform the processing of the pulp extract with PVP in different proportions. The pulp extract was processed by SAS with PVP in different proportions, the resulting materials showed no significant differences between each other by mean of TG analysis. During the study of seed extract formulation, it was determined the importance of the solid/liquid ratio on particle formation. This parameter not only affects the distribution of the co-precipitate but also implies the particle size. As future work, the efficiency of the formulated materials should be studied in an independent application, focusing on its antioxidants release, absorbance capacity and specific analysis, such as degradation tests, cell culture tests for their cosmetic application. Important future work is the study of efficiency of formulated material in secondary application, its behavior of antioxidant release and absorbance capacity, and other important tests such as release tests, degradation tests, and cell culture tests for cosmetic application. 
Resumen 


\section{Introduction}

Açaí es el nombre popular de Euterpe oleracea Mart. La fruta es originaria de la selva amazónica, y el interés de la industria se centra en su pulpa. Esta pulpa obtenida de açaí se comercializa como pulpa congelada, pura o mezclada con otros extractos de frutas. El açaí rara vez se consume como fruta fresca, lo que requiere un proceso industrial donde la pulpa se extrae, se filtra y se congela antes de su comercialización. La pulpa es alrededor del 16\% de la fruta entera, por lo que su procesado genera una gran cantidad de residuos que se compone de semillas, fibras y piel, lo que implica un gran problema ambiental. La pulpa muchas veces se convierte en parte del residuo pues es susceptible a muchas enfermedades, tales como la enfermedad de chagas. La pulpa se ha utilizado como tratamiento y prevención de algunas enfermedades, como la demencia, el Alzheimer, el Parkinson, la aterosclerosis, la obesidad y la gastritis, porque el extracto de açaí contiene agentes antioxidantes y antiinflamatorios. Los beneficios del extracto de $E$. Oleracea están asociados con la presencia de polifenoles, metabolitos secundarios de las plantas, especialmente relacionados con los flavonoides (un tipo de polifenoles), que incluyen voluteína, luteolina, apigenina y orientina, presentes en el extracto.

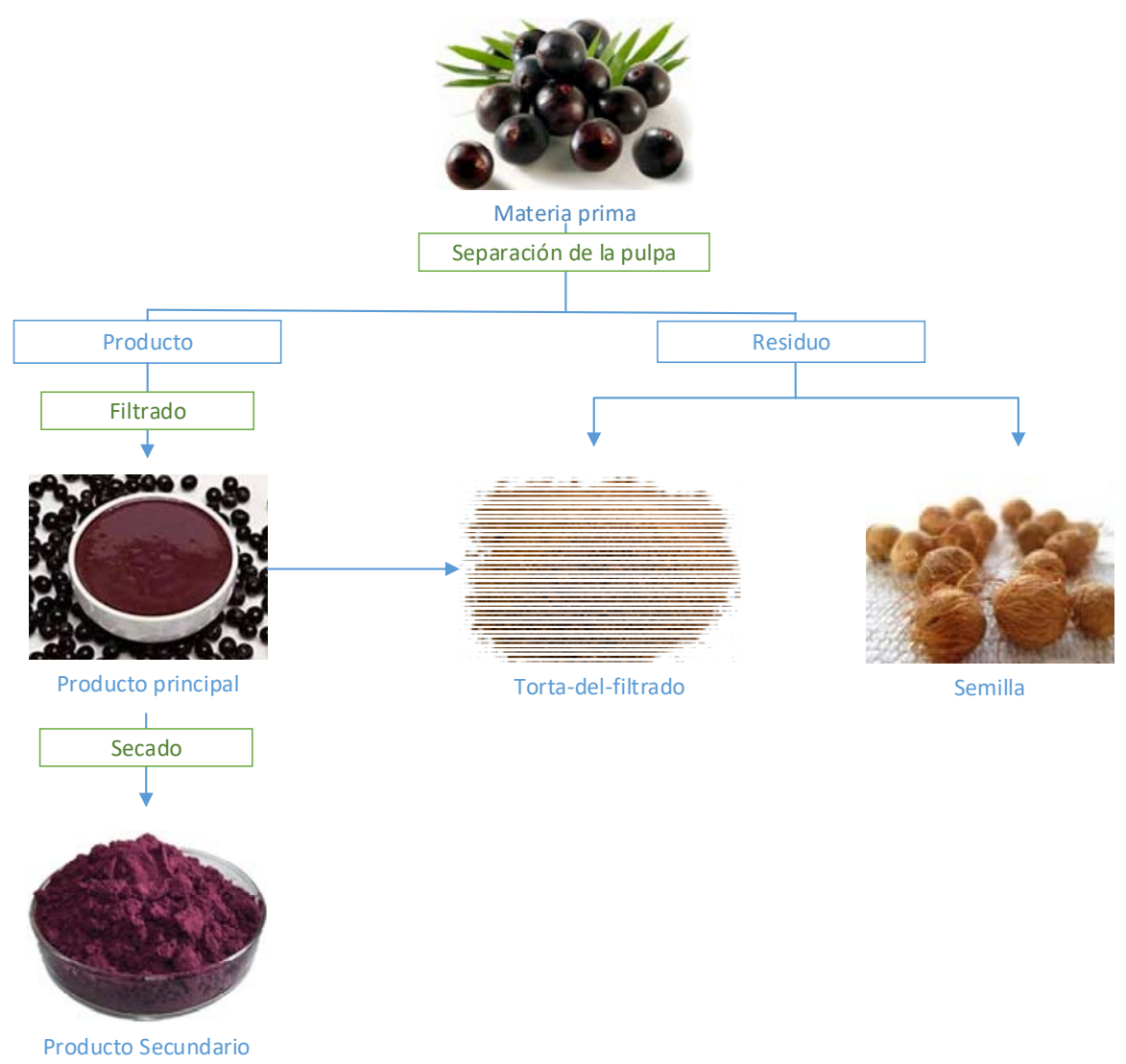

Figura 1 - Esquema de la industria procesadora de Açaí 


\section{Objetivo}

Esta tesis tiene por objetivo estudiar la valorización de los productos no comestibles de Euterpe Oleracea Mart producidos como subproductos del procesamiento industrial de esta fruta. Este estudio se concretó en los siguientes objetivos específicos:

(I) Caracterizar los subproductos obtenidos en el procesado de E. Oleracea, (pulpa - no útil para el consumo, semillas y torta-del-filtrado) como biomasa y fuente de gran potencial de fitoquímicos. Se determinará el contenido de lípidos, extractivos (polifenoles, antocianinas totales, contenido de flavonoides y taninos, y su actividad antioxidante mediante su valor ORAC), composición de la biomasa lignocelulosica (celulosa, hemicelulosa y lignina), cenizas, minerales fijos, proteínas y la composición fitoquímica de cada fracción residual aplicando la misma metodología.

(II) Estudiar la extracción de compuestos bioactivos por el método tradicional Soxhlet y la maceración. Además, se estudiará la intensificación del proceso aplicando calentamiento por microondas, y calentamiento por microondas combinado con presurización. Evaluar los beneficios del tratamiento en la cinética de extracción, así como las diferencias en términos de rendimiento de extracción, contenido total de polifenoles (TPC), contenido total de antocianinas (TAC) y actividad antioxidante mediante la capacidad de absorción de radicales de oxígeno (ORAC).

(III) Formular el material obtenido en la extracción de cada fracción del subproducto de E. Oleracea (torta-del-filtrado, semilla y pulpa) para su aplicación en productos como cremas y colorantes alimentarios naturales. Además, la formulación tenía como objetivo proteger los ingredientes activos de la degradación, lo que reduciría la actividad antioxidante del extracto. Específicamente se evaluarán dos tecnologías:

La impregnación de extractos en aerogeles de sílice por un método directo e indirecto, y aplicando tecnología de secado de $\mathrm{CO}_{2}$ supercrítico en la producción de aerogeles.

La encapsulación del extracto de semilla y de pulpa en una matriz polimérica mediante un proceso de precipitación con un fluido supercrítico como antidisolvente (SAS). 
Los objetivos de esta tesis se desarrollan en 4 capítulos, que se presentan a continuación:

* El Capítulo 1 presenta la caracterización de Euterpe Oleracea Mart. Pulpa (Açaí) y sus subproductos, determinando los extractos (según su contenido total de polifenoles, antocianinas, flavonoides y taninos, y actividad antioxidante mediante el valor del ORAC), y su contenido de celulosa, hemicelulosa y lignina.

* El Capítulo 2 presenta la extracción de polifenoles de los subproductos no comestibles de Euterpe Oleracea Mart. (açaí) como son las semillas, torta del filtrado, y la pulpa no apta al consumo, mediante un proceso de maceración, aplicando MAE y PMAE para intensificar el proceso de extracción, y mejorar la valorización de los subproductos del procesado de E. Oleracea.

* El Capítulo 3 presenta la formulación de extractos obtenidos mediante su impregnación en aerogeles de sílice.

* El Capítulo 4 presenta la formulación de los extractos obtenidos en un polímero, utilizando dióxido de carbono en condiciones supercríticas como antidisolvente.

\section{Resultados y discusión}

\subsection{Captulo 1 - Caracterización de Euterpe Oleracea Mart. (Açaí) Pulpa y sus fracciones} residuales: extractos y composición celulosa, hemicelulosa y lignina.

\subsubsection{Caracterización de biomasa}

La caracterización del residuo de E. Oleracea industrial se presenta en la tabla 1, en base de masa seca.

Tabla 1- Valores de caracterización (\% de masa seca)

\begin{tabular}{|c|c|c|c|c|c|c|c|c|c|}
\hline & Humedad & \multicolumn{3}{|c|}{ Extractivos } & \multicolumn{3}{c|}{ Carbohidratos estructurales } & Proteínas & Cenizas \\
\hline Fración & & Aceite & $\begin{array}{c}\text { Fase } \\
\text { acuosa }\end{array}$ & $\begin{array}{c}\text { Fase } \\
\text { etanolica. }\end{array}$ & Cellulosa & Hemicellulosa & Lignina & & \\
\hline Pulpa seca & 1,8 & $43,1 \pm 0,05$ & $23,6 \pm 5,65$ & $1,4 \pm 0,40$ & $5,9 \pm 0,15$ & $4,3 \pm 0,03$ & $9,2 \pm 1,54$ & $7,6 \pm 0,34$ & 1,03 \\
\hline Semillas & 8,5 & $3,5 \pm 0,08$ & $13,1 \pm 4,03$ & $0,9 \pm 0,63$ & $8,5 \pm 0,10$ & $48,1 \pm 0,45$ & $16,4 \pm 1,70$ & $9,3 \pm 1,52$ & 0,96 \\
\hline $\begin{array}{c}\text { Torta-del- } \\
\text { filtrado }\end{array}$ & 8,2 & $1,2 \pm 0,21$ & $3,4 \pm 0,03$ & $0,3 \pm 0,22$ & $18,6 \pm 0,16$ & $20,7 \pm 0,27$ & $36,2 \pm 1,00$ & $5,8 \pm 0,88$ & 0,67 \\
\hline
\end{tabular}


Los extractos representan un total de $68.1 \%, 17.5 \%$ y $4.9 \%$ en la pulpa, las semillas y la torta-del-filtrado, respectivamente. La pulpa es la fracción más abundante en extractivos, con un contenido de aceite del 43,1\%, en el que el 23,6\% son extractos acuosos, el 3,4\% son extractos en etanol y los compuestos restantes son extractos de hexano. El extracto de aceite no es muy representativo en las fracciones semillas y tortadel-filtrado, constituyendo $3.5 \%$ y $1.2 \%$, respectivamente. Sin embargo, debe eliminarse para evitar cualquier interferencia porque se observó que el aceite perturba el proceso de hidrólisis de la pulpa. Las semillas son una buena fuente de extractos, y el extracto acuoso obtenido también mostró excelentes características como fuente de compuestos antioxidantes. La torta-del-filtrado es la fracción más pobre en términos de cantidad de extractivos. Esto se esperaba porque la torta-del-filtrado está constituida por todos los fragmentos no deseados (como las fibras), que resultan del filtrado. En la industria, cuando se recupera esta fracción, tiene un color púrpura, dado por las antocianinas presentes en la pulpa, pero se degrada con el tiempo, finalmente aparece un tono marrón. El análisis de composición demostró que las semillas de açaí son ricas en hemicelulosas, que representa alrededor del $48 \%$ de la masa total. La torta-del-filtrado presentó un 18,6\% de celulosa, un $20,7 \%$ de hemicelulosa y una gran cantidad de lignina del $36,2 \%$.

\subsubsection{Aceite}

El aceite de pulpa de Açaí está compuesto por triglicéridos de cadena larga, los componentes principales son palmitodioleína (16:0-18:1-18:1) (26.97\%) y trioleína (18:1-18:1-18:1) (17,18\%), como se presenta en la Tabla 2, donde el perfil de triglicéridos presente en el aceite de la pulpa se presenta en base a la fracción de aceite total. El aceite está compuesto básicamente de oleico (18:1) (58.5\%), linoleico (18:2) (22.3\%), palmítico (16:0) (11.4\%), esteárico (18:0) (4.1\%), y ácidos palmitoleico (16:1) (3,7\%). El aceite obtenido de açaí puede considerarse un producto de interés para aplicaciones nutracéuticas debido a su alta concentración de ácidos oleicos (omega-9), la presencia de ácidos grasos esenciales como el ácido linoleico que no son producidos naturalmente por el metabolismo humano, y la fuerte presencia de otros ácidos de cadena insaturada. Estos tipos de ácidos grasos insaturados son beneficiosos para la salud humana porque ayudan a prevenir enfermedades como la diabetes y la presión arterial alta al reducir los niveles de triglicéridos y de colesterol en la sangre (LDL). La relación entre ácidos grasos 
insaturados y saturados se puede utilizar como parámetro de calidad. En este caso, el aceite de pulpa tiene una tasa de $2 / 3$.

Tabla 2 - Triglyceridos en el aceite de la pulpa de açaí.

\begin{tabular}{ccc} 
& \multicolumn{3}{c}{ Aceite de la Polpa } \\
Triglycerido & promedio (\%) & sd \\
\hline POO & 26,97 & 0,2 \\
OOO & 17,18 & 0,36 \\
POL+PoOL & 12,57 & 0,14 \\
POP & 11,76 & 0,16 \\
PLP+PPoO & 6,68 & 0,28 \\
OOL & 5,63 & 0,14 \\
EOL & 3,9 & 0,12 \\
PLE & 3,48 & 0,37 \\
PLL & 3,14 & 0,16 \\
EOO & 2,26 & 0,14 \\
PLPO+PoPoO & 1,37 & 0,12 \\
POE & 1,73 & 0,03 \\
OLL & 1,63 & 0,42 \\
ELL & 1,19 & 0,03 \\
ELE & 0,26 & 0,05 \\
EOE & 0,25 & 0,03 \\
\hline P: palmítico, 16:0; Po: palmitoleico, 16:1; E: esteárico, 18:0; O: oleico, 18:1; L: linoleico, $18: 2$.
\end{tabular}

\subsubsection{Extractos acuosos y etanólicos}

El extracto acuoso obtenido por Soxhlet está compuesto de azúcares, compuestos de nitrógeno, minerales, entre otros compuestos solubles en agua como las antocianinas y algunos polifenoles. En el extracto acuoso, la pulpa tiene un $23.1 \%$ de extractos en masa seca, las semillas $13.1 \%$ y la torta-del-filtrado $3.4 \%$. Los extractos etanólicos no estuvieron presentes en cantidades significativas, lo que puede deberse a la extracción previa. Ambos extractos, etanólicos y acuosos, se analizaron de acuerdo con su contenido total de antocianinas (TAC), polifenoles (TPC), flavonoides (TFC) y taninos (TTC). Los extractos también se clasificaron según su actividad antioxidante según la capacidad antioxidante de los radicales de oxígeno (ORAC). El ORAC para los compuestos antioxidantes solubles en agua encontrados para la pulpa y la torta-delfiltrado fueron 89760 y $7870 \mu \mathrm{mol}$ TE/100gDM, respectivamente. Los valores de ORAC encontrados son similares a los proporcionados por la base de datos ORAC del 'U.S. Department of Agriculture'. Para pulpa y piel: $99700 \mu \mathrm{mol}$ TE/100gDM. Es necesario sumar estos valores de ORAC obtenidos en la fase hidrofílica para fracciones de pulpa y pulpa para una mejor comparación, $97630 \mu \mathrm{mol}$ TE/100gDM. Esta capacidad antioxidante en la fase soluble en agua es similar a la observada en la misma porción de especias de salvia $(98714 \mu \mathrm{mol} \mathrm{TE} / 100 \mathrm{gDM})$, treinta veces mayor que la baya de Goji (3170 $\mu \mathrm{mol} \mathrm{TE} / 1100 \mathrm{gDM})$ y sesenta veces mayor que la uva roja (1640 $\mu \mathrm{mol} \mathrm{TE} /$ 
$100 \mathrm{gDM})$. Los extractos de semillas tenían $65263 \mu \mathrm{mol}$ TE / $100 \mathrm{gDM}$ de actividad antioxidante similar a la capacidad antioxidante de la pulpa [1]. Las antocianinas se identificaron en la fracción de pulpa para una concentración de 293,29 mg / 100 g de material seco, que es próximo al valor encontrado por Iaderoza (1992) 336 mg / 100 gDM y Schauss (2006) 319,19 mg / 100 g de DM de material seco [2][3]. No se observó la presencia de antocianinas en la fracción de la torta-del-filtrado, como se esperaba, ya que este compuesto puede degradarse fácilmente como resultado de unas malas condiciones de almacenamiento en la industria y durante el transporte.

\subsection{Capítulo 2 - Extracción de polifenoles de Euterpe Oleracea Mart. (açaí) Residuos}

La extracción con agua (con y sin microondas) del residuo de la torta-delfiltrado, se ha estudiado a dos temperaturas, $40^{\circ}$ y $60^{\circ} \mathrm{C}$. Se obtienen rendimientos de entre $0,12 \%$ y entre $0,06 \%$, con tiempos de extracción de 5 minutos. El rendimiento aumentó al aumentar la temperatura y con el empleo de calentamiento por microondas. Sin embargo, el rendimiento de extracción no fue alto con respecto a los otros disolventes utilizados, se debe a la presencia de aceite en la muestra, que crea una limitación para que penetre el agua en la matriz, de todos modos, la torta-del-filtrado (compuesta por pieles y fibras del paso de filtrado) no es una fracción rica en extractivos. El agua no es un solvente adecuado para la extracción de la pasta de açaí debido a su elevado contenido en aceite. El tiempo para lograr el máximo rendimiento de extracción (MEY) se redujo mediante la aplicación de MAE (extracción asistida por microondas). La temperatura es un parámetro importante en la extracción, incluso para el proceso de maceración sin pretratamiento cuando se incrementa la temperatura en $20^{\circ} \mathrm{C}$ el tiempo para lograr el MEY se reduce en 30 minutos. Se esperaba una mayor cantidad de polifenoles totales en la Torta-del-filtrado. El etanol /agua a $60^{\circ} \mathrm{C}$ dio los mejores resultados para la extracción de torta-del-filtrado, $0.614(\%)$ contra 4.428 (\%) del extracto del Soxhlet. El máximo rendimiento se logró usando MAE como pretratamiento. El etanol puro tiene potencial como solvente de extracción selectiva, 0.107 (\%) contra $0.188(\%)$ encontrado para el extracto de Soxhlet mediante etanol. No es posible identificar la mejor condición para la extracción con etanol, porque no fue posible observar una tendencia. La temperatura juega un papel esencial durante el proceso de extracción, e influye en la cantidad de fitoquímicos obtenidos y en su degradación. Las microondas ayudan al proceso de 
extracción promoviendo un rápido aumento de temperatura; La torta-del-filtrado tiene una exposición breve a la elevada temperatura, lo que disminuye la degradación. El extracto obtenido usando etanol/agua tiene un mejor potencial como antioxidante debido a la baja selectividad de solvente. Los resultados muestran que la temperatura de maceración también es importante para lograr un extracto con mejor poder antioxidante. El microondas tiene un efecto positivo cuando se aplicó etanol (50\%) y al etanol puro, sin embargo, este comportamiento no se observó en la extracción realizada con agua pura como solvente, debido al contenido de aceite presente en el material.

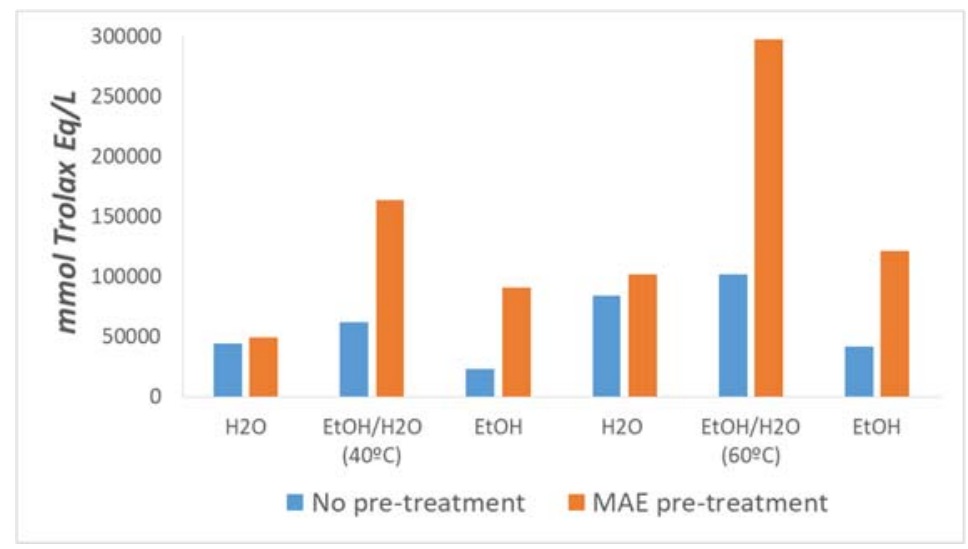

Figura 2 - Actividad antioxidante (ORAC) del contenido del extracto

\subsection{Capítulo 3 - Formulación por impregnación de Euterpe Oleracea Mart. (Açaí)} Extractos de residuos en sílice-aerogel

\subsubsection{Caracterización de los aerogeles.}

El aerogel de sílice puro es un material mesoporoso según su distribución de tamaño de poros. La curva de adsorción-desorción del $\mathrm{N}_{2}$ corresponde a una histéresis tipo IV e isoterma $H_{1}$, que se encuentra típicamente para materiales con poros muy estrechos, cilindros abiertos o cerrados, y tamaño y distribución uniformes.. Además, esta distribución es homogénea, presentando un valor promedio de $11 \mathrm{~nm}$. Los datos de poros suministrados se refieren a la isoterma de adsorción para evitar el efecto de bloqueo de poros que ocurrió durante la desorción de $\mathrm{N}_{2}$ debido a la condensación capilar que bloquea los poros e interfiere con la correcta determinación de los parámetros de textura. Sin embargo, el tipo de impregnación (directa o indirecta) y el método de secado pueden 
interferir en la estructura, así como en su área de superficie específica, volumen de poro promedio y diámetro de poro promedio, como se discute en las siguientes secciones.

\subsubsection{Impregnación húmeda:}

El tipo de impregnación (directa o indirecta) y el método de secado pueden interferir en la estructura, así como en su superficie específica, volumen de poro y diámetro de poro promedio. Estos datos se presentan en la Tabla 3.

Tabla 3 - Propiedades de los aerogeles impregnados con los extractos obtenidos de las diferentes fracciones de los subproductos del procesado del Açaí.

\begin{tabular}{ccccccc}
\hline Extract & Fraction & $\begin{array}{c}\text { Impregnation } \\
\text { process }\end{array}$ & $\begin{array}{c}\text { Dry } \\
\text { Process }\end{array}$ & $\begin{array}{c}\text { Specific } \\
\text { Surface area } \\
(\mathrm{m} 2 / \mathrm{g})\end{array}$ & $\begin{array}{c}\text { Average pore } \\
\text { volume } \\
(\mathrm{cm} 3 / \mathrm{g})\end{array}$ & $\begin{array}{c}\text { Average pore } \\
\text { diameter }(\mathrm{nm})\end{array}$ \\
\hline Blanco & & - & SC & 910 & 3.04 & 11.0 \\
Blanco & & - & Air & & & \\
Aceite & Polpa & Directo & SC & 892 & 2.98 & 13.4 \\
Aceite & Polpa & Indirecto & SC & 848 & 2.89 & 10.9 \\
Aceite & Polpa & Indirecto & SC & 823 & 2.78 & 11.0 \\
Aceite & Semilla & Indirecto & SC & 847 & 2.54 & 12.4 \\
Polyphenolico & Polpa & Directo & SC & - & - & - \\
Polifenólico & PolpaPolpa & Directo & Air & 595 & 0.04 & 0.3 \\
Polifenólico & Polpa & Indirecto & SC & 856 & 1.80 & 9.1 \\
Polifenólico & Polpa & Indirecto & air & 830 & 0.26 & 3.6 \\
Polifenólico & Polpa & Indirecto & SC & 873 & 1.60 & 8.2 \\
Polifenólico & Semilla & Indirecto & SC & 739 & 2.43 & 10.0 \\
\hline Directo
\end{tabular}

Directo $=$ impregnación húmeda por método directo; Indirecta $=$ impregnación húmeda por método indirecto.

\subsubsection{Impregnación húmeda:}

Los monolitos formados se dividieron en dos grupos para evaluar los efectos del método de secado sobre la estructura del aerogel y los compuestos adsorbidos. El secado al aire ha provocado el colapso de los poros y, como resultado, los monolitos son mucho más pequeños que los moldes (Fig. 3 (A-II). En cambio, los monolitos secados con $\mathrm{CO}_{2}$ supercrítico mantuvieron la forma y el tamaño del patrón (Fig. 3 (AI)). El primer parámetro para determinar cómo se ha producido la impregnación es el análisis visual. Tomando la intensidad del color como parámetro es posible determinar que la impregnación indirecta (Fig. 3 (C-I y C-II)) funcionó mejor que la impregnación directa (Fig. 2 (B-I y B-II). Además, el diámetro de poro de los geles obtenidos del secado SC $\mathrm{CO}_{2}$ (tabla 3) e impregnación directa $(13.4 \mathrm{~nm})$ son mayores que los geles impregnados con el método indirecto $(10.9 \mathrm{~nm})$. Esto se debe a que la adición directa de extracto en aerogeles aumentó el tiempo de gelificación que interviene en la formación de poros. 
Además, se observó que, usando este método, los monolitos liberaron lentamente el aceite impregnado, durante los procesos de maduración. En relación con la eficiencia del proceso de secado, se observó una diferencia significativa en la intensidad del color entre las muestras obtenidas del secado $\mathrm{SC} \mathrm{CO}_{2}$ (Fig. 3 (BI \& CI)) y el secado al aire natural (Fig. 3 (B-II \& C-II)). Una posible razón para este hecho es la extracción parcial del aceite por $\mathrm{SC} \mathrm{CO}_{2}$, siendo un inconveniente del proceso de secado $\mathrm{SC} \mathrm{CO}_{2}$.

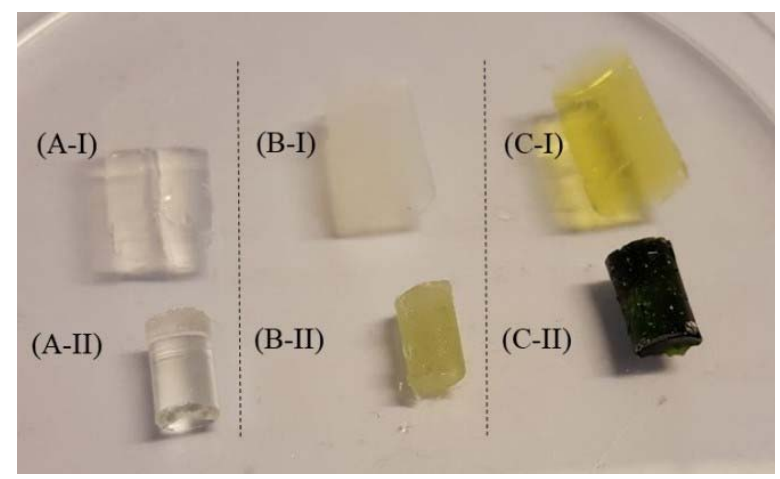

Figura 3 - Monolitos de gel de sílice impregnado con extracto de aceite de pulpa: (A) blanco, (B) proceso directo, y (C) proceso indirecto; secado por (I) $\mathrm{CO}_{2}$ supercrítico y

(II) aire.

\subsubsection{Impregnación húmeda: extracto polifenólico}

Las antocianinas presentes en el extracto polifenólico de la pulpa son responsables del color púrpura observado en los monolitos impregnados con este extracto. Por lo tanto, el color también puede funcionar como un parámetro para inferir si la impregnación ocurrió o no. De esta manera, es posible ver en la Fig. 3B la diferencia producida por la impregnación indirecta, tomando como comparación la Fig. 3A, y un blanco. Los resultados presentados en la Tabla 2 también muestran la diferencia en el tamaño de los poros, la diferencia entre el tamaño de los poros y el volumen de poros en el material en blanco, $11.0 \mathrm{~nm}$, y $3.1 \mathrm{~cm} 3 / \mathrm{g}$, y en el aerogel de sílice impregnado, $9.1 \mathrm{~nm}$ y $1.8 \mathrm{~cm} 3 / \mathrm{g}$. Estos resultados indican que los polifenoles están ocupando los poros más grandes, debido a un menor limitación en su acceso. El color fue más intenso en aquellos geles impregnados por impregnación directa (Fig. 4 (C-II)). En este caso específico, el color más fuerte está relacionado con la imposibilidad de realizar el proceso de envejecimiento una vez que de la impregnación directa que no permitió la gelificación de los monolitos, incluso después de varias horas. La razón está en que este lote simplemente se secó al aire y no se produjo el período de maduración. Como resultado, este lote cambió 
su tipo de porosidad, como lo indican los resultados en la Tabla 3, convirtiéndose en un material microporoso con un tamaño de poro de $0.3 \mathrm{~nm}$ y un volumen de poro de 0.04 $\mathrm{cm} 3$ / g. La forma obtenida también es inusual, debido al secado al aire que ocurre dentro del molde, y por lo tanto, la contracción de los monolitos resultantes del colapso de los poros ocurrió solo en la dirección horizontal.

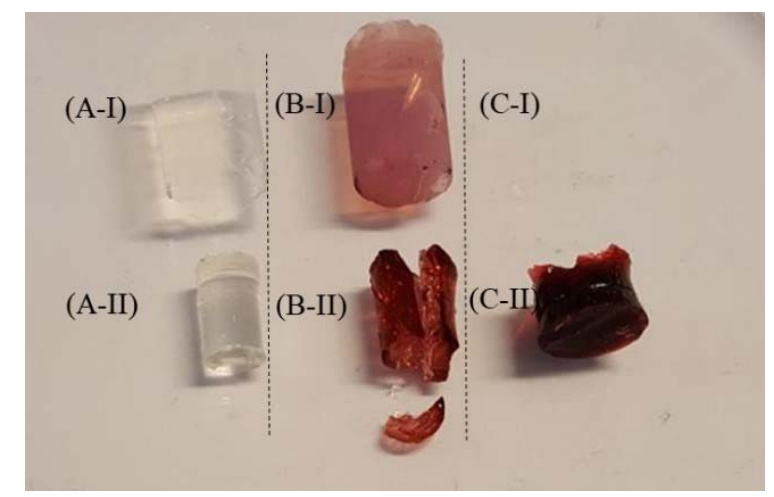

Fig. 4 - Monolitos secos de gel de sílice impregnado por extracto de la pulpa por etanol/agua: (A) blanco, (B) proceso directo y (C) proceso indirecto; secado por (I) $\mathrm{CO}_{2}$ supercrítico y (II) aire.

También es posible resaltar la modificación estructural producida por la impregnación y el proceso de secado del aerogel de sílice. (Fig. 5). La forma de las isotermas de adsorción de $\mathrm{N}_{2}$ se ve afectada por el tamaño y la geometría del material poroso. De esta manera, es posible clasificar el material de acuerdo con su isoterma. El material impregnado, obtenido mediante secado $\mathrm{SC} \mathrm{CO}_{2}$, muestra el mismo tipo de isoterma que se observó en sílice pura, $\mathrm{H}_{1}$. Sin embargo, su curva es más pronunciada, denotando un tamaño de poros más pequeño. Este resultado está relacionado con la ocupación de poros por los polifenoles.

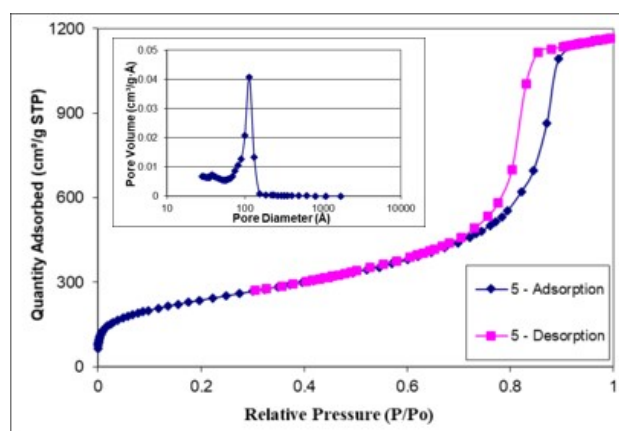

(I)

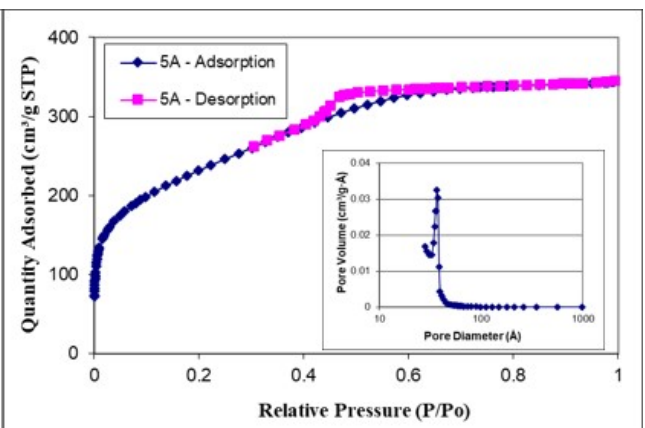

(II)

Fig. 5 - Distribución isotérmica y de volumen de poro del aerogel de sílice impregnado con pulpa polifenólica secada con (I) $\mathrm{CO}_{2}$ supercrítico y (II) aire. 


\subsubsection{Extracto de aceite}

La masa total impregnada se puede calcular como la diferencia entre la masa residual en una muestra impregnada y la masa restante en el blanco. Los resultados se presentan en la Tabla 4.

Tabla 4 - Rendimiento de impregnación y contenido total de polifenoles liberados.

\begin{tabular}{|c|c|c|c|c|}
\hline $\begin{array}{c}\text { Extracto } \\
\text { impregnado }\end{array}$ & $\begin{array}{c}\text { Metodo de } \\
\text { impregnación }\end{array}$ & Secado & $\mathrm{Wt} \%$ & $\begin{array}{c}\text { Plifenoles liberado } \\
(\mathrm{mg} \text { GAe/gaerogel })\end{array}$ \\
\hline \multirow{2}{*}{$\begin{array}{l}\text { Aceite de la } \\
\text { pulpa* }\end{array}$} & \multirow[t]{2}{*}{ Directo } & $\mathrm{SC}$ & 9.1 & 0.229 \\
\hline & & Aire & 13.5 & \multirow{3}{*}{0.120} \\
\hline \multirow{2}{*}{$\begin{array}{c}\text { Aceite de la } \\
\text { pulpa } * *\end{array}$} & \multirow[t]{2}{*}{ Indirecto } & $\mathrm{SC}$ & 12.9 & \\
\hline & & Aire & 37.5 & \\
\hline \multirow[t]{2}{*}{$\begin{array}{l}\text { Aceite de la } \\
\text { pulpa } * * *\end{array}$} & \multirow[t]{2}{*}{ indirecto } & $\mathrm{SC}$ & 15.3 & 0.317 \\
\hline & & Aire & 58.6 & 0.191 \\
\hline
\end{tabular}

Según los resultados de la tabla 3, la impregnación directa, que causó una gelificación lenta, condujo a un rendimiento de impregnación menor que la impregnación indirecta. Durante el ensayo de liberación, los aerogeles impregnados por el método directo liberaban una baja concentración de polifenoles, incluso cuando la concentración de aceite impregnado era más alta. Este resultado se atribuye a una baja gelificación de monolitos. Otro hecho que también contribuyó aquí fue que, durante el paso de maduración, el aceite fue liberado lentamente de los poros. Con el método de impregnación indirecta, un aumento de la concentración de aceite durante la impregnación produjo un rendimiento en la impregnación más alto. Esto está relacionado con la alta capacidad de sílice para absorber el aceite. Además, las muestras secadas por aire y por fluidos supercríticos muestran una gran diferencia en el rendimiento de impregnación. Esto puede ser debido al tipo de deposición de extracto de aceite dentro de los poros. Los polifenoles en el extracto de aceite tienen grupos hidroxilo que pueden realizar enlaces con la estructura de Si-O del aerogel, mientras que los aceites están unidos en grupos triglicéridos, que no pueden lograr un enlace similarmente con la matriz de aerogel. A pesar de la pérdida producida por el proceso de secado, al eliminar parte del contenido impregnado, el ensayo de liberación ha demostrado que la cantidad de polifenoles liberados fue proporcional a la concentración inicial y no se vio afectada por el secado SC. Según el análisis de TGA, el rendimiento máximo de impregnación, 58,6\%, 
se alcanzó cuando se aplicaron la impregnación indirecta y el secado al aire. En el mismo lote, los monolitos secados por secado SC tuvieron un rendimiento de impregnación de alrededor del 15\%. Por otro lado, el método de secado al aire afecta la estructura porosa, lo que provoca el colapso de los poros. La pérdida de compuestos solubles de $\mathrm{SC}-\mathrm{CO}_{2}$ en el rendimiento impregnado depende de la cantidad de $\mathrm{SC}-\mathrm{CO}_{2}$ utilizada en el proceso de secado; sin embargo, disminuir esta cantidad puede afectar la eficacia del secado y que quede alcohol residual en el aerogel. La relación se mantuvo constante a $0,0347 \mathrm{~kg}$ de $\mathrm{CO}_{2} / \mathrm{g}$ de aerogel seco por ciclo.

\subsubsection{Extracto de polifenoles}

De acuerdo con los datos de TGA presentados en la Tabla 5, el rendimiento máximo de impregnación fue de $16.4 \%$ alcanzado con el método de impregnación indirecta y secado SC. El aumento de la concentración de la solución inicial no afectó el rendimiento de impregnación, pero disminuyó las limitaciones de las sustancias bioactivas para ocupar los poros, lo que resultó en un cambio de color, como se observa en la Fig. 6. Además, el ensayo de liberación puede confirmarlo mediante el aumento de polifenoles. y antocianinas liberadas. Los datos publicados están relacionados con la cantidad absorbida. La mayor concentración en la disolución produce mayores cargas. Esto puede deberse a una mayor cantidad de soluto dentro de los poros en lugar de una mayor adsorción. Los monolitos obtenidos con impregnación directa no pudieron gelificarse adecuadamente y se secaron solo con aire y sin tiempo de maduración. Este proceso cambia la estructura del material, convirtiéndolo en un material microporoso. El rendimiento de impregnación no se vio afectado por este evento, pero sí afectó la capacidad de los aerogeles para liberar el contenido impregnado. La impregnación del aerogel de sílice mesoporoso permitió aumentar la termoestabilidad del extracto de $30^{\circ} \mathrm{C}$ a $270^{\circ} \mathrm{C}$, con el método indirecto. Se observó una termoestabilidad similar con ambos procesos de secado. Aunque se observó, que en un mismo lote, una ligera tendencia a valores más altos en aquellas muestras producidas por secado con fluido supercrítico, con una variación de $\pm 10^{\circ} \mathrm{C}$ en la temperatura de inicio. Sin embargo, el método de impregnación fue significativo, las muestras producidas con método directo presentan una termoestabilidad sustancialmente menor que las impregnadas con método indirecto: $270^{\circ} \mathrm{C}$ y $195^{\circ} \mathrm{C}$, respectivamente. Esto está relacionado con el agua presente en el proceso sol-gel. En este proceso, primero se produce un hidrogel, y durante el tiempo de maduración, los grupos agua-OH son reemplazados por los grupos alcohol-OH, 
convirtiéndose en alcohol-gel. Aquí, estas muestras, directamente impregnadas, no se habían gelificado adecuadamente, haciendo imposible el paso de maduración y la formación adecuada de un gel de alcohol. Esto puede afectar a la unión entre Si-O y polifenol, reduciendo la termoestabilidad.

Tabla 5 - Rendimiento de impregnación de extracto polifenólico y contenido total de polifenoles y antocianinas liberados.

\begin{tabular}{ccccccc}
\hline \multirow{2}{*}{$\begin{array}{c}\text { metodo de } \\
\text { impregnación }\end{array}$} & secado & $\begin{array}{c}\mathrm{Wt} \\
\%\end{array}$ & $\begin{array}{c}\text { Polyfenoles } \\
(\mathrm{mg} \mathrm{GAe} / \mathrm{L})\end{array}$ & $\begin{array}{c}\text { Antocyaninas } \\
(\mathrm{mg} \mathrm{AC} / \mathrm{L})\end{array}$ & $\begin{array}{c}\text { concentración de liberación } \\
\text { Polyfenoles } \\
\left(\mathrm{mg} \mathrm{GAe} / \mathrm{g}_{\text {Aeroge }}\right)\end{array}$ & $\begin{array}{c}\text { Antocyaninas } \\
\left(\mathrm{mg} \mathrm{AC} / \mathrm{g}_{\text {Aerogel }}\right)\end{array}$ \\
\cline { 6 - 7 } $\begin{array}{c}\text { directo } \\
\text { Indirecto }\end{array}$ & Aire & 11.0 & - & - & 0.708 & 0.034 \\
Indirecto & SC & 16.4 & 527.4 & 24.3 & 1.391 & 0.042 \\
\hline
\end{tabular}

$\mathrm{SC}=$ supercrítico; $\mathrm{GAe}=$ equivalente de ácido gálico; $\mathrm{AC}=$ contenido de antocianina

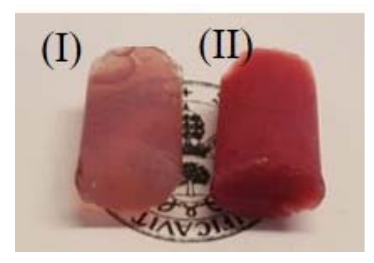

Fig. 6 -Monolitos secos de gel de sílice impregnado por extracto de pulpa por etanol / agua: (I) Baja concentración y (II) alta concentración.

3.4 Capitulo 4 - Coprecipitación de los extractos de pulpa y semilla de Açaí mediante tecnología Supercrítica Antidisolvente.

Se han realizado ensayos de precipitación en diferentes proporciones, solventes y encapsulantes. Los mejores resultados se observaron cuando se utilizó etanol como disolvente y PVP como agente encapsulante. Los ensayos realizados con acetona como disolvente produjeron una muestra con un aspecto plastificado; además, se observó precipitación en la solución inicial. También se determinó que el calentamiento moderado aplicado $\left(30^{\circ} \mathrm{C}\right)$ ayudó en la homogeneización de la solución de encapsulación. Se procesaron diferentes proporciones de extracto de semillas y PVP, comenzando en la proporción de 2:1,1:1,1:2, hasta un máximo de 1:4; Todos los materiales encapsulados tenían aspecto de polvo, sin embargo, en la proporción de 1: 4, el material resultante era irregular y peletizado. Esa proporción de extracto de semillas/PVP por encima de la tasa de 1: 4, resultó en material plastificado. El extracto de pulpa y PVP se procesaron con 
éxito en proporciones de 2: 1 y 1: 1. El intento de aumentar la proporción de PVP a 1:2, produjo un material plastificado. El Pluronic F127 no fue compatible con ningún extracto.

\subsubsection{Análisis químico del producto.}

El análisis del producto revela que el material obtenido de la formulación de los extractos de semillas presentó el contenido total de polifenoles que se corresponde con el contenido esperado según la concentración de extracto y encapsulante en la solución inicial. Sin embargo, aquellos materiales en los que se aplicó extracto de pulpa no presentaron contenido fenólico significativo además de la presencia del color típico producido por la presencia de antocianinas.

La Tabla 6 presenta el contenido fenólico total (en equivalente de ácido gálico) en el producto obtenido. El extracto puro procesado individualmente se toma como referencia para comparar la formación de partículas. El extracto único procesado por SAS se enriqueció según la muestra original, está relacionado con la selectividad de $\mathrm{CO}_{2}$, durante la precipitación no se precipita todo el contenido inicial, hay componentes en el extracto que mostraron afinidad por el $\mathrm{CO}_{2}$ (como el aceite residual) Sin embargo, los polifenoles en general serán muy pobres en $\mathrm{CO}_{2}$ y todos precipitarán. Por lo tanto, el material final son partículas enriquecidas en polifenoles con respecto al material inicial. Es posible observar que al realizar partículas en la misma proporción (1: 1), la proporción intermedia (masa/solvente) podría encapsular y preservar mejor el extracto. La misma tendencia se observó en otras proporciones $(2: 1)$ y (1:2). Sin embargo, las partículas formadas, usando Pluronic F127 como vehículo, se plastificaron, el producto pudo proteger el extracto que ha presentado buenos valores de TPC. Además, el material procesado individual presentó valores de polifenoles totales dos veces más alto que el material de partida.

Resultados similares a los obtenidos con el extracto de semillas de açaí, se obtuvieron el extracto de pulpa, también presentó mejores resultados cuando se aplicaron proporciones intermedias (masa / solvente). Aunque no fue posible recuperar el extracto procesado sin la adicción de polímero y por conseguinte realizar los análisis pertinentes del extracto de la pulpa procesado, fue posible comparar los resultados con la pulpa original y observar que el material procesado tiene una cantidad menor de TPC de lo esperado. También se realizaron pruebas para evaluar el contenido total de antocianinas totales por espectrofotometría. Ninguno de los materiales probados mostró contenido de 
antocianina detectable, aunque todos tienen una coloración rosa clara, típicamente producida por la presencia de esta sustancia.

Tabla 6 - Contenido total de polifenoles (TPC) en material procesado SAS.

\begin{tabular}{|c|c|c|c|c|c|}
\hline $\begin{array}{l}\text { Extracto } \\
\text { (fuente) }\end{array}$ & Polímero & Solvente & Ratio & $\begin{array}{l}\text { masa/solvente } \\
(\mathrm{g} / \mathrm{L})\end{array}$ & $\begin{array}{c}\mathrm{mg} \mathrm{GAE} / \mathrm{g} \\
\text { particula }\end{array}$ \\
\hline $\begin{array}{c}\text { semilla } \\
\text { (no } \\
\text { procesada) }\end{array}$ & - & - & - & 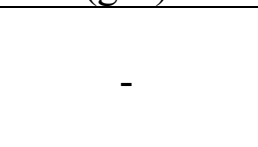 & 261 \\
\hline semilla & - & Etanol & - & 3.33 & 500 \\
\hline semilla & PVP & Etanol & $1 ; 1$ & 5.00 & 78 \\
\hline semilla & PVP & Etanol & $1 ; 1$ & 3.33 & 211 \\
\hline semilla & PVP & Etanol & $1 ; 1$ & 2.50 & 80 \\
\hline semilla & Pluronic & Acetona & $1 ; 1$ & 3.33 & 132 \\
\hline semilla & PVP & Etanol & $2 ; 1$ & 5.00 & 142 \\
\hline semilla & PVP & Etanol & $2 ; 1$ & 3.33 & 187 \\
\hline semilla & PVP & Etanol & $1 ; 2$ & 5.00 & 54 \\
\hline semilla & PVP & Etanol & $1 ; 2$ & 3.33 & 72 \\
\hline $\begin{array}{l}\text { Pulpa (no } \\
\text { procesada) }\end{array}$ & - & - & - & - & 108 \\
\hline Pulpa & - & Etanol & - & - & - \\
\hline Pulpa & PVP & Etanol & $2 ; 1$ & 3.33 & 7 \\
\hline Pulpa & PVP & Etanol & $1 ; 1$ & 5.00 & 27 \\
\hline Pulpa & PVP & Etanol & $1 ; 1$ & 3.33 & 31 \\
\hline Pulpa & PVP & Etanol & $1 ; 1$ & 2.50 & 35 \\
\hline
\end{tabular}

\subsubsection{Estudio morfológico}

El estudio de la morfología fue proporcionado por imágenes de microscopio electrónico de barrido (SEM). El proceso SAS ha permitido la formación de macropartículas conteniendo el extracto de semillas. Las imágenes SEM permiten observar las diferencias en la morfología de las partículas con extracto de semillas y con al polímero original. Además, cuando se aplicó PVP como polímero en el proceso de encapsulación, fue posible producir partículas aún más pequeñas (Tabla 7). El Pluronic F-127 no mostró buenas propiedades como agente encapsulaste, los resultados experimentales muestras que se obtiene un material plastificado.

Tabla 7- comparativa de imágenes SEM del PVP, del extracto de semillas y extractos de semillas encapsulado mediante el proceso SAS. 


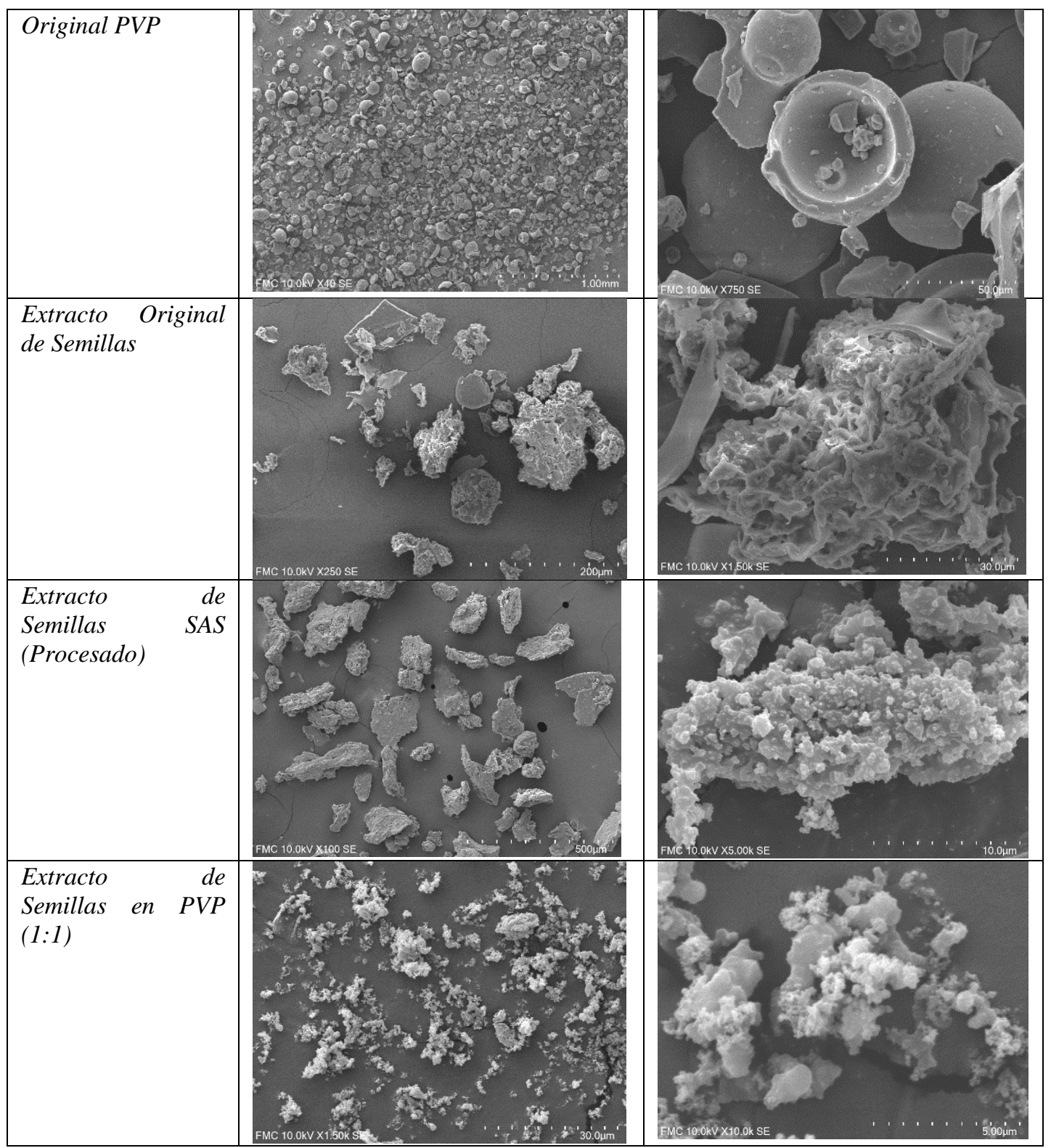

Como se observó para el análisis de TPC, la relación de solvatación es importante porque al aumentar la relación masa / disolvente aumenta la dificultad en la coprecipitación. La partículas de la Figura 7 presentan una buena coprecipitación, con áreas bien cubiertas; también es el producto en el que el valor de TPC fue mayor. 


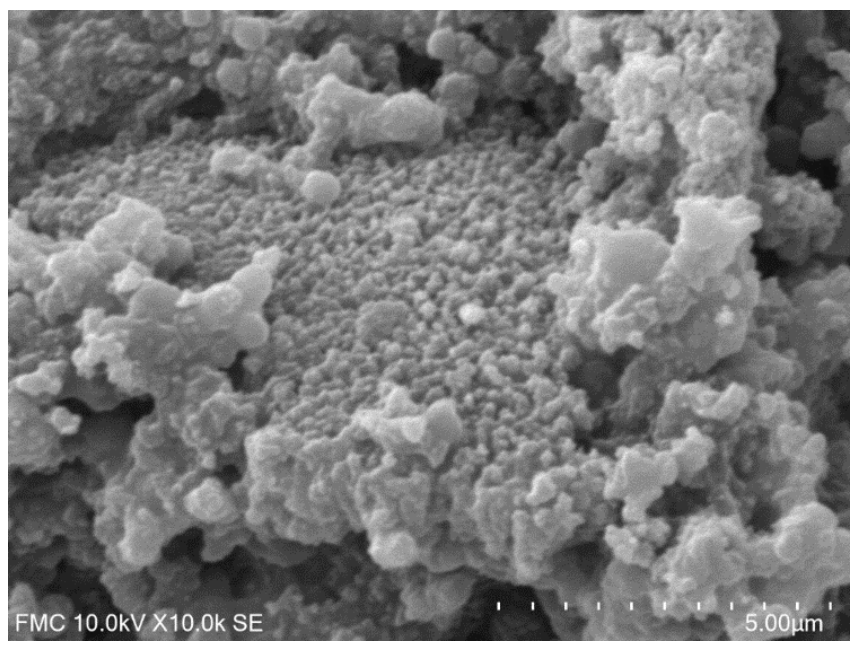

Figura 7 - Semillas-extracto coprecipitado con PVP a una relación (1:1), 3,33 g/L.

Sin embargo, la minimización excesiva de la relación masa / solvente causó un mal funcionamiento de la bomba, causando bloqueos, lo que impide el bombeo de flujo constante de la Torta-del-filtrado. El resultado se observa en la figura 8.

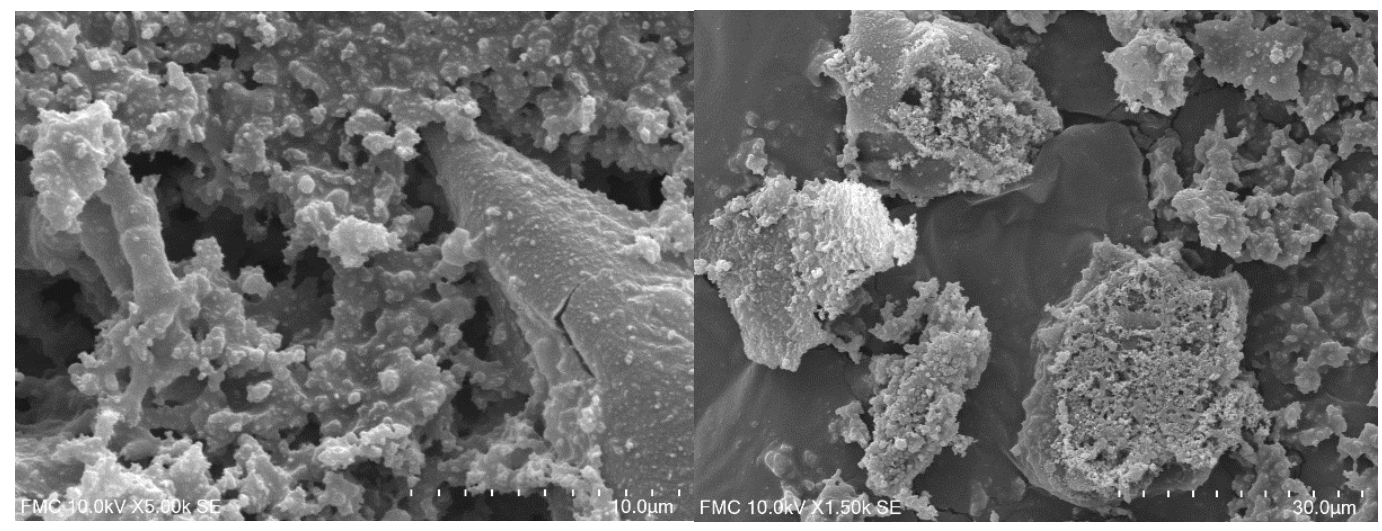

Figura 8 -Extracto de semillas coprecipitado con PVP a una relación (1: 1), 5 g / L.

La mejor concentración encontrada fue $2.5 \mathrm{~g} / \mathrm{L}$, a esta relación de solvatación fue posible obtener un material coprecipitado, áreas mejor distribuidas, menos expuestas y un tamaño de partícula pequeño. La relación de solvatación cambió el tamaño de partícula final. 


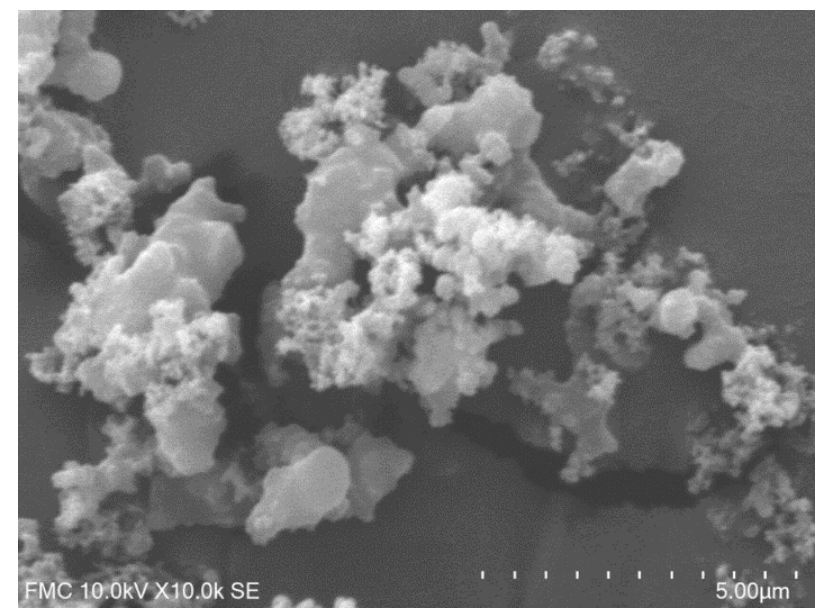

Figura 9 -Extracto de semillas coprecipitado con PVP a una relación (1: 1), $2.5 \mathrm{~g} / \mathrm{L}$.

Cuando el extracto de pulpa se procesó individualmente, sin polímero, no se obtuvieron partículas, se atribuyó a una fuerte micronización, donde la partícula no pudo ser retenida por el filtro $(0,45 \mu \mathrm{m})$. Las imágenes SEM (Figura 10) obtenidas a través del análisis del producto permitieron observar pequeños fragmentos de extracto insertados en el polímero. Es difícil saber si el material en cuestión está dentro de la masa del polímero o si se observó el mismo patrón que para la micronización y la pérdida de material. La pulpa de açaí es un material muy oleoso; El 43\% de su peso seco es contenido de aceite. se trató para eliminar el aceite en la pulpa antes de la extracción, pero tal vez haya un contenido restante que indujo tal diferencia entre ambos extractos (El de la semilla y el de la pulpa).

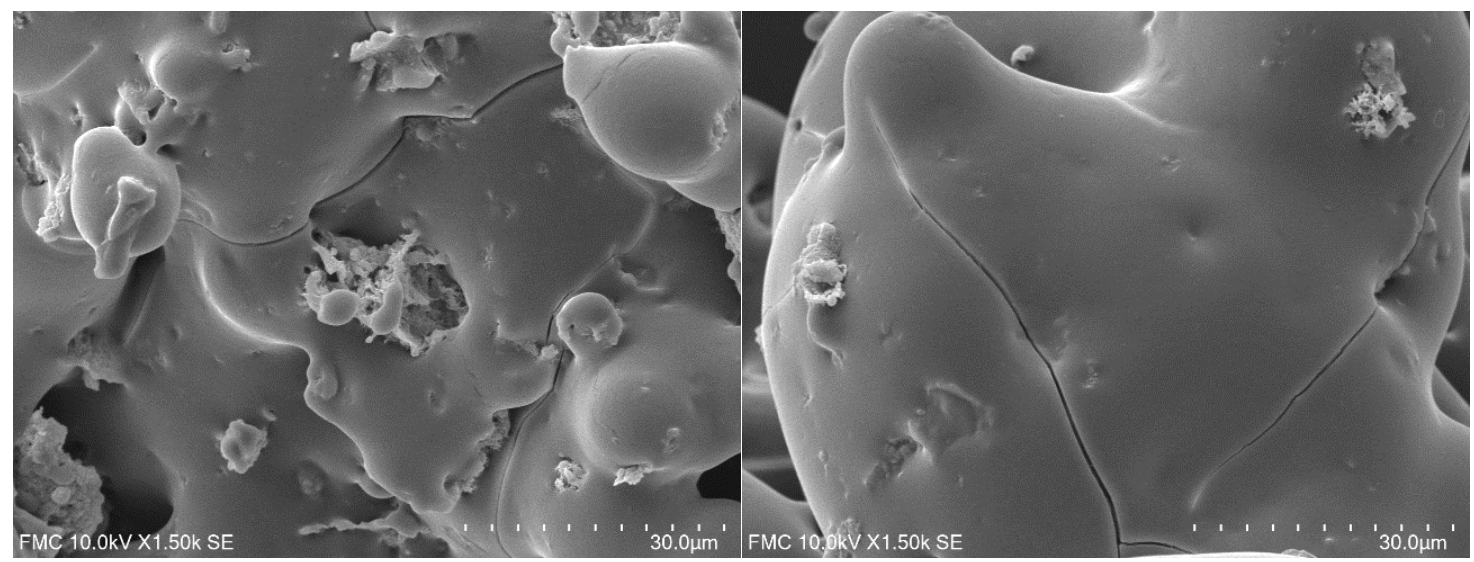

Figura 10 - Extraído de pulpa y PVP procesado a una relación (1:1): (a) 5.0g/L, y (b) 


\section{Conclusiones}

Esta investigación es una contribución para reducir la cantidad excesiva de residuos generados por la industria de acai, promoviendo un esfuerzo para la valorización de los diferentes subproductos generados por esta industria (semillas, torta-del-filtrado y pulpa no comestible). Se aporta su caracterización para poner de manifiesto su uso como biomasa lignocelulosica y fuente fitoquímicas. Se han desarrollado productos mediante formulación de los compuestos activos para su aplicación en formulaciones para usos cosméticos. Esta investigación aporta contribuciones relevantes sobre los estudios previos, que solo consideraba la caracterización de la fruta fresca y no de los subproductos generados durante el procesamiento industrial. En este capítulo de conclusiones se pretende presentar una visión general de los objetivos definidos en este proyecto, así como discutir los puntos más importantes alcanzados en cada capítulo presentado anteriormente, concluyendo la discusión con los trabajos posteriores que permitirán un conocimiento más profundo de las cuestiones que han quedado abiertas en este estudio.

Los residuos de E. Oleracea, obtenidos de la industria (pulpa, no apta para el consumo humano, semillas y lodos), se caracterizaron como biomasa y fuente de compuestos fitoquímicos. En el capítulo 1 se presenta la determinación del contenido de lípidos, extractos, y hemicelulosas, celulosa y lignina. La composición en los principales compuestos fitoquímicos de cada fracción, el contenido en proteínas y cenizas. El mayor contenido de aceite se encontró en la fracción de pulpa, con contenidos de hasta $43 \%$ en masa seca; las otras fracciones tenían un contenido de aceite mucho más bajo: semillas $3.5 \%$ y torta-del-filtradotorta-del-filtrado $1.2 \%$. En el aceite de pulpa se identificó una fuerte presencia de ácidos grasos importantes como el ácido oleico (58.5\%), ácido linoleico (22.3\%), ácido palmítico (11.4\%) y ácido esteárico (4.1\%). La pulpa y las semillas presentaron valores considerables de extractos solubles en agua, 23\% y 13\%, respectivamente; mientras que la torta-del-filtrado solo 3.4\%. Todas las fracciones mostraron una buena capacidad antioxidante: semillas $65263 \mu \mathrm{mol}$ TE / 100gDM, pulpa $89760 \mu \mathrm{mol}$ TE / 100gDM y Torta-del-filtrado $7870 \mu \mathrm{mol}$ TE / 100gDM. La celulosa, la hemicelulosa y la lignina son los componentes principales de la fracción de Torta-delfiltrado, con contenidos del 18\%, 20\% y 36\%, respectivamente. En las semillas, el componente principal encontrado fue la hemicelulosa, que contiene hasta un $48 \%$. Como trabajo futuro se propone estudiar las aplicaciones de la Torta-del-filtrado y las semillas como fuente de biomasa. En el Capítulo 2, se realizó un estudio comparativo de las 
técnicas de extracción utilizando la maceración como método de extracción tradicional, y el calentamiento por microondas y microondas combinado con presión como tecnología de intensificación del proceso de extracción convencional. El estudio mostró que la temperatura era el parámetro más importante para la extracción, y que era necesario extraer el aceite antes de la extracción de compuestos bioactivos ya que limitaba el acceso del disolvente a los extractivos. Como trabajo de futuro, se propone realizar el estudio utilizando otras tecnologias de intensificación como los ultrasonidos. También se recomienda poner a punto etapas de postratamiento para purificar los extractos.

Una vez obtenido el extracto, se estudió la formulación de los extractos para evitar su oxidación y desarrollar productos finales. La formulación se estudió con éxito en los capítulos 3 y 4. En el capítulo 3, se evaluó la impregnación de extractos en aerogeles de sílice por un método directo e otro indirecto. La tecnología de secado con $\mathrm{CO}_{2}$ supercrítico se aplicó como técnica para obtener productos sólidos y el proceso solgel se usó en la producción de aerogeles. Los resultados mostraron que, para el extracto de aceite, el porcentaje máximo obtenido fue del $58.6 \%$ cuando se aplicaron la impregnación indirecta y el secado al aire, y este porcentaje disminuyó al 15\% usando se utiliza secado por $\mathrm{CO}_{2} \mathrm{SC}$, debido a la extracción de los componentes del aceite durante el secado con $\mathrm{CO}_{2} \mathrm{SC}$. El rendimiento máximo de impregnación para el extracto polifenólico se logró con la impregnación indirecta y el método de secado mediante $\mathrm{CO}_{2} \mathrm{SC}$, alcanzando un valor de $16.4 \%$. El aumento de la concentración de extracto no produjo un mayor rendimiento de impregnación.

En el Capítulo 4, se ha estudiado la encapsulación de los extractos de semillas y de pulpa en una matriz polimérica mediante un proceso que utiliza $\mathrm{CO}_{2} \mathrm{SC}$ como antidisolvente (SAS), y el PVP se utilizó con éxito como agente encapsulante. Los experimentos en los que se empleó el extracto de las semillas como soluto y PVP como agente encapsulante, permitieron obtener resultados viables para las proporciones (1: 1), (2: 1) y (1: 2). Se consiguió la coprecitación, pero no se logró el recubrimiento de completo de los extractos. También se demostró la viabilidad de realiza el procesamiento del extracto de pulpa con PVP en diferentes proporciones. Durante el estudio de la formulación del extracto de semilla, se determinó la importancia de la relación sólido / líquido en la formación de partículas. Este parámetro no solo afecta la distribución del coprecipitado, sino que también implica el tamaño de partícula. El trabajo de futuro se recomienda el estudio de la eficacia de la encapsulación en el desarrollo de productos con base en los extractos obtenidos. Realizando estudios para su aplicación en el desarrollo 
de productos finales como la liberación de antioxidantes, pruebas de degradación con el tiempo y pruebas de cultivo celular para sus aplicaciones en productos cosméticos. 
Acknowledgements 


\section{Es imposible empezar los agradecimientos sin emocionarme}

En primer lugar me gustaría dar las gracias al Consejo Nacional de Investigación (CNPq) por la beca otorgada a través del programa Ciencia sin Fronteras que ha permitido la realización de este proyecto. También a los profesores del departamento de Ingeniería Química de la Universidad de Valladolid que me apoyaron en cada etapa de la investigación, especialmente a mis tutores Ángel Martín y María José Cocero por sus enseñanzas, ideas y sobre todo, por la oportunidad de llevar a cabo este proyecto en el grupo de procesos de alta presión. Especialmente me gustaría agradecerle a María José Cocero el no permitirme desistir cuando este momento parecía tan inalcanzable, gracias por el apoyo.

También me gustaría acordarme en estos agradecimientos del director del programa de Ingeniería Termodinámica de Fluidos, José Juan Segovia, por ser siempre tan solícito y del equipo técnico del laboratorio, especialmente José María, Isabel, Daniel y Araceli, cuya contribución a esta tesis fue esencial. No puedo olvidarme de mis queridos estudiantes, Edwin y Maira, ni de todos mis compañeros de doctorado (Marta, Maria A., Tijana, Victoria, Reinaldo, Sergio, Inês, Ana Najwa, Luismi, Mirian, Laura, Justin, Juan, Laura, Victoria, Sergio y entre muchos otros) con los que tuve el placer de coincidir y de compartir este período maravilloso (y muy duro); gracias por todas las enseñanzas que han sido muy importantes a lo largo de este viaje.

\section{A las personas maravillosas que conocí en esta aventura}

A todos mis queridos amigos, especialmente a Rodolfo, Erika, María P., Leonardo, Igor, Bruna, Priscilla, Grazi, Marta R., Alina, Sole, Ricardo, Thiago, Tijana, Marta F., y Ines, darles las gracias por los innumerables consejos, frases de motivación y tirones de orejas. Las risas compartidas en esta etapa desafiante de la vida académica también marcaron la diferencia. Mi eterna gratitud a todas las personas maravillosas que he conocido aquí "al otro lado del charco", y aunque alguno se me haya desperdigado por el mundo, os llevaré siempre presentes.

A mi familia

Dar las gracias a mi familia, que con su apoyo incondicional hace que todo parezca un poco más fácil. Gracias por entender mi ausencia en este periodo y por hacer todo lo posible para estar cerca, aun estando tan lejos. Merecen un especial agradecimiento mis padres, Sueli y Aparecido, mis tíos, Sergio y Mara, y mis queridos Guto, Evilene, Alice, 
Sofía y Caio. Gracias por llenar mi corazón de amor y esperanza. No sería posible seguir adelante si no hubieran sido siempre mi puerto seguro. No hay palabras en el mundo que puedan expresar lo agradecida que les estoy a todos ellos.

A Dios,

Agradezco a Dios que en su infinita misericordia puso en mí la fuerza necesaria para llegar hasta aquí. 


\section{É impossível começar estes agradecimentos sem me emocionar.}

Gostaria de iniciar agradecendo ao Conselho Nacional de Pesquisa (CNPq) pela bolsa de estudo concedida através do programa Ciências sem Fronteiras e aos professores do departamento de Engenharia Química da Universidade de Valladolid que apoiaram cada etapa deesta pesquisa, especialmente aos meus orientadores Ángel Martín e María José Cocero pelos ensinamentos, ideias aportadas e pela oportunidade de realizar este projeto no grupo de processos a alta-pressão. Agradeço especialmente a María José Cocero por não me deixar abandonar quando este momento me parecia tão inatingível, obrigada pelo incentivo e apoio.

Agradeço também ao diretor do programa de Engenharia termodinâmica de fluidos, José Juan Segovia por sempre ser tão solícito e a equipe técnica do laboratório, em especial a José María, Isabel, Daniel e Araceli cujo aporte a esta tese foi essencial. Também sou imensamente grata aos meus queridos estudantes, Edwin e Maíra e a todos os companheiros de doutorado (Marta, Maria A., Tijana, Victoria, Reinaldo, Sergio, Inês, Ana Najwa, Luismi, Mirian, Laura, Justin, Juan, Laura, Victoria, Sergio, entre tantos outros) com os quais tive o prazer de compartilhar este período maravilhoso (e duríssimo), obrigada por todos os ensinamentos vocês foram muito importantes durante toda esta aventura.

\section{Às pessoas maravilhosas que conheci nesta jornada}

Só tenho a agradecer a todos meus queridíssimos amigos, especialmente à Rodolfo, Erika, María P., Leonardo, Igor, Bruna, Priscilla, Grazi, Marta R., Alina, Sole, Ricardo, Thiago, Tijana, Marta F. e Ines. Obrigado pelos inúmeros conselhos, frases de motivação e puxões de orelha. As risadas que vocês compartilharam comigo nessa etapa tão desafiadora da vida acadêmica também fizeram toda a diferença. Minha eterna gratidão. A todas as pessoas maravilhosas que conheci aqui "al otro lado del charco", e ainda que alguns tenham se perdido pelo mundo sempre estarão presentes.

\section{À família}

Gostaria de agradecer também a minha família que com seu apoio incondicional fez e faz tudo parecer um pouquinho mais fácil. Obrigado por entenderem minhas ausências e fazerem todo o possível para estarem perto mesmo estando tão longe. Principalmente, meus sinceros agradecimentos aos meus pais, Sueli e Aparecido, aos meus tios, Sérgio e Mara, aos meus queridíssimos Guto, Evilene, Alice, Sofia e Caio. Obrigada por encherem meu coração de amor e esperança, não seria possível seguir em 
frente se vocês não fossem o meu porto. Não há palavras no mundo que possam expressar o quão grata sou a todos eles.

\section{À Deus}

Agradeço a Deus que em sua infinita misericórdia colocou em mim a força necessária para chegar até aqui. 
About the Author 
Rafaella Theodoro Buratto (Campinas, 1990) started the studies of chemistry at the Pontifical Catholic University of Campinas in 2009.

Ms. Buratto had her first approaching with $R \& D$ in 2010. She has been in touch to this area since then, being working in many different fields, such as catalytic oxidation (PUC-Campinas), genetic improvement (IAC), vehicular engines combustion (Magneti Marelli-Powertrain), extraction and formulation of natural products (HPP Group), and development of methods for HPLC (PUC-Campinas) and GC (EMS Sigma Pharma). In the academic course of 2012-2013, she spent ten months at University of Valladolid (UVa) for the development of the final project 'Encapsulation of Quercetin by Precipitation in Supercritical Anti-solvent (SAS)' in the frame of the program 'Ciencias sem Fronteiras'. At her return from Spain, she graduated at the end of 2013 and joined EMS Sigma Pharma at the beginning of 2014 as Analytical Researcher.

Ms. Buratto starts her MSc studies on nanostructured materials for nanotechnology applications at the University of Zaragoza, in the academic course 2014201 after concluding hare final master Project 'Stimuli-Responsive Polymeric Nanoparticles for Controlled Release of Cargo Molecules'. More recently, she initiated her Ph.D. in Chemical Engineering and Environmental Technology, in 2016, at the HighPressure Processes Group of the Department of Chemical Engineering (University of Valladolid). The thesis is concluding in 2019, named as 'Valorization of Euterpe Oleracea Mart. (açaî) by-product: Characterization, extraction, and Formulation'. 


\section{Scientific Publications and Communications in Congresses}

2019 - Poster Communication: V Iberoamerican Conference on Supercritical Fluids: 'Encapsulation of Euterpe Oleracea Mart. (Açaí) Residue Extracts By Sas Process'.R. Buratto, M.Chinchilla, Á. Martín, and M J. Cocero.

2019 - Scientific Publication: Journal Of Supercritical Fluid: 'Impregnation of açaí residue extracts in silica-aerogel '. R. Buratto, E.G. Holes, Á. Martín, and M J. Cocero.

2018 - Oral Communication in Congress: International Symposium on Supercritical Fluids 2018 Antibes-Juan-les-Pins (France): 'Impregnation of Açaí Residue Extracts in Silica-Aerogel '.: R. Buratto, E.G. Holes, Á. Martín, and M J. Cocero.

2018 - Oral Communication: Meeting of Young Ibero-American Investigators: 'Extraction and Formulation of phytochemicals from Açaí (E. Oleracea mart.) Residue to Cosmetic Application by nonpolluting technology'. R. Buratto, E.G. Hoyos, Á. Martín, and M J. Cocero.

2018 - Oral Communication: UVa Researcher in the Adventure of Science and Technology: 'Use of waste from the processing of Acai (E. Oleracea mart.) In cosmetics'. R. Buratto, E.G. Holes, Á. Martín, and M J. Cocero.

2017 - Poster Communication: 10th World Congress of Chemical Engineering (WCCE 10): 'Polyphenol Extraction From Açaí Residue by Microwave-Assisted Extraction (MAE)'. R. Buratto, Á. Martín, and M J. Cocero.

2016 - Oral Communication: European Summer School in High-Pressure Technology: 'Development, Extraction, and Improvement of Phytochemicals for Dye Applications by Non-Polluting Technology'. R. Buratto, Á. Martín, and M J. Cocero.

2014- Scientific publication: Industrial \& Engineering Chemistry Research: 'Enhanced Delivery of Quercetin by Encapsulation in Poloxamers by Supercritical Antisolvent Process'. M. Fraile, R. Buratto, B. Gómez, Á. Martín, and M J. Cocero. 
Attendance to Congresses, Conferences, and Courses

2019 - Congress attendance: V Iberoamerican Conference on Supercritical Fluids PROSCIB. Campinas, Brazil. September 02- 06, 2019.

2019 - Congress attendance: Meeting of Ibero-American Researchers. Tordesillas, Spain. March 22, 2018.

2019 - Conference attendance: Researchers of the University of Valladolid in the Adventure of Science and Technology. Valladolid, Spain. April 04-05, 2018.

2019 - Course Attendance: 'Basic Course of Analysis by Gas Chromatography'. Valladolid, Spain. February 14 - 21, 2019.

2018 - Course Attendance: 'English Course for Ph.D. students - Level C1'. Valladolid, Spain. April 16 - June 18, 2018.

2018 - Congress attendance: International Symposium on Supercritical Fluids 2018. Antibes-Juan-les-Pin, France. April 22-25, 2018.

2018 - Congress attendance: Meeting of Ibero-American Researchers. Tordesillas, Spain. April 13, 2018.

2018 - Conference attendance: Researchers of the University of Valladolid in the Adventure of Science and Technology. Valladolid, Spain. March 02, 2018.

2017- Course Attendance: 'Basic HPLC Liquids Chromatography Analysis Course'. Valladolid, Spain. November 22 - 30, 2017.

2017- Attendance to Congress: 10th World Congress of Chemical Engineering. Barcelona, Spain. October 1 - 5, 2017.

2017- Course Assistance: 'Deactivation and Activation of Heterogeneous Catalysis Through Carbon Deposition'. Valladolid, Spain. November 09-10, 2017.

2017- Course Assistance: 'Winesense - Potential Commercial applications of Grape extract'. Matarromera (Valbuena del Duero) Valladolid, Spain. June 21 - 22, 2017.

2017- Research Day of the School of Industrial Engineering. The University of Valladolid, Faculty of Industrial Engineering. May 19, 2017 
2017- Course Assistance: 'New on the Web of Science'. Valladolid, Spain. February 06, 2017.

2016- Course Assistance: 'Bioproducts Engineer and Biorefineries'. Valladolid, Spain. June $14-17,2016$.

2016- Course Assistance: 'CO2 Utilization as a C 1 feedstock and Solvent in catalysis'. Valladolid, Spain. October 6 - 7, 2016.

2016- Course Assistance: 'Matlab Academic Tour 2016'. Valladolid, Spain. April 7, 2016.

2016- Course Assistance: 'European Summer School in High-Pressure Technology. Graz-Maribor. July 3 -17, 2016.

2016- Course Assistance: 'Wiley - How to get published in international journals'. Valladolid, Spain. September 27, 2016.

2016- Course Assistance: 'Winesense spring school'. Valladolid, Spain. April 18 - 22, 2016.

2016 - Opening Day Course 2016/17. The University of Valladolid, Faculty of Industrial Engineering. December 1, 2016 
